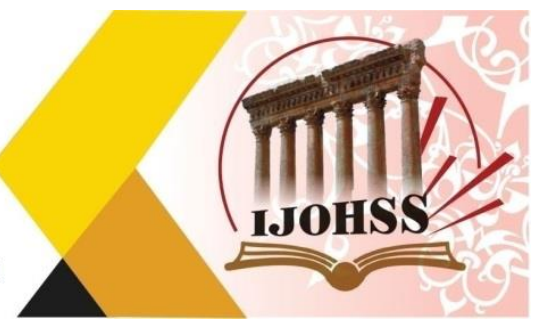

\title{
دور نظام المعلومات المحاسبية الإلكترونية في تعزيز أمن المعلومات المالية المدية \\ (دراسة تطبيقية في شركة بردبار للصرافة فرعات محافظة اربيل 2021)
}

\author{
راميار رازكار احمد \\ قسم المحاسبة والمالية المالية \\ كلية الإدارة و الاقتصاد الفية والية \\ الجامعة اللبنانية الفرنسية الأصناد \\ اربيل - إقليم كردستان - العراقية الفينان
}

ramear.walzy12@gmail.com البريد الاككتروني:

\begin{abstract}
الملخص

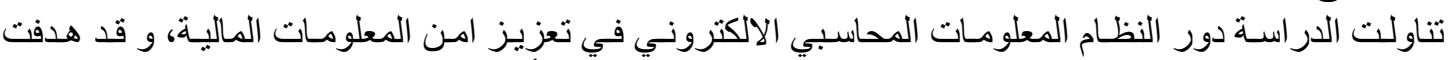

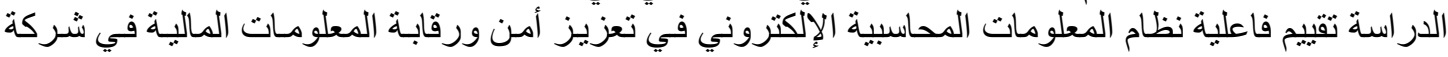

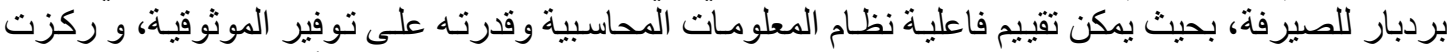

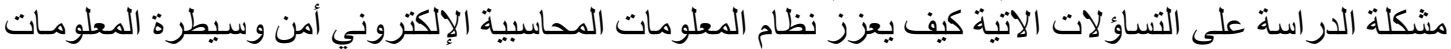

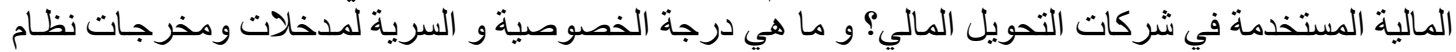

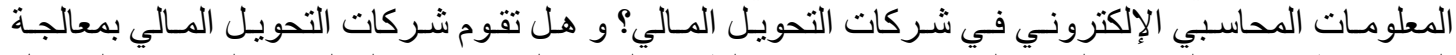

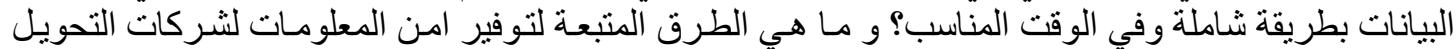

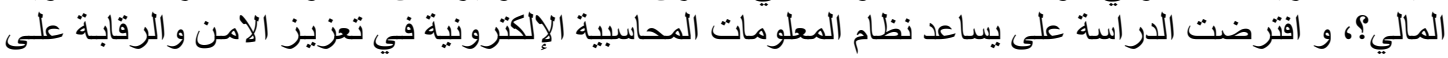

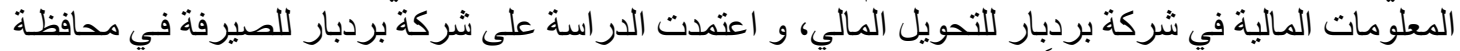

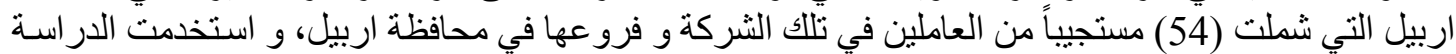

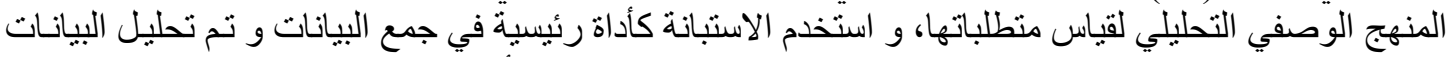

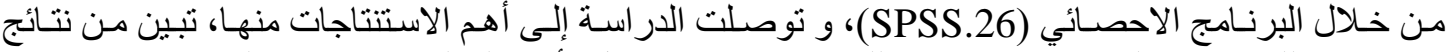

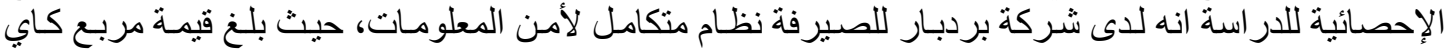

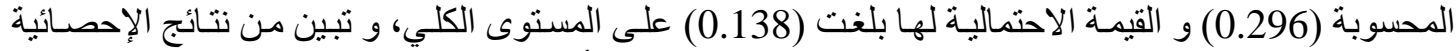

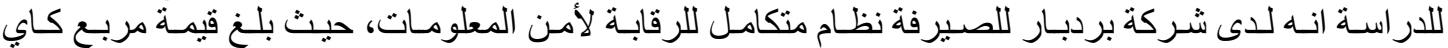

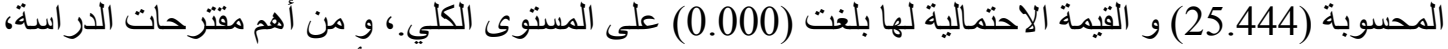

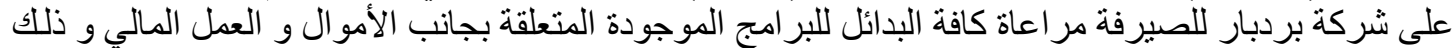

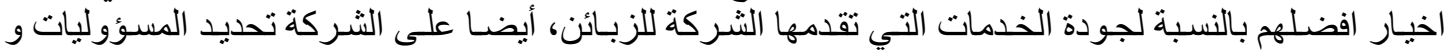

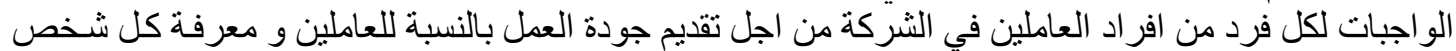
الواجبات و المسؤوليات الو اجبة على عاتقه في الثركة.
\end{abstract}

الكلمات المفتاحية: نظم المعلومـات، نظـام المحاسبي الالكتروني، نظسام المعلومـات المحاسبي، امن المعلومـات، شركات الصبرفة. 


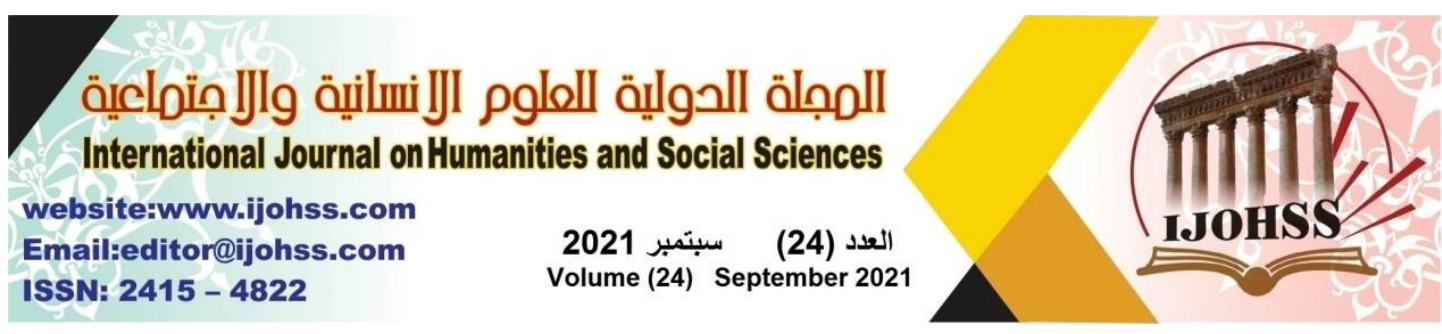

\title{
The Role of the Electronic Accounting Information System in Enhancing the Security of Financial Information
}

(An applied study in Bardabar Exchange Company، Erbil Governorate Branch، 2021)

\author{
Ramyar Rzgar Ahmed \\ Department of Accounting and Finance, College of Administration and Economics, \\ Lebanese French University, Erbil, Kurdistan Region, Iraq \\ Email: ramear.walzy12@gmail.com
}

\begin{abstract}
The study dealt with the role of the electronic accounting information system in enhancing the security of financial information، and the study aimed to evaluate the effectiveness of the electronic accounting information system in enhancing the security and control of financial information in the Bradabar Banking Company" so that the effectiveness of the accounting information system and its ability to provide reliability can be evaluated. On the following questions: How does the electronic accounting information system enhance the security and control of financial information used in money transfer companies? What is the degree of privacy and confidentiality of the inputs and outputs of the electronic accounting information system in the money transfer companies? Do money transfer companies process data in a comprehensive and timely manner? What are the methods used to provide information security for money transfer companies ?; The study assumed that the electronic accounting information system would help in enhancing the security and control of financial information in the Bradbar Financial Transfer Company، and the study relied on the Bradabar Exchange Company in Erbil Governorate، which included (54) Responding to the employees of that company and its branches in Erbil Governorate، and the study used the descriptive and analytical method to measure its requirements، and used the questionnaire as a main tool in data collection and the data was analyzed through the statistical program (SPSS.26) ' and the study reached the most important conclusions from it. From the statistical results of the study، it was found that the Bradabar Exchange Company has an integrated system for information security، where the calculated value of the chi-square reached (0.296) and its probability value amounted to (0.138) at the aggregate level، and it was found from the statistical results of the study that the company had an integrated system For the control of information security، where the calculated value of the chi square reached $(25.444)$ and its probability value amounted to (0.000) at the aggregate level. And among the most important proposals of the study، Bradabar Banking should consider all alternatives to the program. C) The existing ones related to the side of money and financial work ' and that is the best choice for them with regard to the quality of services provided by the company to the customers، also the company must define the responsibilities and duties of each member of the company's employees in order to provide the quality of work for the workers and to know each person's duties and responsibilities It is his responsibility in the company.
\end{abstract}

Keywords: information systems` electronic accounting system ‘ accounting information system، information security، banking companies. 
منذ ظهورة البشر الأوائل إلى اليوم، شهـ العالم العديد من التغييرات، ومع مرور الوقت، تتطور أيضًا أساليب

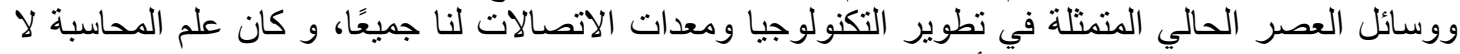

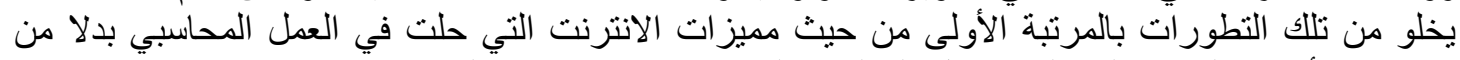

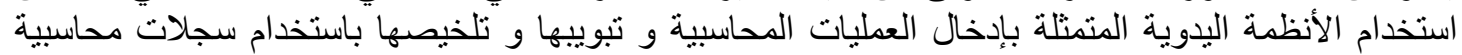

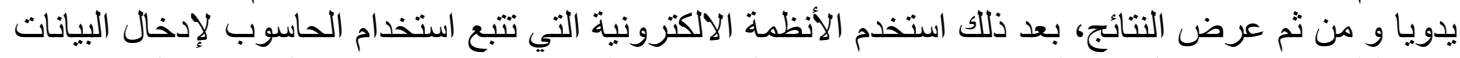

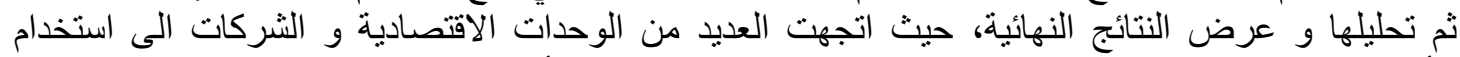

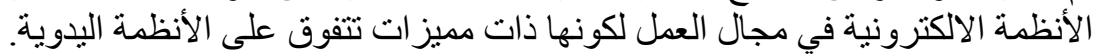

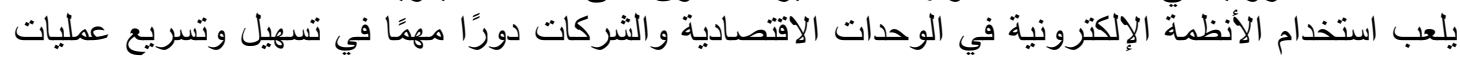

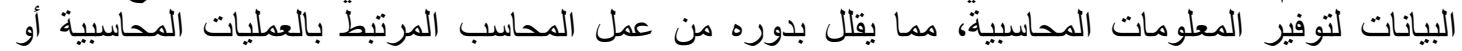

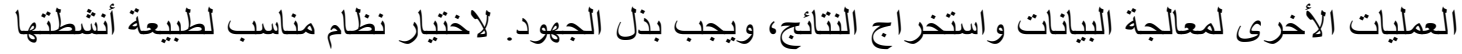

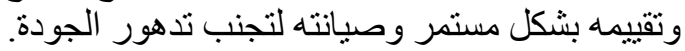

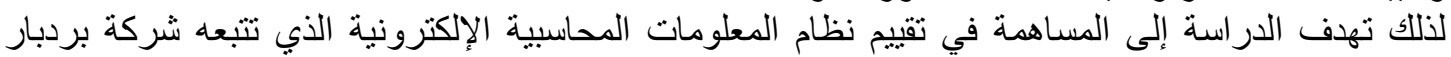

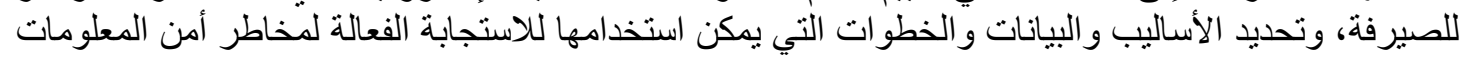

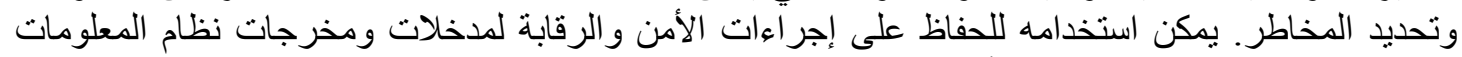

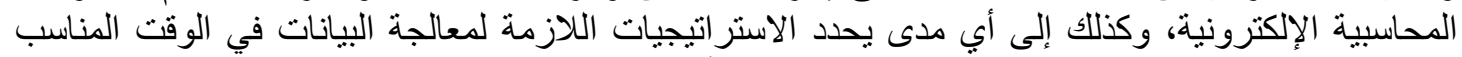

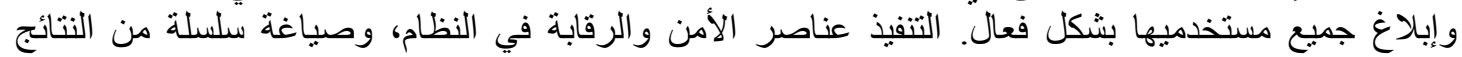

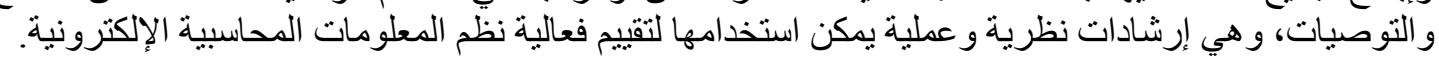

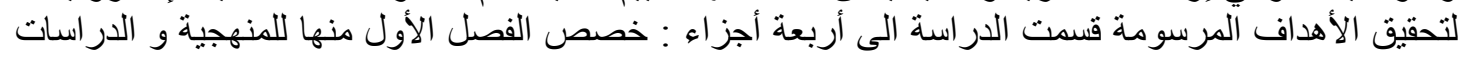

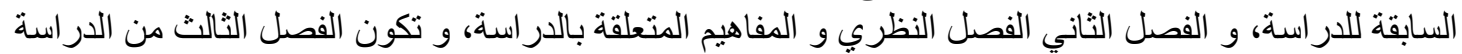

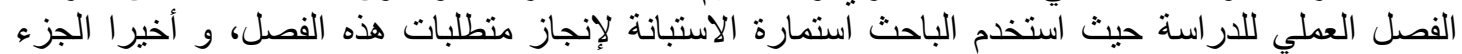

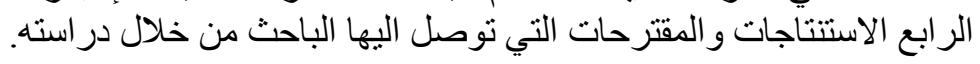

\section{الفصل الأول: الإطار المنهجي للاراسة}

مشكلة الاراسة

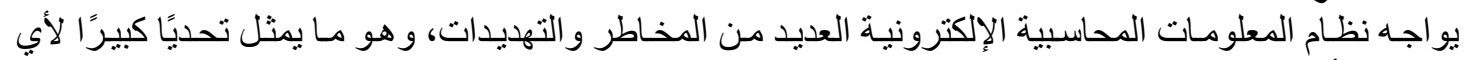

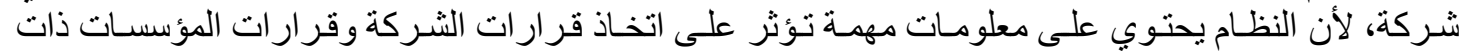

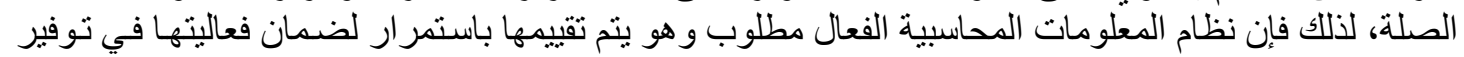

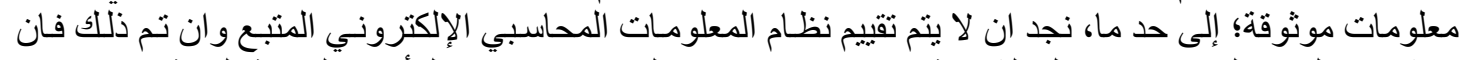

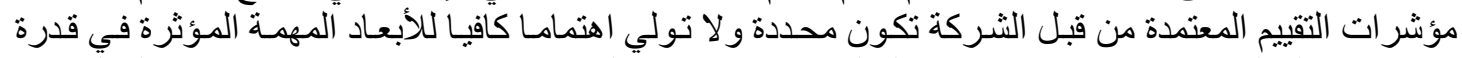

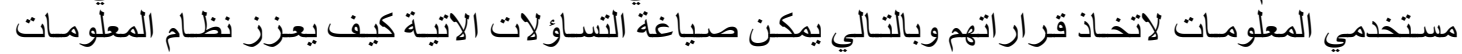

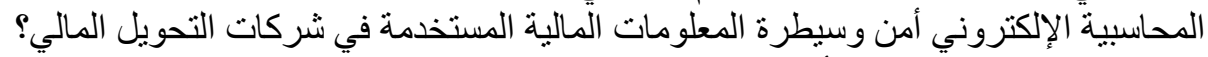

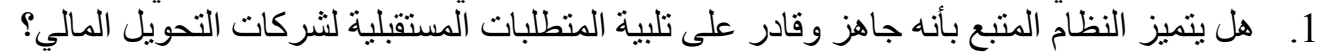

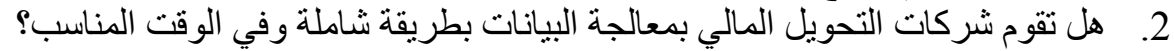

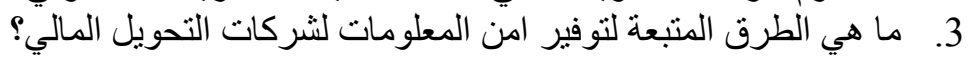

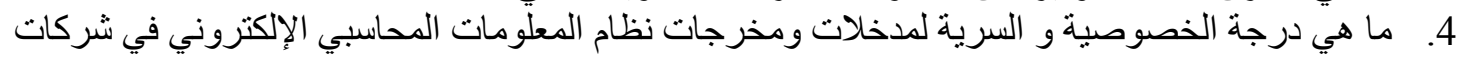

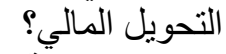
اهداف الار استة: تسعى الدراسة الى تحقيق الأهداف الاتية:

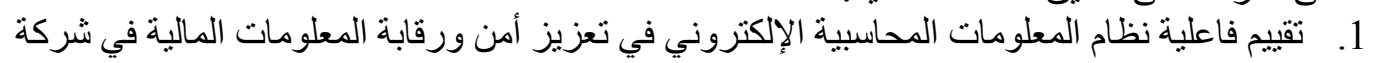

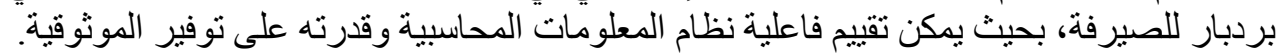

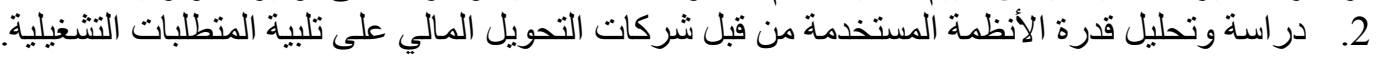




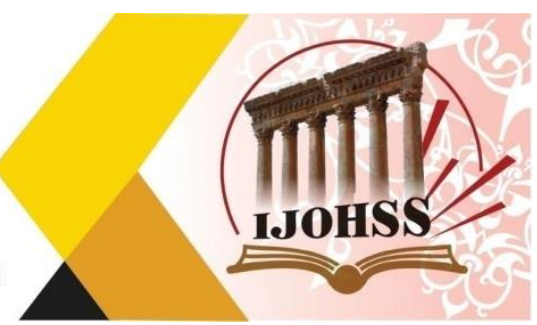

3. تحديد الاستر اتيجيات اللازمة لمعالجة البيانات في الوقت المناسب و الابلاغ عنها بشكل فعال لجميع

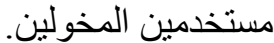
4. تحديد الأساليب والإجر اءات التي يمكن استخدامها للاستجابة بفعالية لمخاطر أمن المعلومات.

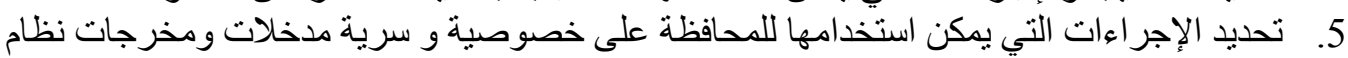
ألمعلومات المحاسبي الإلكتروني في شركة بردبة الإسبار للصبيرفة.

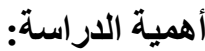
الأهمية المهنية للاراسة

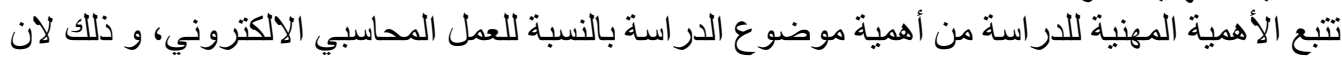

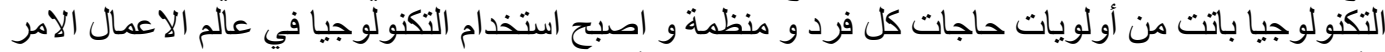

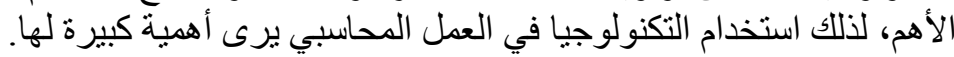

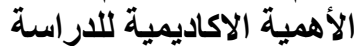

تتبع أهمية الدر اسة من البيئة المحاسبية الحالية، و يمكن تلخيص أهمية الدر اسة بالنقاط الاتية:

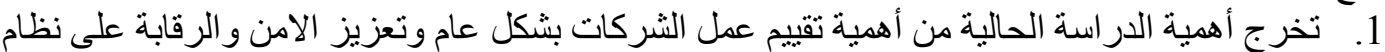
المعلومات المحاسبي الالكتروني المطبة المبن.

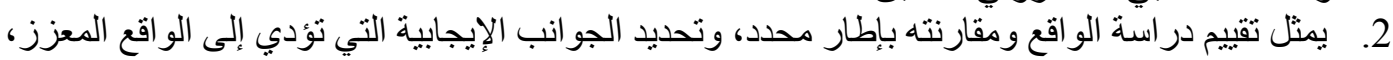

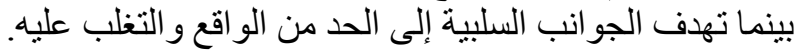

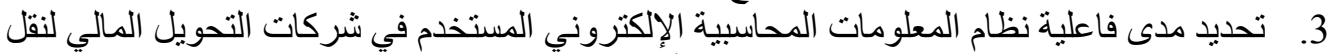

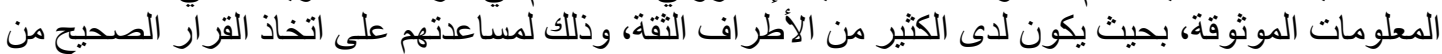
جهة وتطوير نظام المعلومات المحاسبية المطبق على الجانب الآخر.

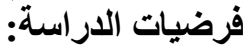

لغرض الإجابة عن تساؤلات الدر اسة فان الدراسة تقوم على فرضية الرية رئيسة الاتية:

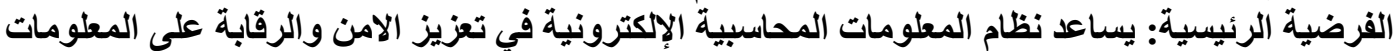

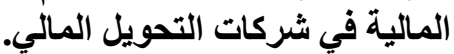

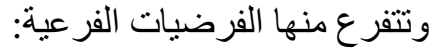

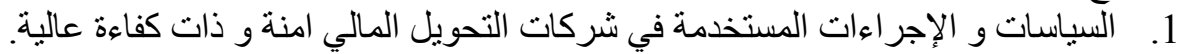

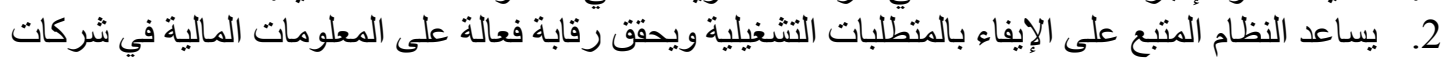

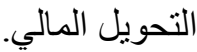
وسائل جمع البيانات و المعلومات:

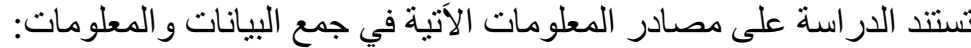

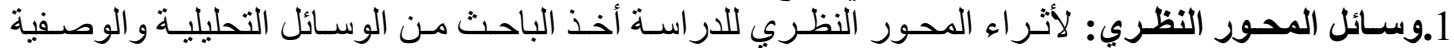

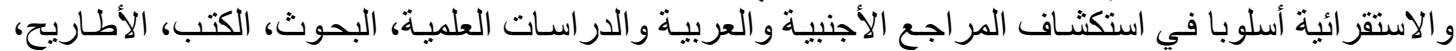

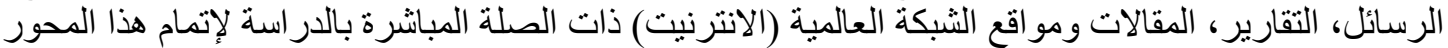

2.وسائل المحور التطبيقي: لأثراء هذا المحور من الدراسة أعتمد الباحث على استمارة الاستبانة باعتبار هـا أداة

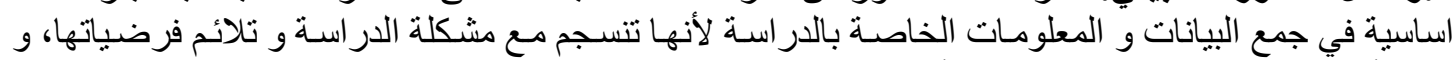

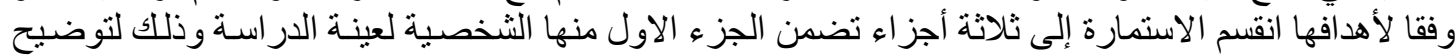

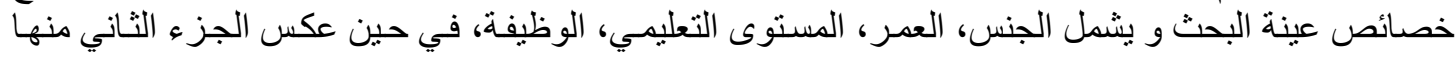

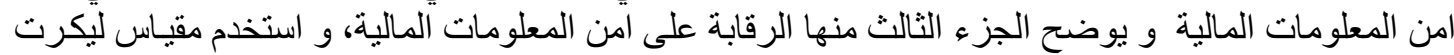

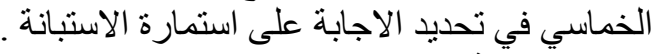

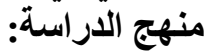

استندت الدر اسة على المنهجين الاستقر ائي و الاستتباطي في اتمام مضامين و معالجة مشكلاتها و التأكد من فرضياتهاو تحقيق أهدافها. 


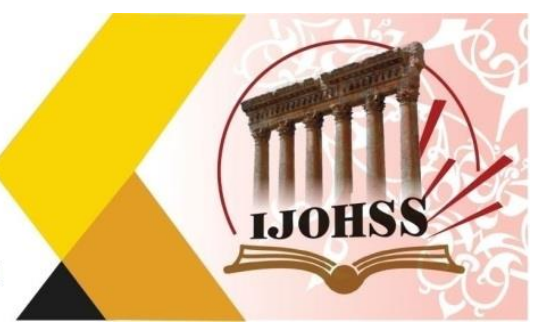

اختبارات صحة أداة الاراسة: الاست

أجريت الاختبار ات الآتبة لتحقيق من صحة الدارة أداة الدر اسة: 1. اختبار صحة محتوى الاراسة: اخضعت الإستبنة الاستبانة لاختبار الاتساق الخارجي لتحقيق من صحة محتو اها

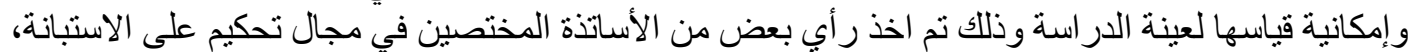

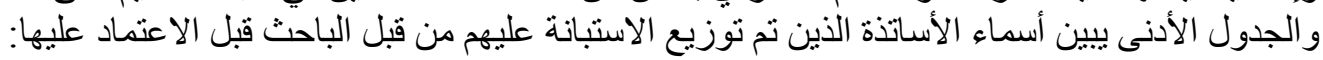

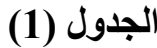

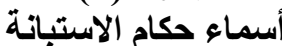

\begin{tabular}{|c|c|c|c|}
\hline الجامعة & التخصص & الاسم & الرقم \\
\hline جامعة الموصل & الإدارة الاستراتيجية & أ.د. معن و عدالله المعاضيدي & 1 \\
\hline جامعة الموصل & المحاسسبة & أ.م.د. علي مال الله عبدالله & 2 \\
\hline جامعة الموصل & محاسبة التكاليف & أ.م.د. خالا غازي التيمي & 3 \\
\hline جامعة الموصل & الاحصاء & أ.م.د. محمد عبدالرزاق الناصر & 4 \\
\hline جامعة الموصل & الاحصاء & أ.د. بسام اليوزبكي & 5 \\
\hline
\end{tabular}

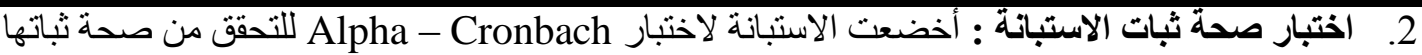

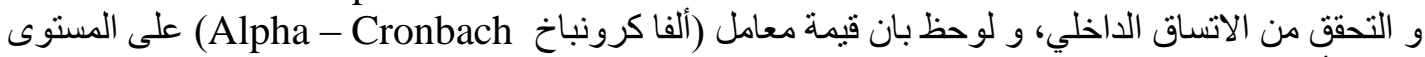

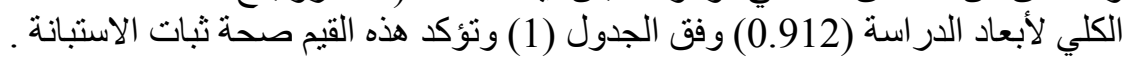

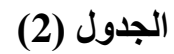

اختبار ألفا كرونباخ لمتغير (2) اتلات الدراسة

\begin{tabular}{|c|c|c|c|}
\hline Alpha - Cronbach & عدد العبار ات & متغيرات الاراسة & $ت$ \\
\hline 0.925 & 20 & امن المعلومات المالية & 1 \\
\hline 0.899 & 13 & الرقابة على امن المعلومات المالية & 2 \\
\hline 0.912 & 33 & القيمة الكلية للاستبانة & 3 \\
\hline
\end{tabular}

المصدر : من اعداد الباحث بالاعتماد على مخرجاته لاته البرنامج الاحصائي SPSS.

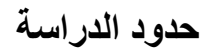
1. الحدود العينة : تتكون من العاملين في فرع شركة بردبار للصبرفة في محافظة أربيل. 2.

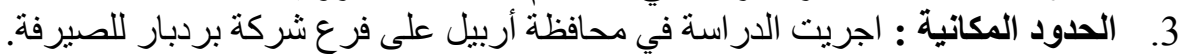
4. الحدود الزمانية : سنة المانة اجرود 2021 .

الاراسات السابقة در اسة المطيري و لبيسفي سنة ،202 بعنوان دور أنظمة المعلومات المحاسبية الالكترونية في الحد من مخاطر

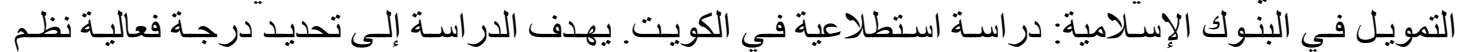

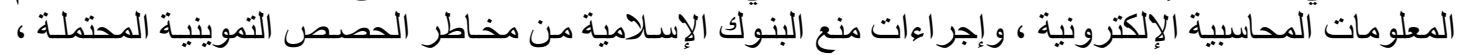

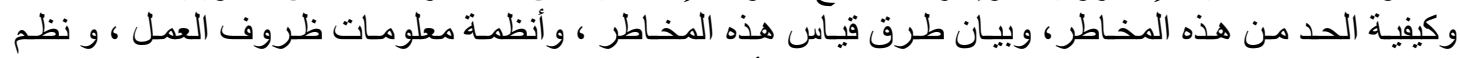

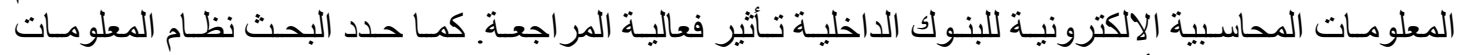

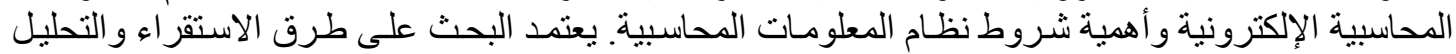

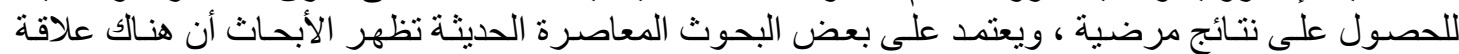

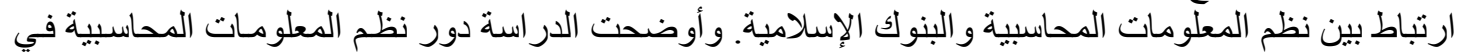

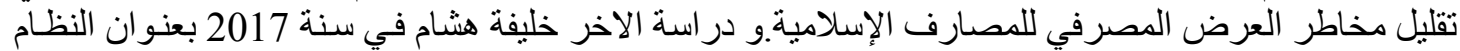

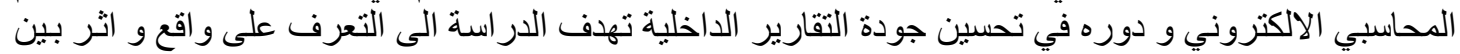




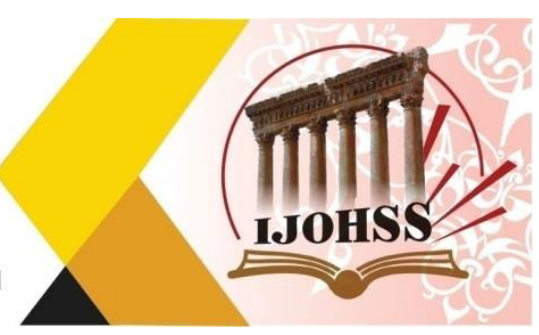

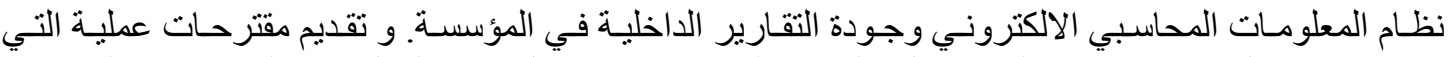

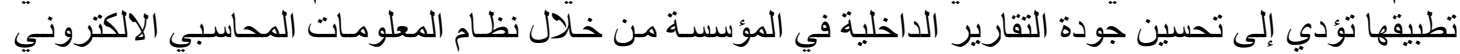

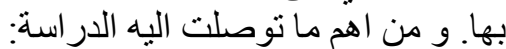

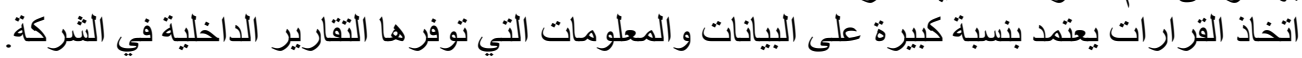

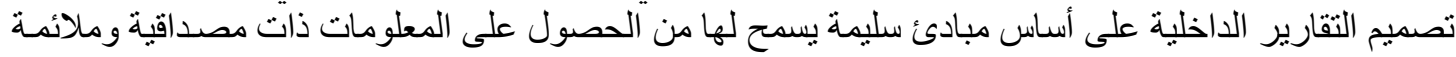

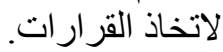
استخدام الكمبيوتر في معالجة اليبانات المحاسبية يعد خطوة مهمة لكفاءة إنتاج و استهلاك المعلومـات المحاسبية

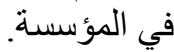

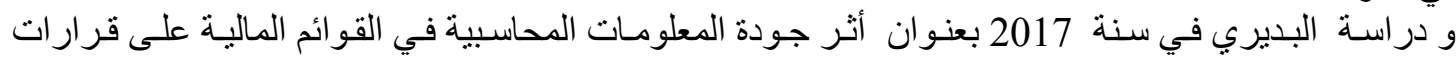

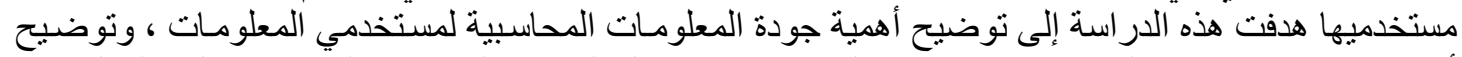

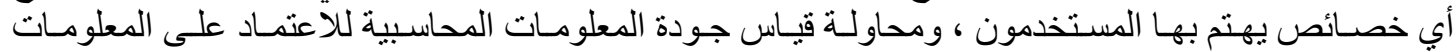

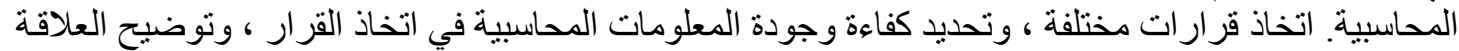

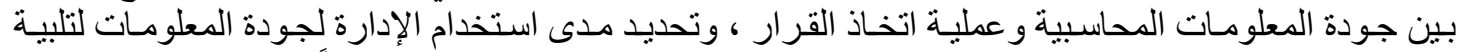

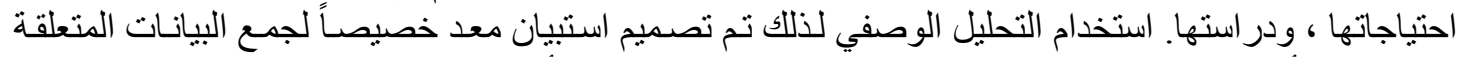

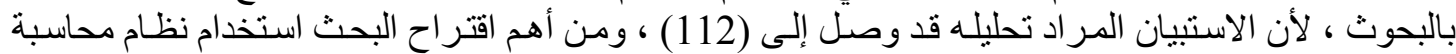

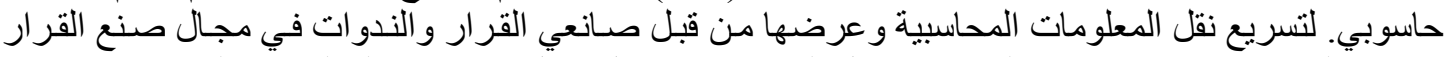

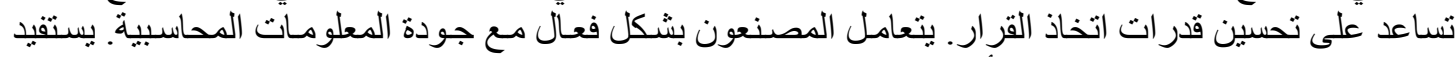

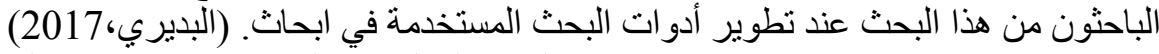

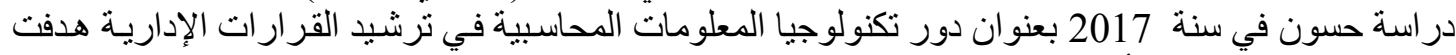

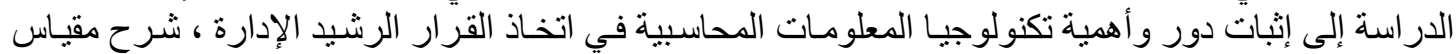

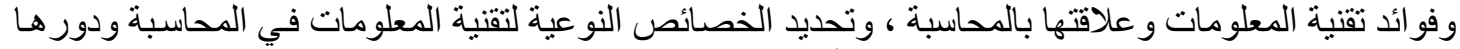

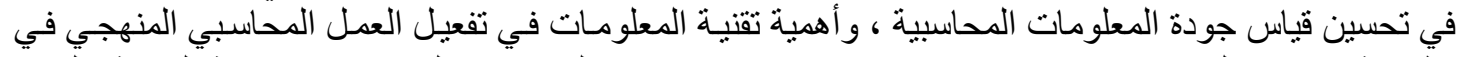

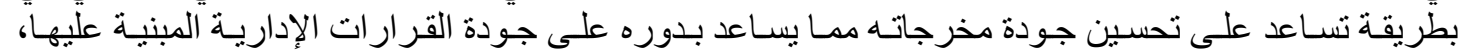

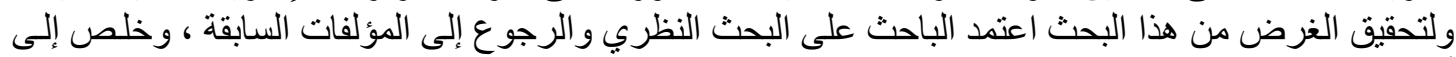

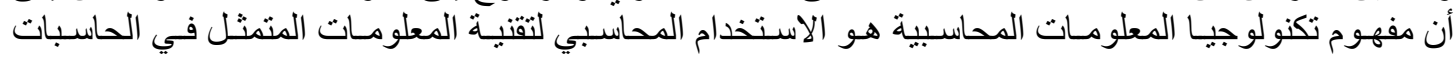

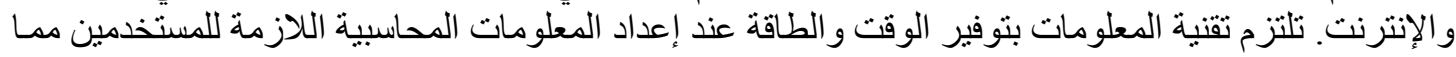

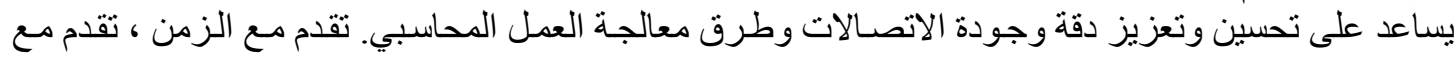

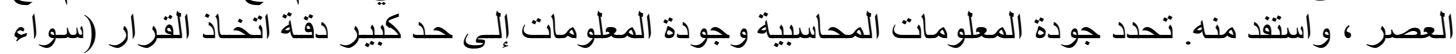

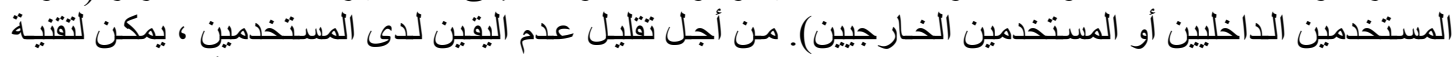

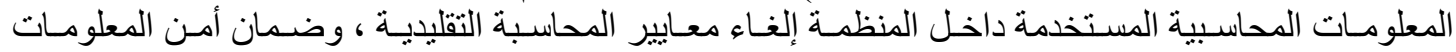

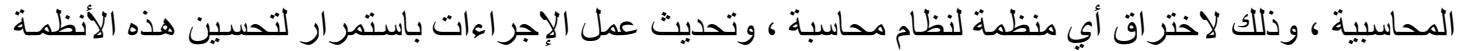

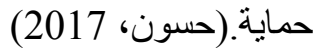

Francis,\&Olayemi Accounting Information System As Aids اما در اسات الأجنبية مثل در استة To Managerial Performances.

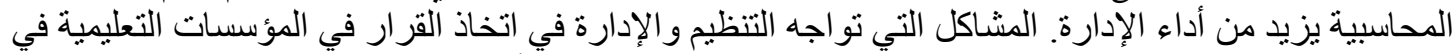

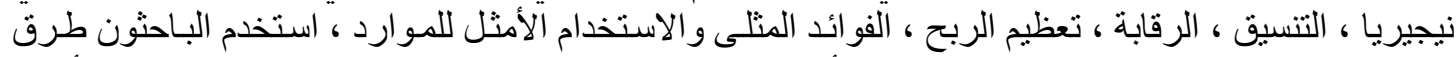

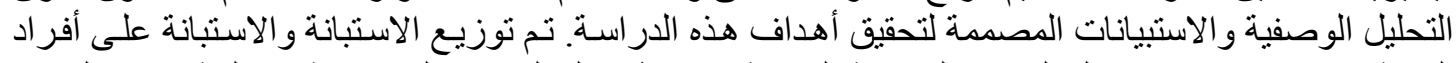

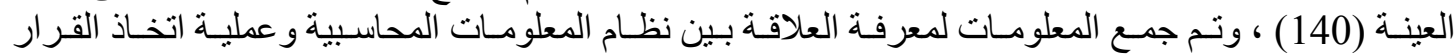

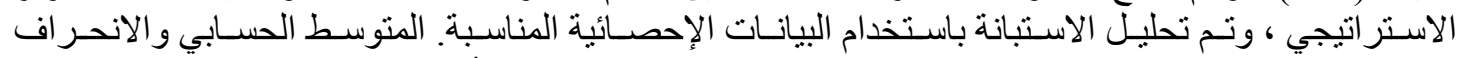

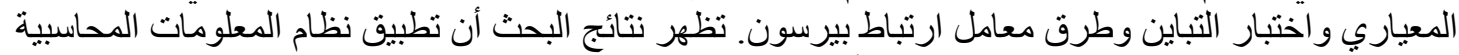

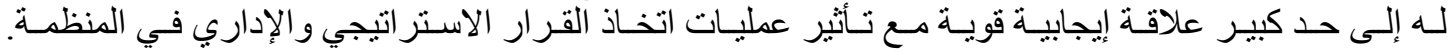

(Francis,\&Olayemi 2016) 


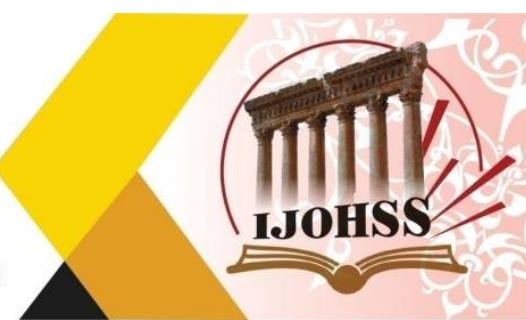

The Role Of Accounting Information Systems In الاخخر Swalha, 2014) دراسـة Administrative Decision-Making (Field Study) Jordanian Banks Rationalized

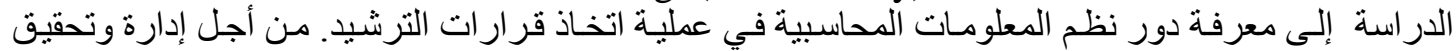

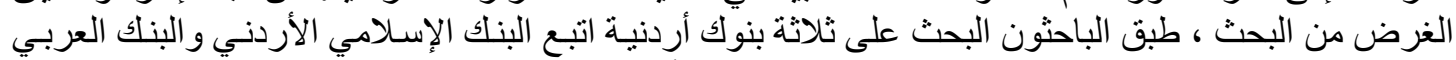

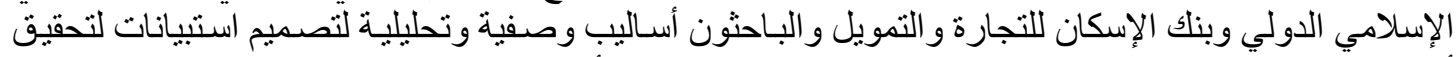

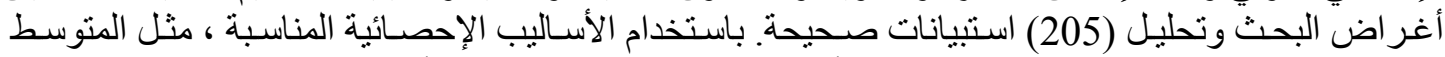

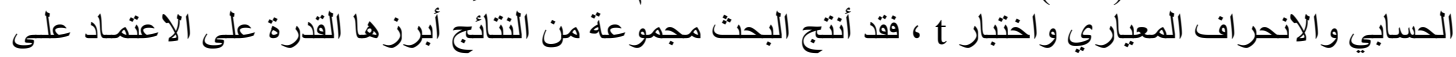

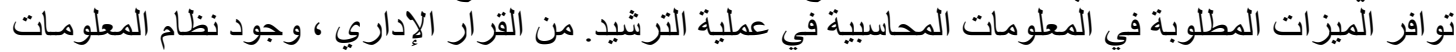

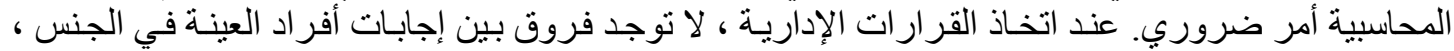

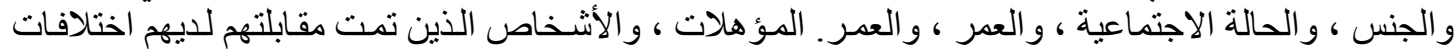

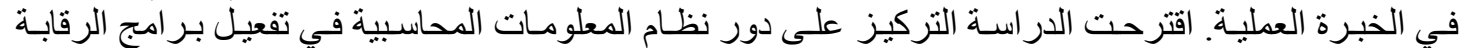

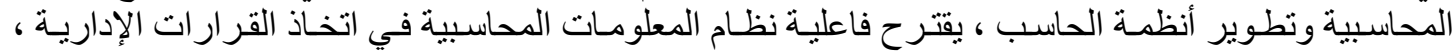

ومقارنتها مع التوقعات المستقبلية. (Swalha, 2014)

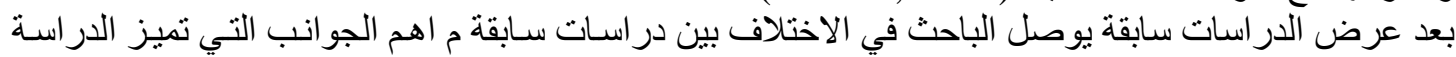
الحالية عن الدراسات السابقة هي كالاتي:

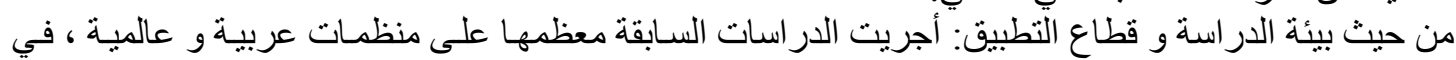

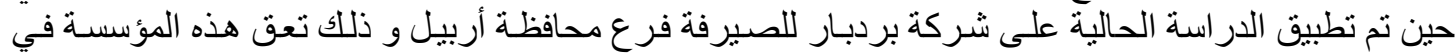

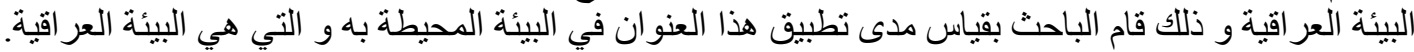

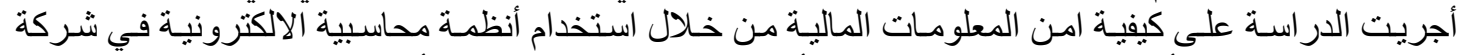
بردبار للصيرفة فرع أربيل، و ذللك لان استخدام الأنظمة المحاسبية الالكترونيـة أصبحت من المواضيع الحديثة في السنو ات الخمس الاخيرة. من حيث هدف الدراسة ركزت الدراسة الحالية على قياس دور الأنظمة المحاسبية الالكترونية في امن المعلومات المالية و تحقيق السرية في شركات التحويل المالي في البيئة العر اقية.

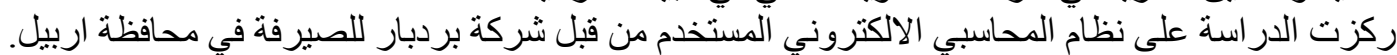

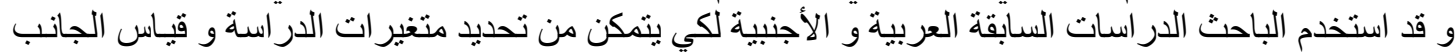

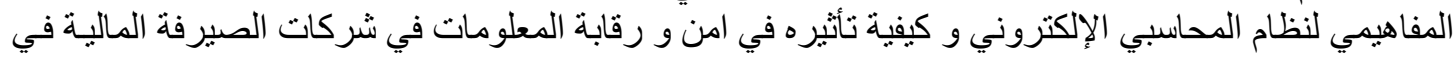

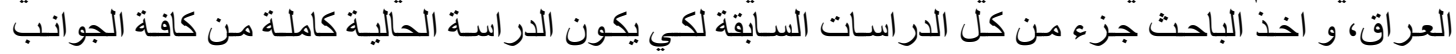
الاكاديمية و العلمية.

\section{الفصل الثاني: الاطار النظري للاراسة}

متطلبات الامن والرقابة على نظم المعلومات المحاسبية الاكترونية الأول: متطلبات الامن على المعلومات المحاسية الماتيبة الإكترونية

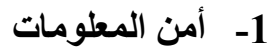

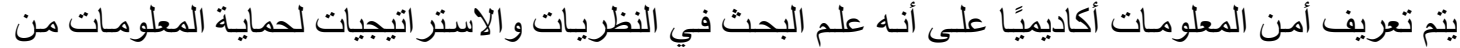

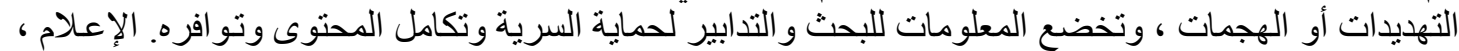

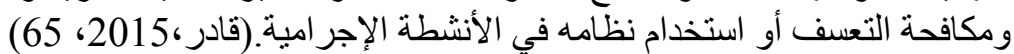

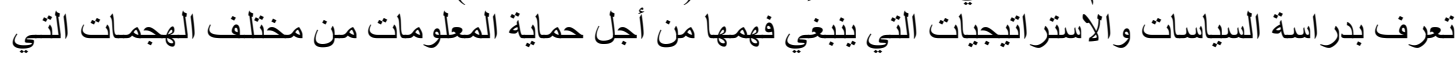

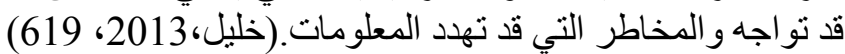

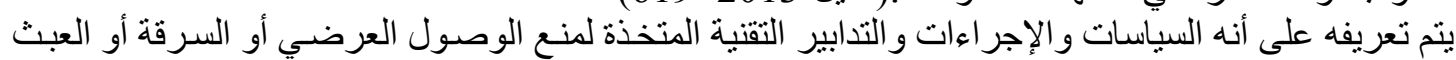

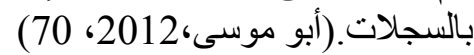

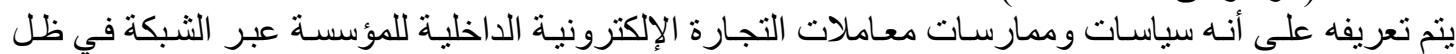

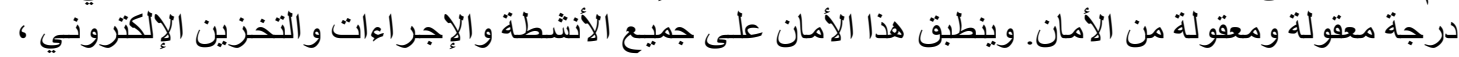




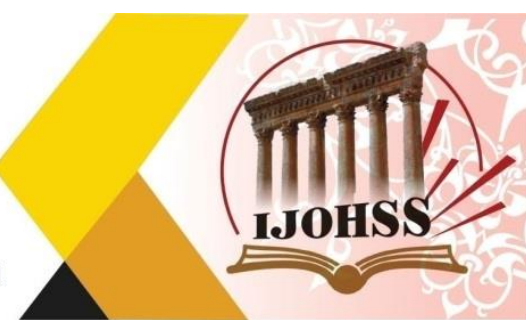

وكذللك الثركات التجاريـة و العملاء و الهيئات التنظيميـة والأوصياء و المحتمل أي شخص آخر معرض لخطر الإيلاج.)(Marshal\&Stembart,2009,11) يتم تعريفها على أنها حماية جميع الموارد المستخذمة في معالجـة المعلومـات ، لأن المنظمــة نفسـها و الأفر اد فيها

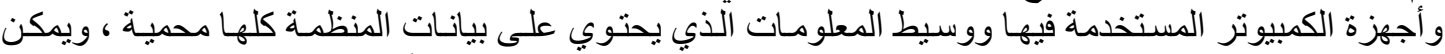

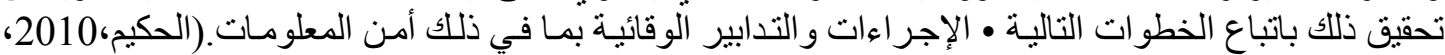

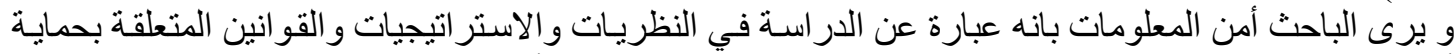

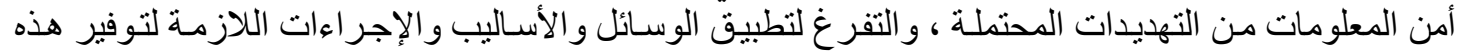

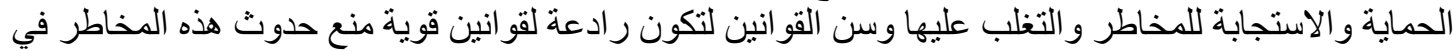

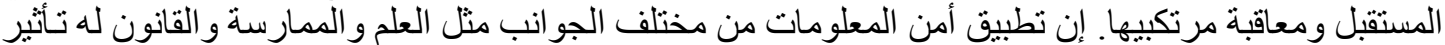
كبير في زيادة ثقة الناس في نظام المعلومات المنات المحاسبية.

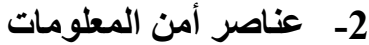

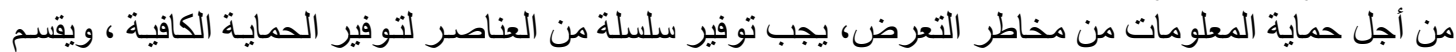

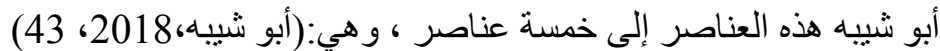

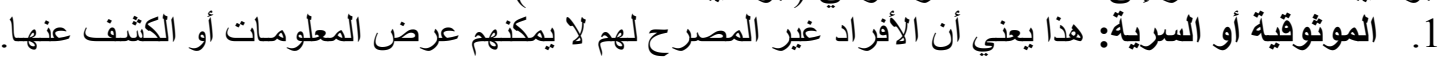

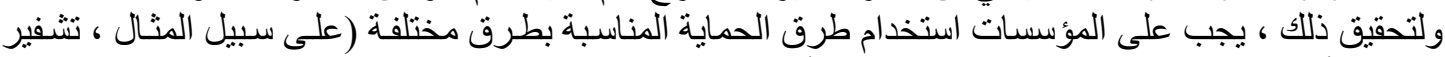

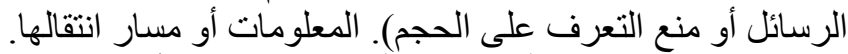

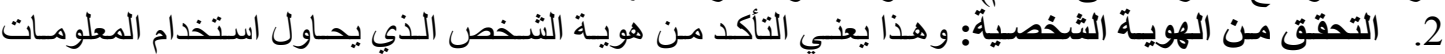

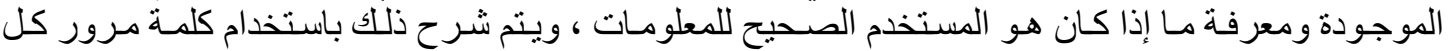

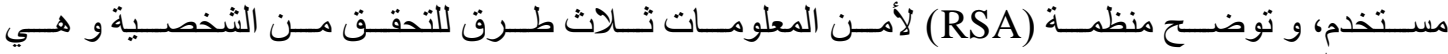

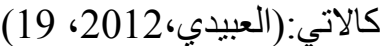

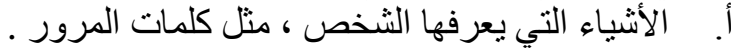

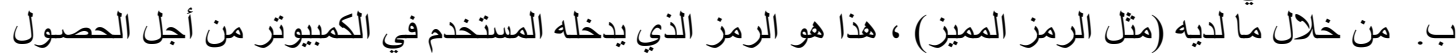

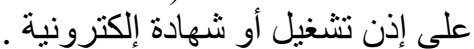

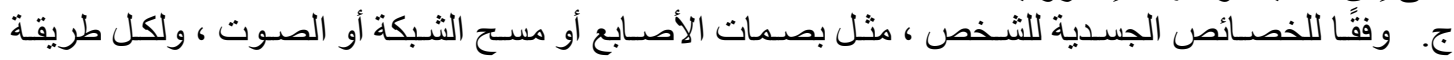

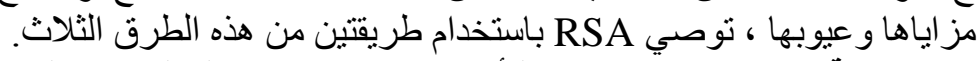

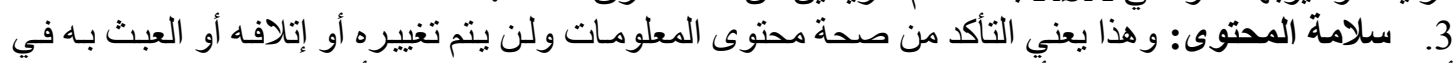

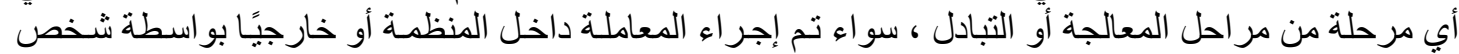

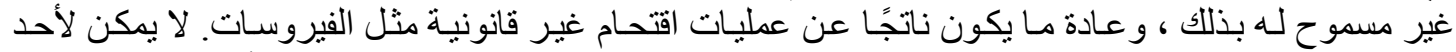

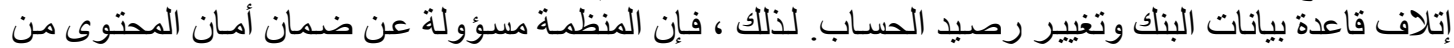

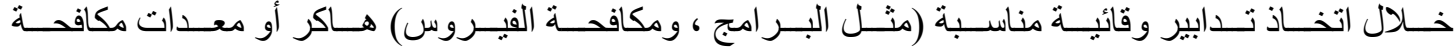

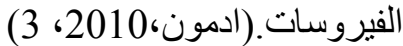

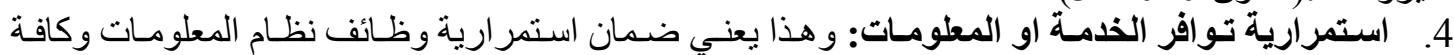

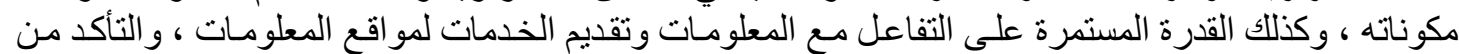

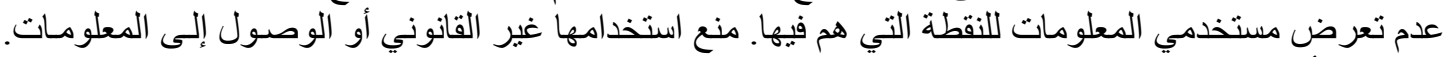

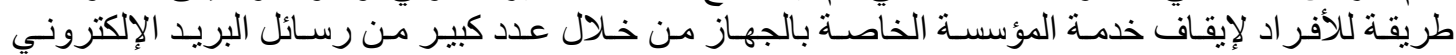
العشو ائية على الثبكة. (قويدر، لإنغ 2018، 268)

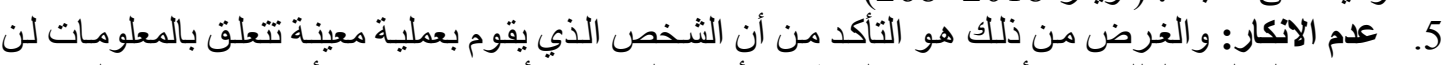

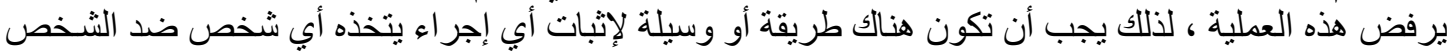

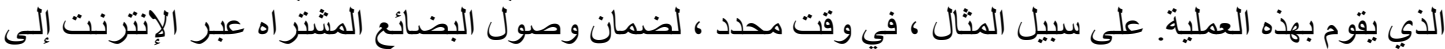

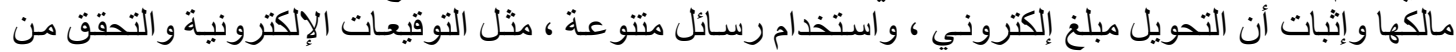

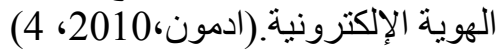




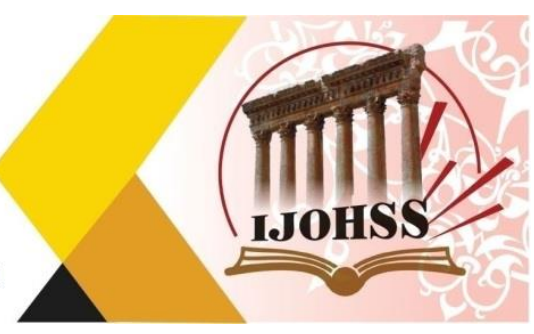

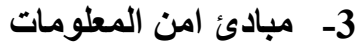

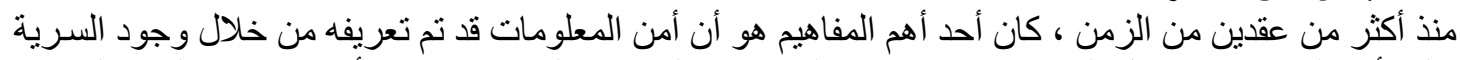

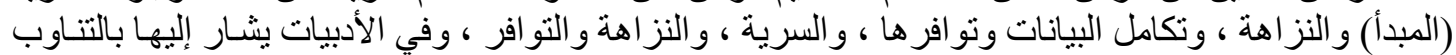

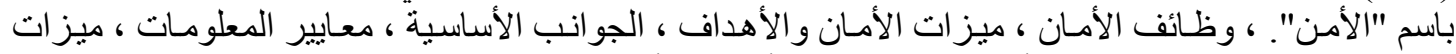

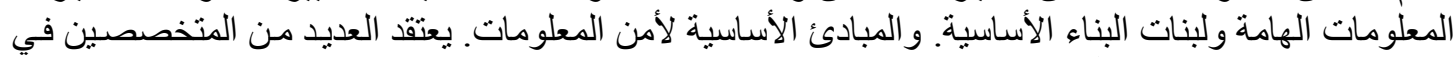

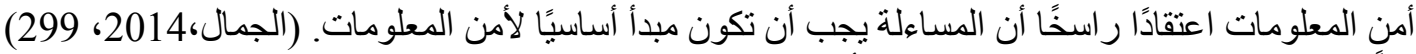

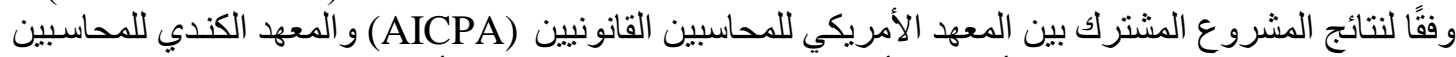

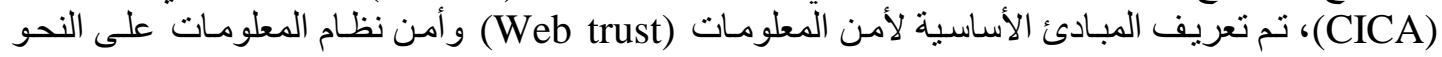

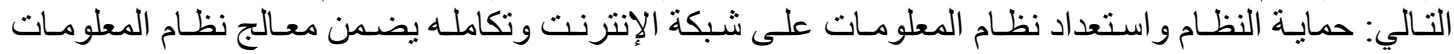
الخصوصية على الويب وسرية نظام المعلومات. (Marshal\&stenbart,2009,17)

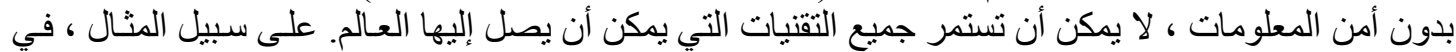

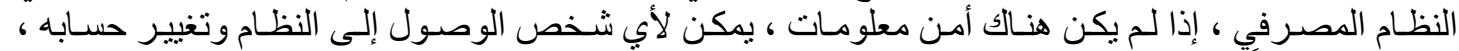
ويصبح مليونير أ بشكل نهائي.

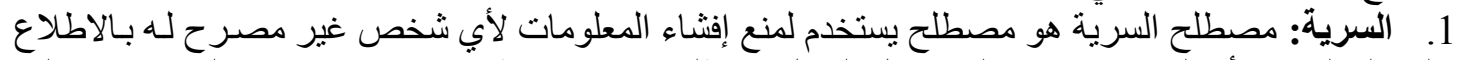

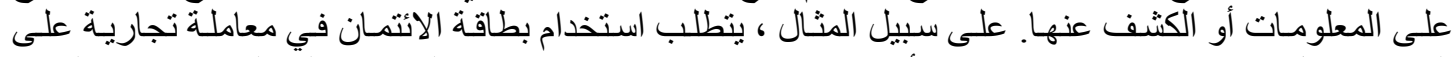

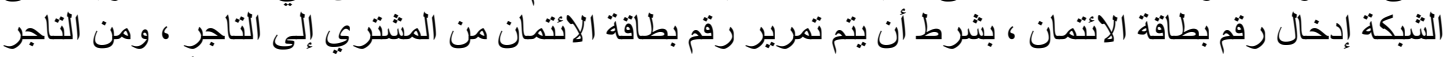

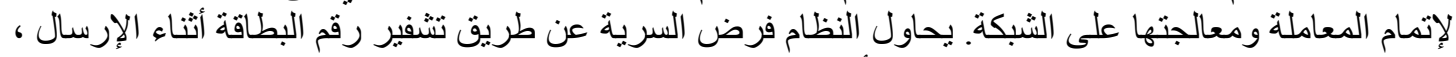

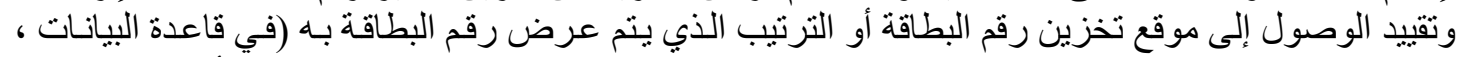

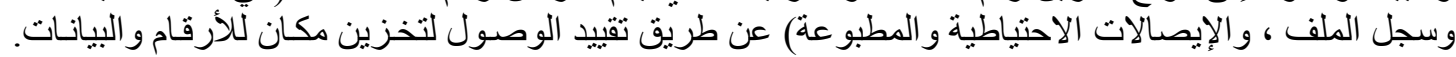

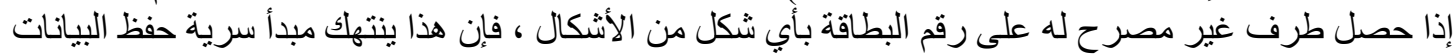

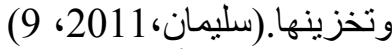

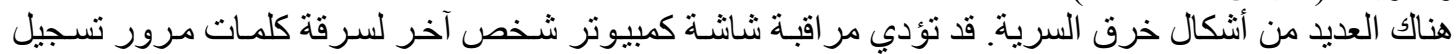

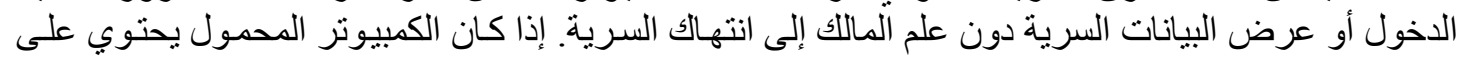

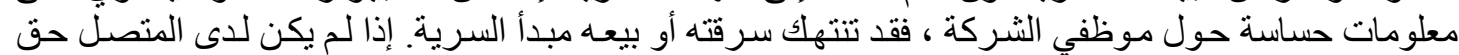

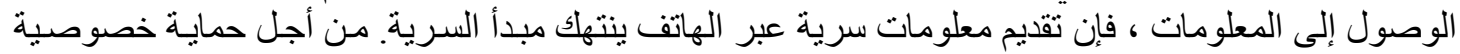

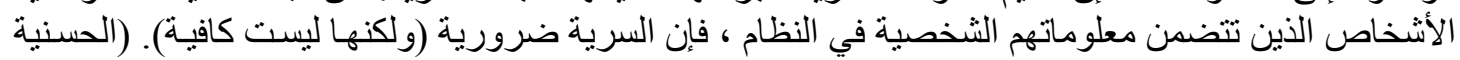

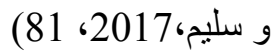

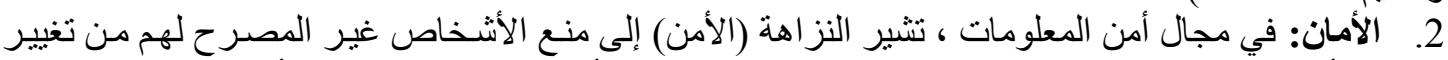

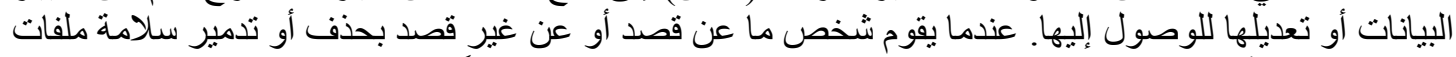

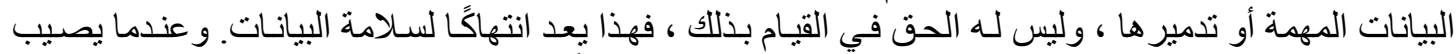

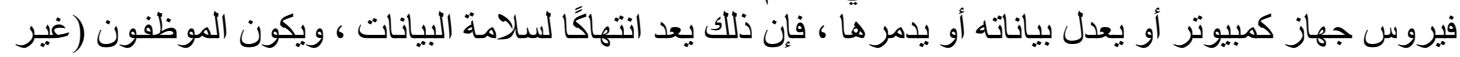

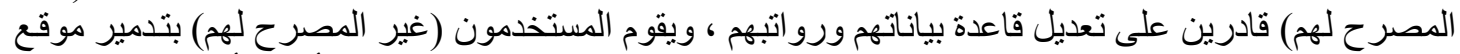

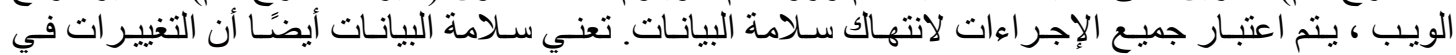

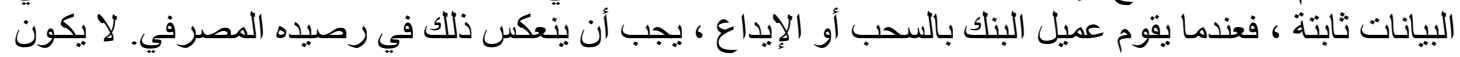

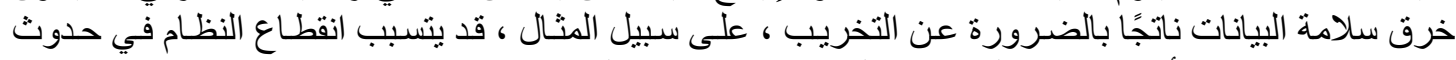

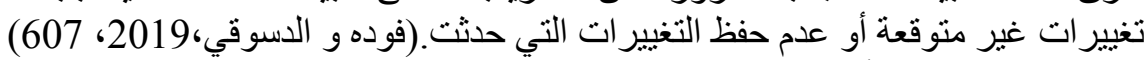

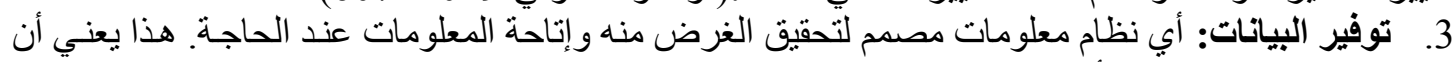

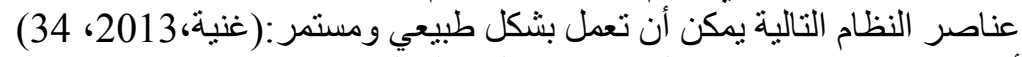

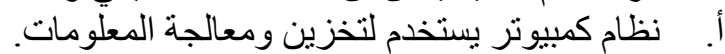

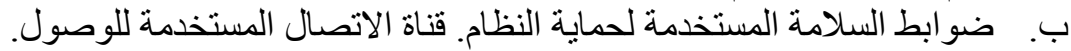

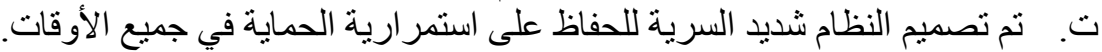

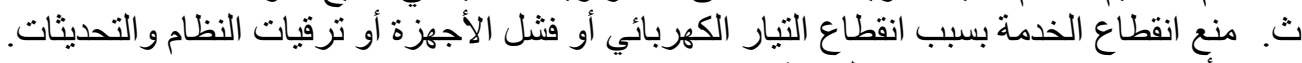

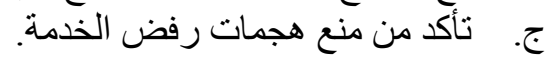




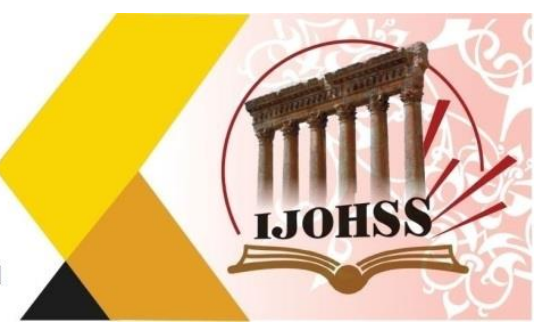

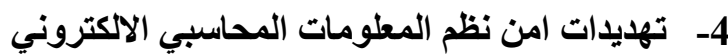

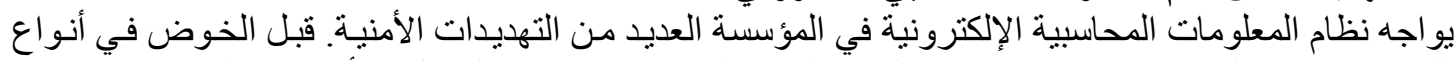

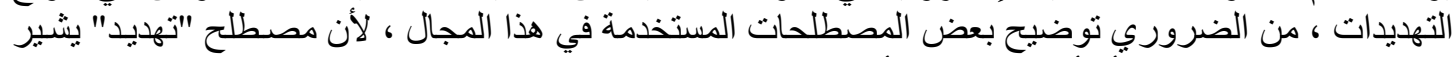

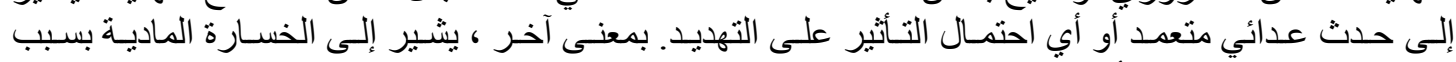

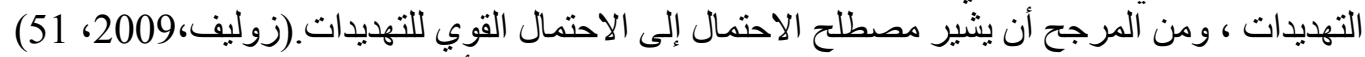

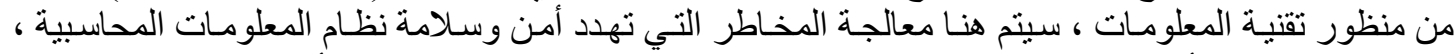

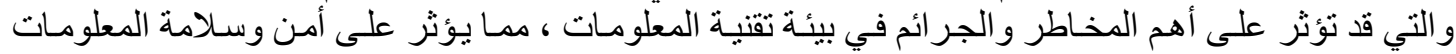

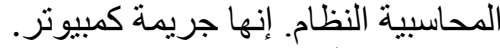

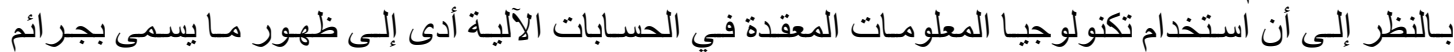

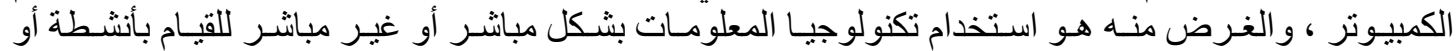

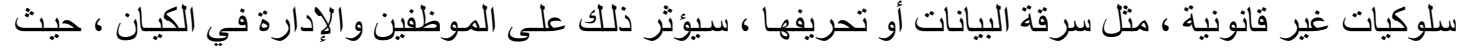

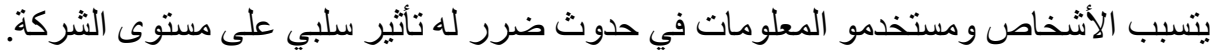

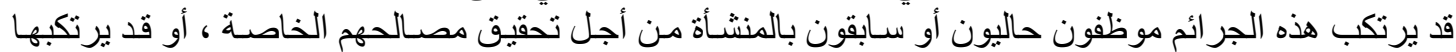

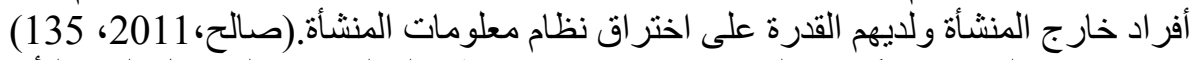

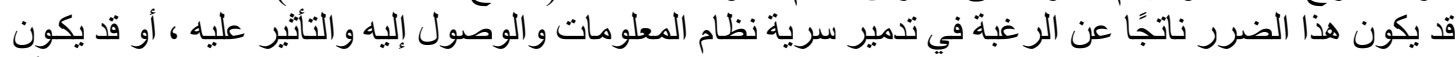

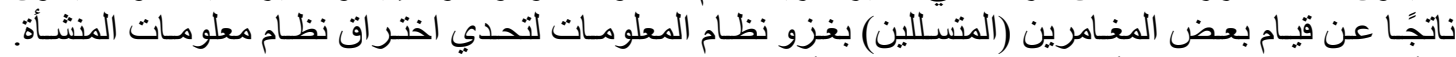

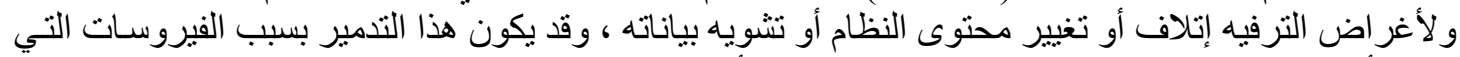

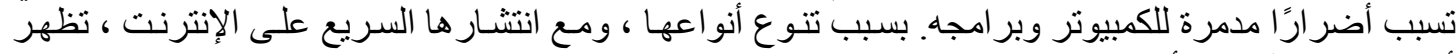

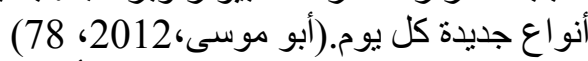

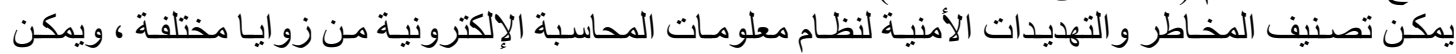

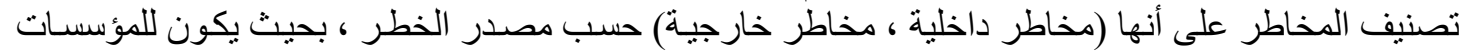

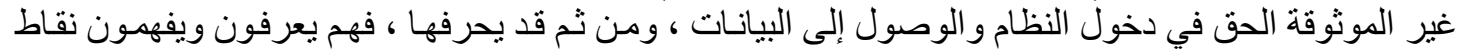

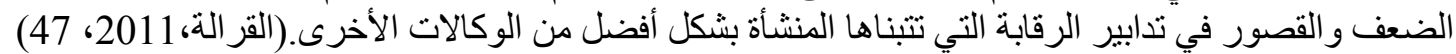

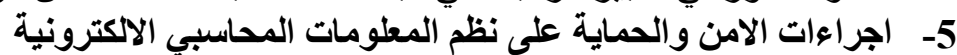

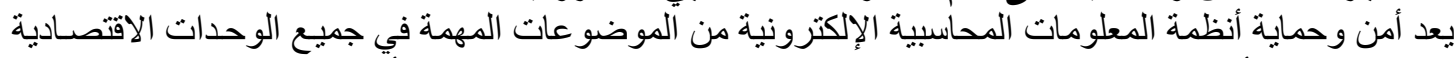

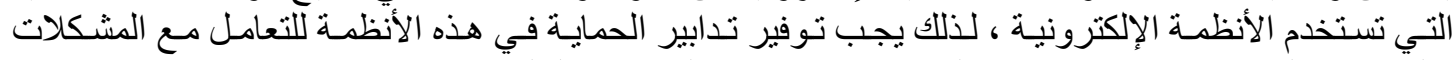

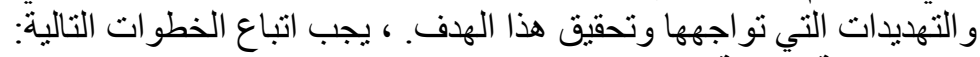

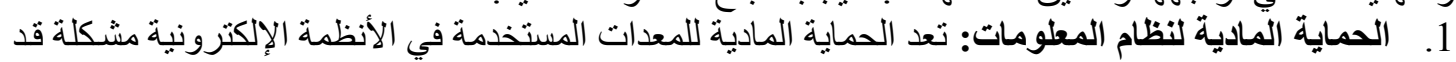

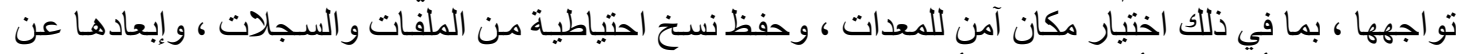

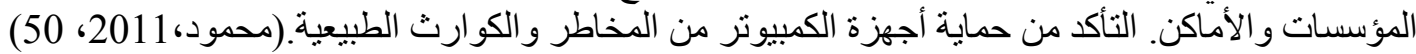

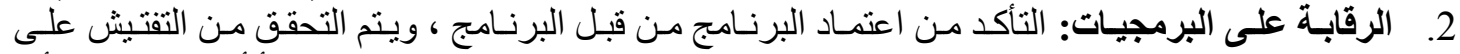

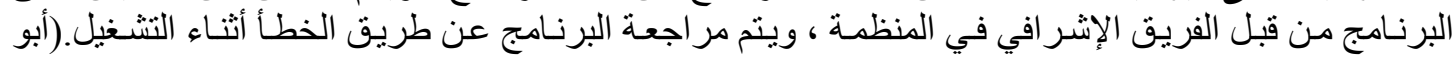

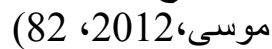

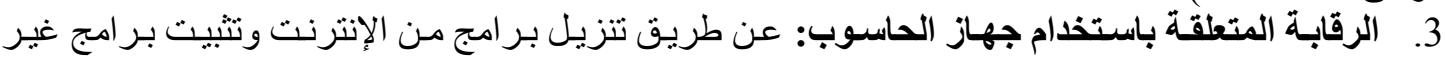

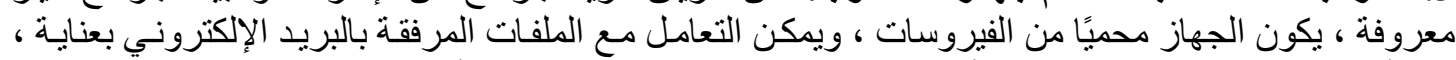

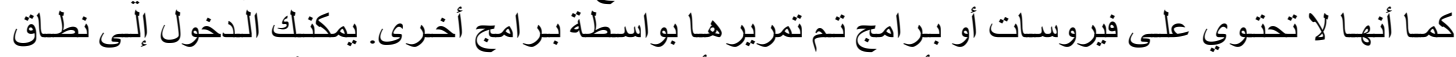

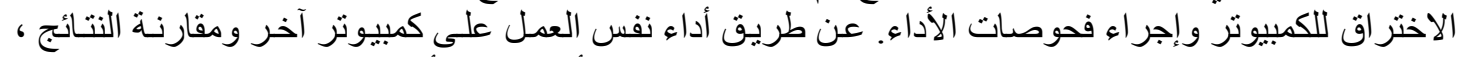

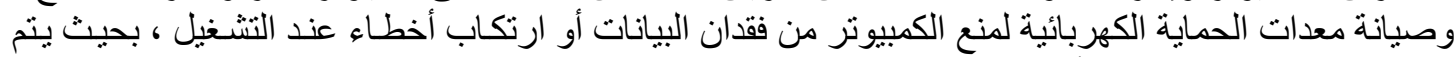
النسخ من الكمبيوتر مقطو عابـا أو متقلبًا.

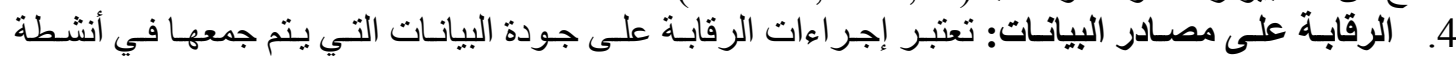

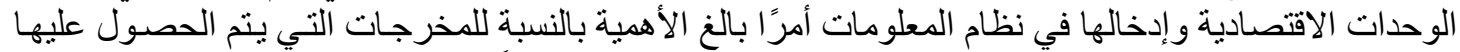

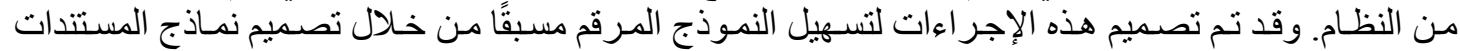

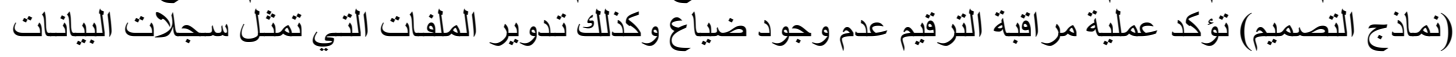




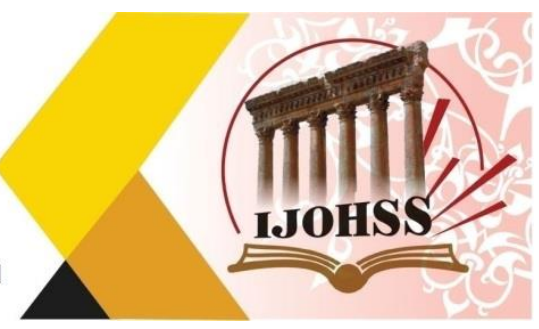

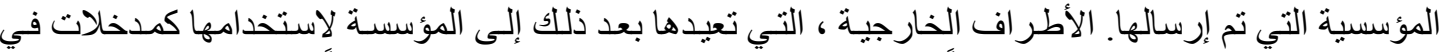

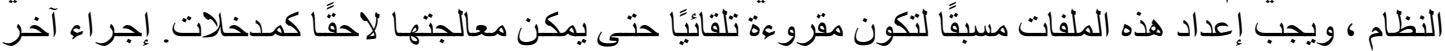

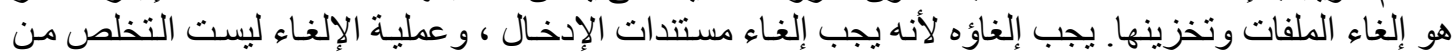

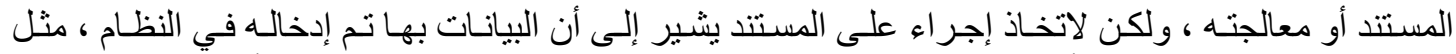

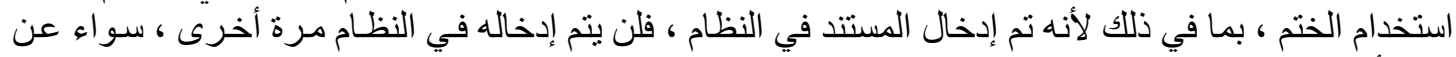

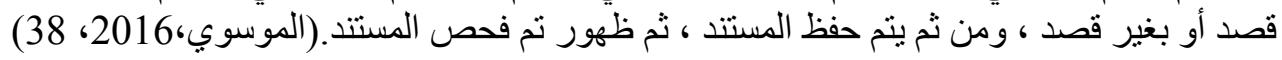

\section{الفصل الثالث: الجاتب العملي للاراسة}

1 وصف مجتمع الاراسة

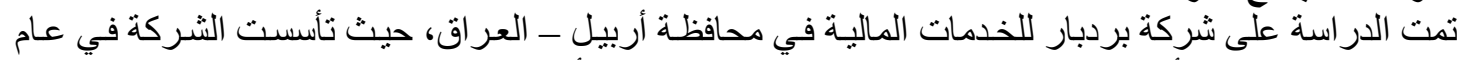

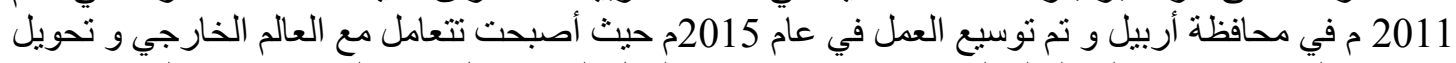

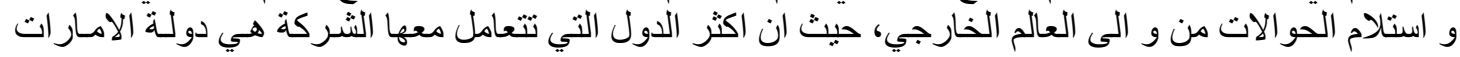

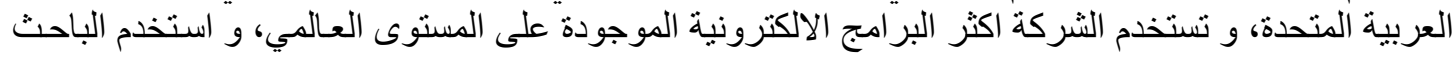

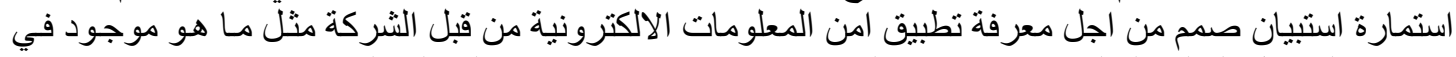

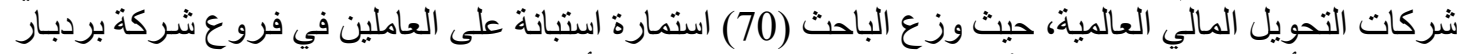

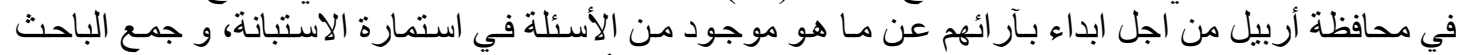

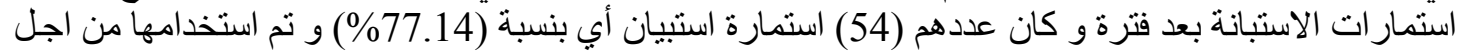

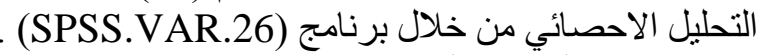
-2 وصف عينة الدراسة:

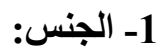
يعرض الجدول (4) التوزيع التكر اري لأفراد عينة الدر اسة حسب الجنس. (4) الجدول

التوزيع التكراري لأفراد عينة الداراسة وفق الجنس

\begin{tabular}{|c|c|c|}
\hline النسبة المئوية & العدد & الجنس \\
\hline$\% 79.6$ & 43 & ذكر \\
\hline$\% 20.4$ & 11 & أنثى \\
\hline$\% 100$ & 54 & المجموع \\
\hline
\end{tabular}

ـ الجدول من إعداد الباحث بواسطة البرنامج

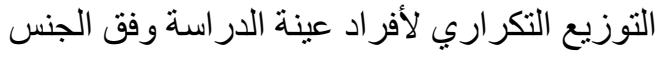

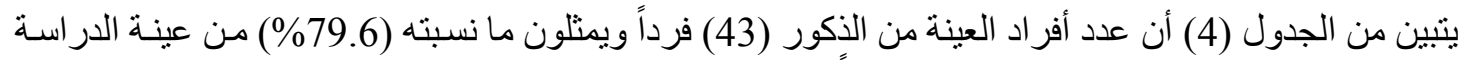

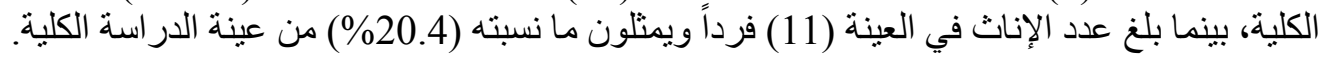

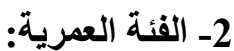

يعرض الجدول (5) التوزيع التكراري لأفراد عينة الدر اسة حسب الفئة العمرية. (5) الجدول

التوزيع التكراري لأفراد عينة الاراسة (5سب الفئة العمرية

\begin{tabular}{|c|c|c|}
\hline النسبة المئوية & العدد & الفئة العمرية \\
\hline$\% 7.4$ & 4 & 30-20 سنة \\
\hline$\% 61.1$ & 33 & 40-31 سنة \\
\hline$\% 31.5$ & 17 & أكبر من 40 سنة \\
\hline$\% 100$ & $\overline{54}$ & المجموع الكلي \\
\hline
\end{tabular}

ـ الجدول من إعداد الباحث بواسطة البرنامج SPSS 


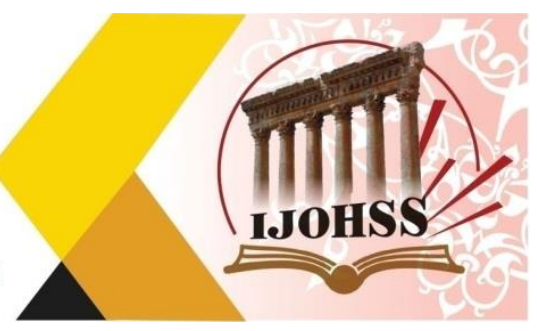

التوزيع التكر اري لأفر اد عينة الدراسة حسب الفئة العمرية

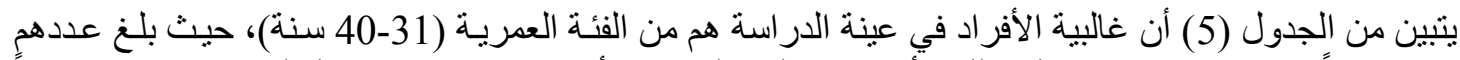

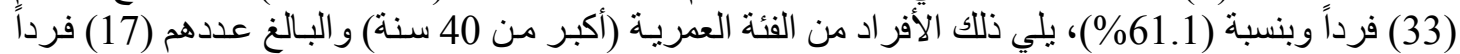

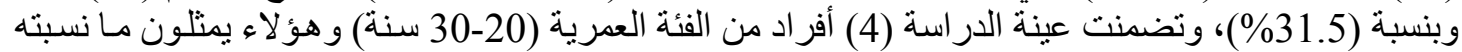

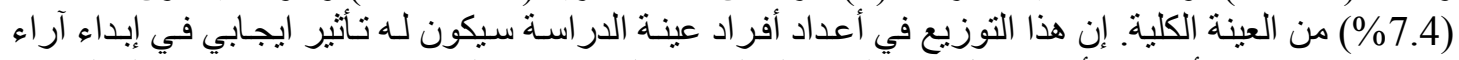

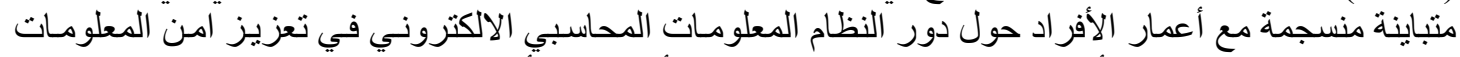

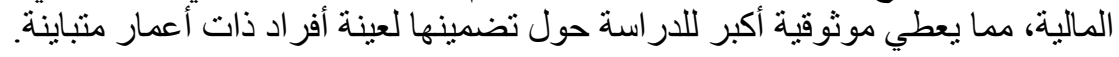

$$
\text { 3- المؤهل العلمي: }
$$

(6) (الجدول

\begin{tabular}{|c|c|c|}
\hline النسبة المئوية & العدد & المؤهل العلمي \\
\hline$\% 3.7$ & 2 & إعدادية فما دون \\
\hline$\% 27.8$ & 15 & معهذ \\
\hline$\% 63.0$ & 34 & بكالوريوس \\
\hline$\% 5.6$ & 3 & ماجستير \\
\hline$\% 100$ & 54 & المجموع \\
\hline
\end{tabular}

التوزيع التكراري لأفراد عينة الارلـة (6) وفق المؤهل العلمي

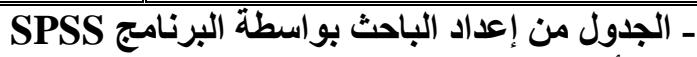

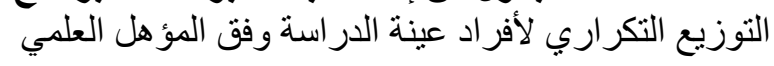

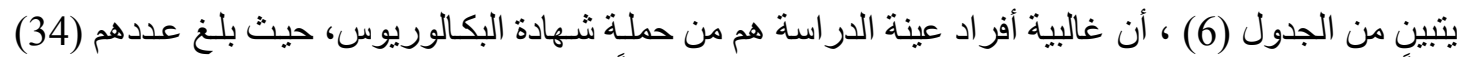

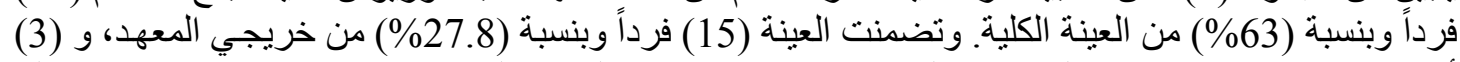

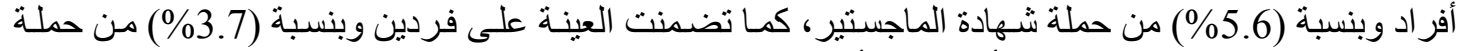

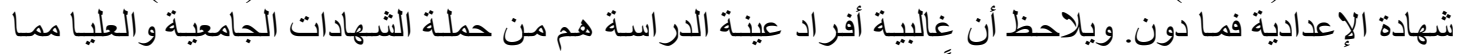

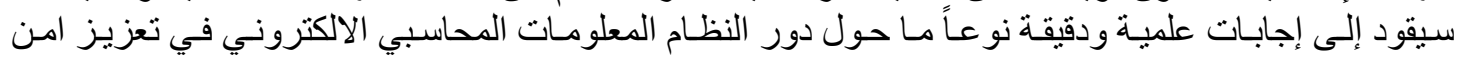

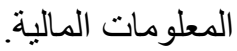

4- - التخصص:

يعرض الجدول (7) التوزيع التكر اري لأفر اد عينة الدر اسة حسب الوظيفة.

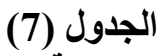

\begin{tabular}{|c|c|c|}
\hline النسبة المئوية & العدد & الوظيفة \\
\hline$\% 31.5$ & 17 & محاسبة \\
\hline$\% 12.6$ & 7 & اقتصـاد \\
\hline$\% 30$ & 16 & إدارة اعمال \\
\hline$\% 3.7$ & 2 & احصاء \\
\hline$\% 18.5$ & 10 & كو مبيوتز \\
\hline$\% 3.7$ & 2 & دون ذلك \\
\hline$\% 100$ & 54 & المجموع \\
\hline
\end{tabular}

التوزيع التكراري لأفراد عينة الاراسة وفق التخصص 
المبلة اللحولية اللملوم الآسانية والإمتصاعية International Journal on Humanities and Social Sciences website:www.ijohss.com Email:editor@ijohss.com العدد (24) سبتمبر 2021 ISSN: $2415-4822$

Volume (24) September 2021

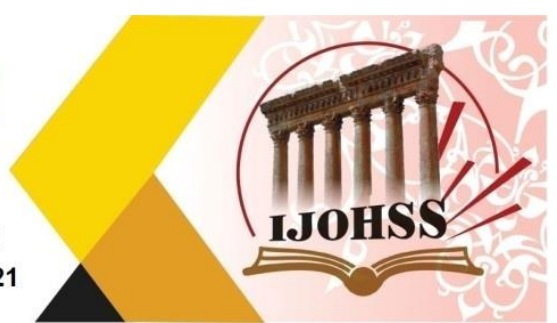

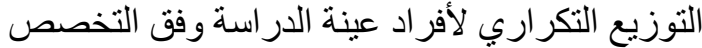
يتبين من الجدول (7) أن غالبية أفر اد عينة الدراسة هم من الموظة الدفين الاكاديميين حيث بلغ عددهم الاجمالي (52)

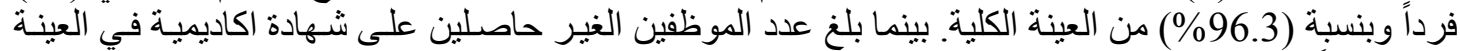
(2) موظفاً وبنسبة (3.7\% (\%) من العبنة العينة الكلية.

3 تبيق أداة الدراسة

بعد توزيع الاستبانات على أفر اد عينة الدر اسة تم ملئها بالإجابات المطلوبة ونم تفريغها كما في الجداول الآتية:

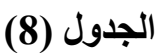

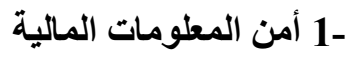

التوزيع التكراري لإجابات أفراد عينة الاراسة على عبارات محور أمن المطلومات المالية

\begin{tabular}{|c|c|c|c|c|c|c|}
\hline لا لاماً تلقـق & 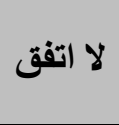 & 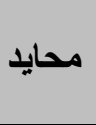 & اتفق & تماماً & 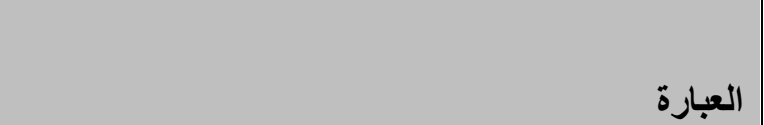 & $ت$ \\
\hline & & & 23 & 31 & لاى شركتكم نظام متكامل لأمن المعلومات. & 1 \\
\hline & & & 2 & 52 & لاى شركتكم نظام التثفير للبيانات و المعلومات. & 2 \\
\hline- & - & - & - & 54 & ضرورة وجود نظام رقابة داخلية لحماية نقل المستندات & 3 \\
\hline- & - & - & 25 & 29 & ضالشركة. وجـود رقابـة لحمايـة التوقيـع الاكترونسي في & 4 \\
\hline- & - & - & 31 & 23 & 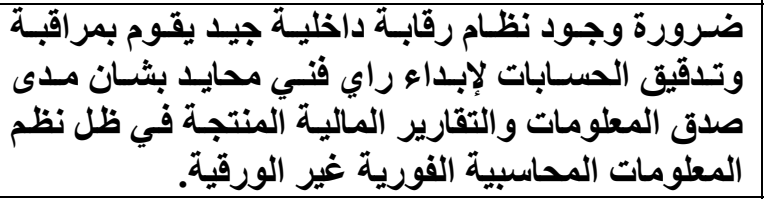 & 5 \\
\hline & & 29 & 25 & - & اشرالك موظفي الشركة في كلمة السر. & 6 \\
\hline- & - & 52 & 2 & - & وجود خلل في الحاسبات المستخدمة عند تطبيق النظام & 7 \\
\hline- & - & 54 & - & - & 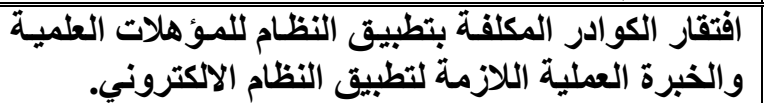 & 8 \\
\hline- & 54 & - & - & - & المستمر. اخضـاع البـرامج الاكترونيـة للتحـــث والتطـوير & 9 \\
\hline- & - & - & 52 & 2 & 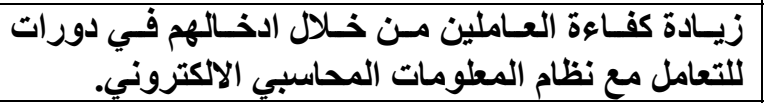 & 10 \\
\hline- & - & - & 31 & 23 & 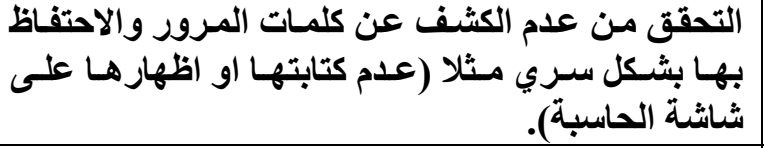 & 11 \\
\hline- & - & - & 52 & 2 & 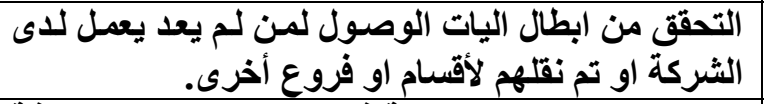 & 12 \\
\hline- & - & - & 25 & 29 & الاحتفاظ بالنسترنخ الاحتياطية في مكان امن خـارج غرفة & 13 \\
\hline- & - & - & - & 54 & 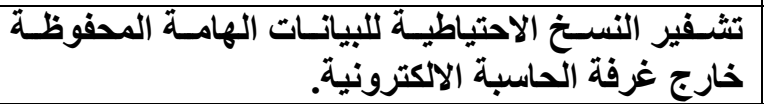 & 14 \\
\hline
\end{tabular}


المجلة اللحولية اللملوم الآسانية والإمتصاعية International Journal on Humanities and Social Sciences website:www.ijohss.com Email:editor@ijohss.com العدد (24) سبتمبر 2021 ISSN: 2415 - 4822

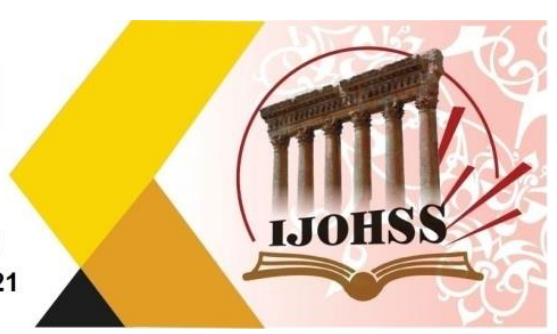

\begin{tabular}{|c|c|c|c|c|c|c|}
\hline تلا اتفــق & لا اتفق & محايا & اتفق & تماماً & العبارة & ت \\
\hline- & - & - & 29 & 25 & 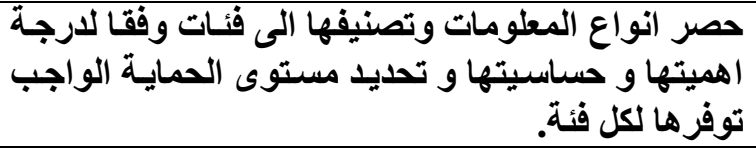 & 15 \\
\hline- & - & - & 31 & 23 & 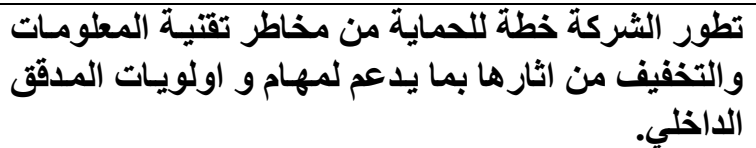 & 16 \\
\hline- & - & - & 52 & 2 & يتم الاشربراف وتوزيع الاختصاصات على العاملين بمركز & 17 \\
\hline- & - & - & 2 & 52 & 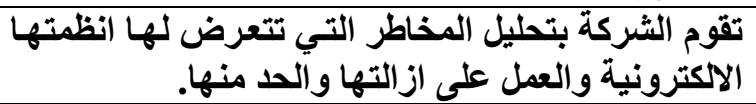 & 18 \\
\hline- & - & - & 29 & 25 & والامن المرتبط بها للمبرمجين وات تلديبة على نظلين تقنية المعلومات المستخين & 19 \\
\hline- & - & - & 30 & 24 & 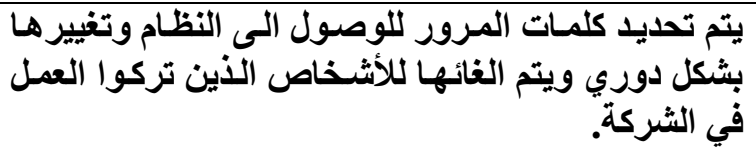 & 20 \\
\hline
\end{tabular}

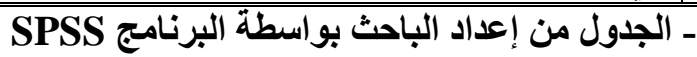

(9) الجدول (9) (9)

$$
\text { 2- }
$$

التوزيع التكراري لاجابات أفراد عينة الدراسة على عبارات محور الرقابة على أمن المعلومات المالية

\begin{tabular}{|c|c|c|c|c|c|c|}
\hline تلاماً اتفـق & لا لا اتفق & 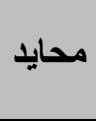 & اتفق & تماماً & العبارة & ت \\
\hline- & - & - & 2 & 52 & توجاسـ رقابـة امنيـة على عمليـة الوصـول الى برمجيـات & 1 \\
\hline & 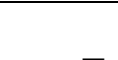 & - & 53 & 1 & توجد رقابة امنية على البيانات؟ & 2 \\
\hline & & 23 & 30 & 1 & توجد رقابة امنية على المخرجات؟ & 3 \\
\hline & & & 24 & 30 & توجد رقابة امنية على مستخدمي البرامج؟ & 4 \\
\hline & & & & 54 & توجد رقابة امنية على فصل المهام والواجبات؟ & 5 \\
\hline- & - & 23 & 30 & 1 & تلوجد رقابة امنية متعلقة بالتجاوزات للوصول الطبيعي & 6 \\
\hline- & - & 1 & 24 & 29 & توجادية رقابـة امنية على عمليـة الوصول الى المكونـات & 7 \\
\hline- & - & 1 & 24 & 29 & 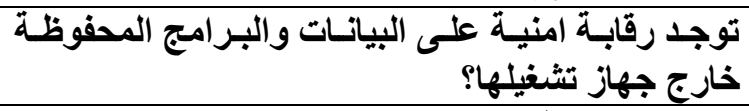 & 8 \\
\hline- & - & - & 52 & 2 & 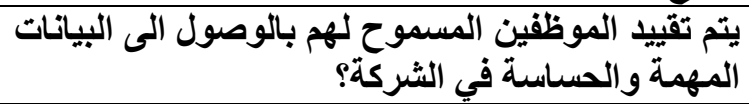 & 9 \\
\hline & & & 1 & 53 & تتضـــمن سياسـيات التوظيـف الاطـلاع علــى خلفيــات & 10 \\
\hline
\end{tabular}




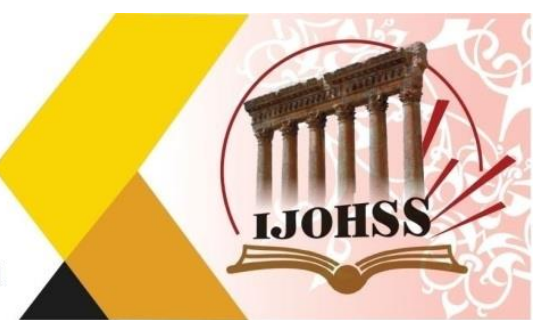

\begin{tabular}{|c|c|c|c|c|c|c|}
\hline & & & & & الموظفين لتقليل احتمالية توظيف افراد غير امينين؟ & \\
\hline- & - & - & 29 & 25 & بشكل جيا؟ك توثيق يظهر ان المستخدمين للأنظمة تم تدريبهم & 11 \\
\hline- & 1 & 47 & 6 & - & 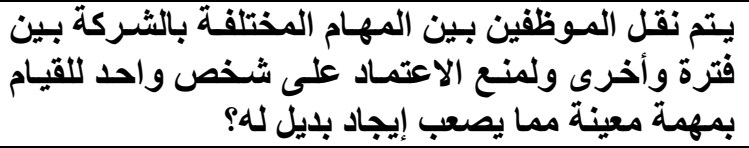 & 12 \\
\hline- & 21 & 29 & 2 & - & 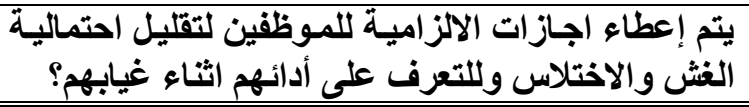 & 13 \\
\hline
\end{tabular}

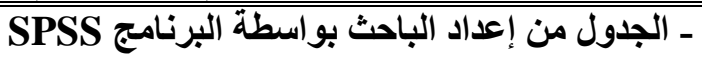

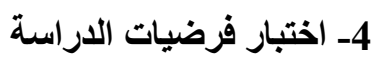

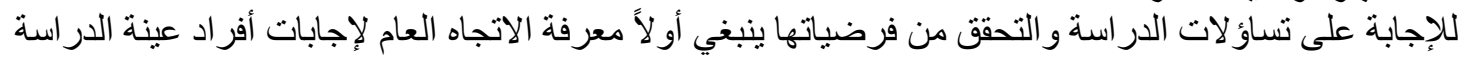

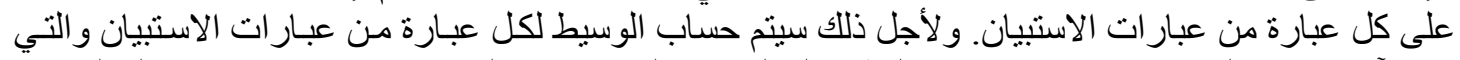

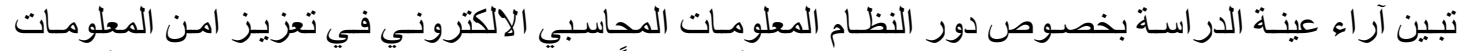

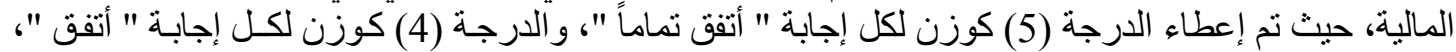

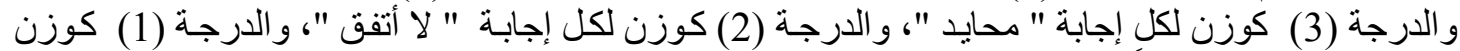

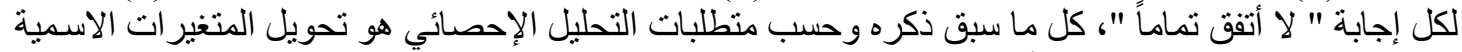

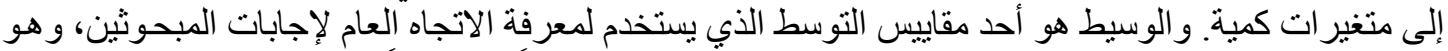

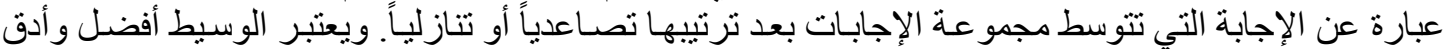

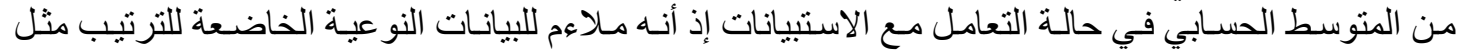

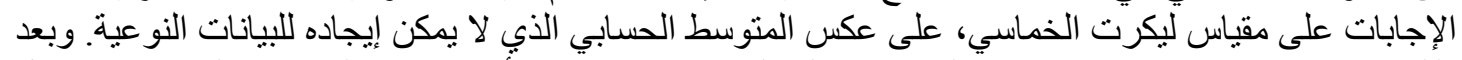

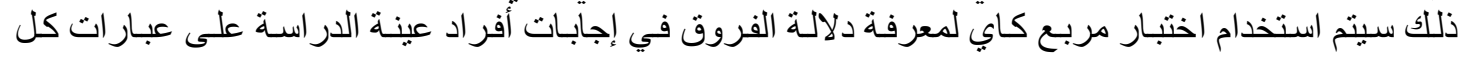

تتص فرضية الدراسة الرئيسية على: " يساعد نظام المعلومات المحاسبية الإكترونية في تعزيز الأمن والرقابة

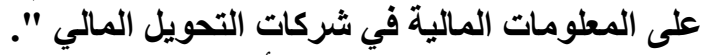
وتتفرع منها فرضيتين فرعيتين وأن اختبار هما بعني اختبار الميلي الفرضية الرئيسية، و على النحو الآتي:

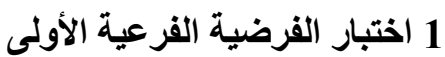
تتص الفرضية الفر عية الأولى على الألى أن: " السياسات والإجراءات المستخدمة في شركات التحويل المـالي آمنـة

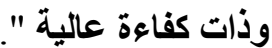

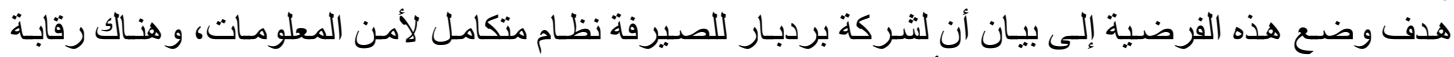

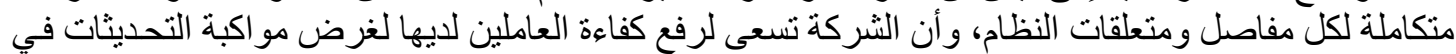

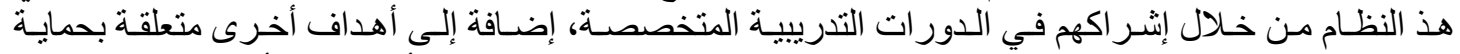

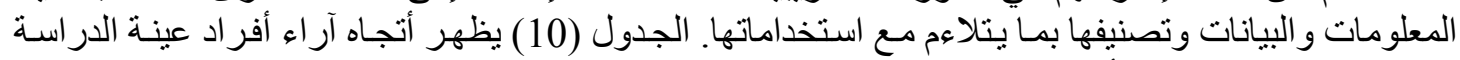
بخصوص عبار ات محور أمن المعلومات المالية

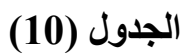

الوسيط لإجابات أفراد عينة الاراسة على عبارات محور أمن المعلومات المالية

\begin{tabular}{|c|c|c|c|}
\hline & الوسيط & \multirow[b]{2}{*}{ 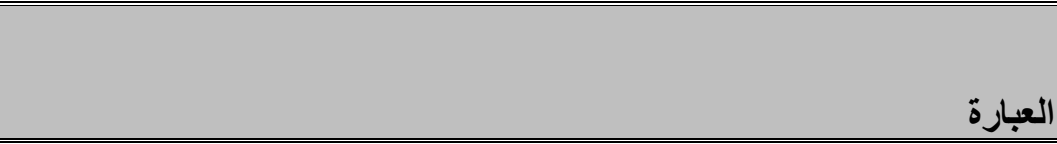 } & \multirow[b]{2}{*}{ ت } \\
\hline الإجابة & 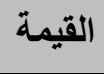 & & \\
\hline أتقق تماماً & 5 & لدى شركتكم نظام متكامل لأمن المعلومات. & 1 \\
\hline أتفق تماماً & 5 & لدى شركتكم نظام التشفير للبيانات والمعلومات. & 2 \\
\hline أتفق & 4 & ضرورة وجود نظام رقابة داخلية لحماية نقل المستندات الاكترونية في الثركة. & 3 \\
\hline
\end{tabular}


المجلة اللحولية اللملوم الآسانية والإمتصاعية International Journal on Humanities and Social Sciences website:www.ijohss.com Email:editor@ijohss.com العدد (24) سبتمبر 2021 ISSN: 2415 - 4822

Volume (24) September 2021

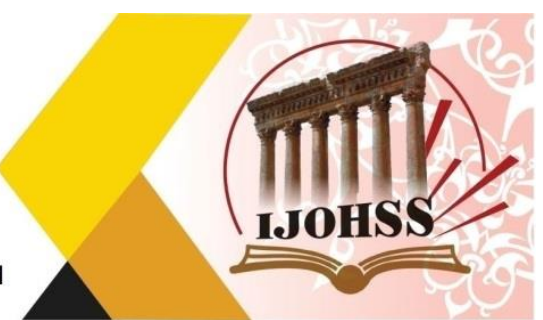

\begin{tabular}{|c|c|c|c|}
\hline أتفق تمـامًاً & 5 & ضرورة وجود رقابة لحماية التوقيع الاكتروني في الثركة. & 4 \\
\hline أتفق & 4 & 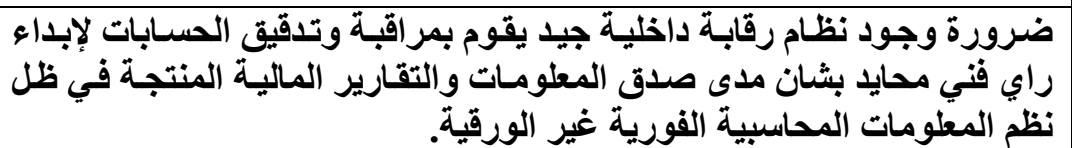 & 5 \\
\hline محايد & 3 & اشراك موظفي الثركة في كلمة السر. & 6 \\
\hline محايد & 3 & وجود خلل في الحاسبات المستخدمة عند تطبيق النظام المستخدم. & 7 \\
\hline محايد & 3 & 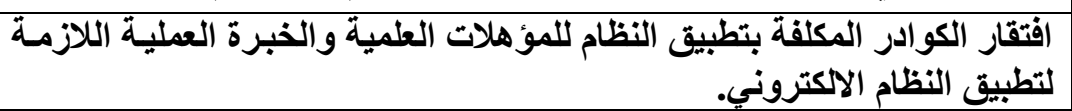 & 8 \\
\hline لا لأتقق & 2 & عدم اخضاع البرامج الاكتترونية للتحديث والتطوير المستمر. ع & 9 \\
\hline أتثق & 4 & زالمحاسبي كفاعة العكترونين من خلال ادخالهم في دورات للتعامل مـع نظـام المعلومـات & 10 \\
\hline أتثق & 4 & كتابتها او اظهارم الكا على شنف عن كلمات الحاسبة). & 11 \\
\hline أتثق & 4 & 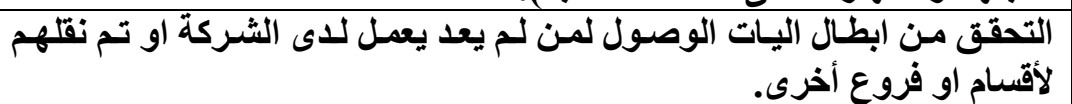 & 12 \\
\hline أتفق تمـامًاً & 5 & الاحتفاظ بالنسخ الاحتياطية في مكان امن خارج غرفة الحاسبة الاككترونية. & 13 \\
\hline أتثق تماماً & 5 & 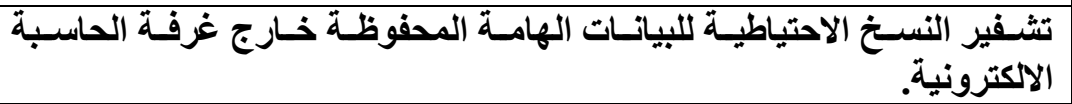 & 14 \\
\hline أتثقى & 4 & 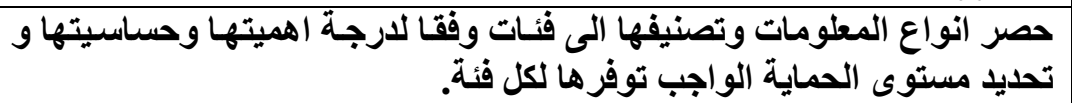 & 15 \\
\hline أتفق & 4 & 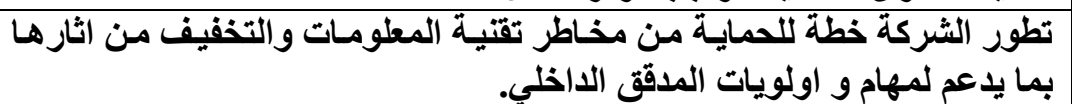 & 16 \\
\hline أتفق & 4 & يتم الاشراف وتوزيع الاختصاصات على الَعاملين بمركز الحاسوب. & 17 \\
\hline أتثق تماماً & 5 & تقوم الثركة بتحليل المخاطر التي تتعرض لها انظمتها الاكترونيـة والعمل على & 18 \\
\hline أتفق & 4 & للمبروجين وجوالمشفلين المستخذمين تلى نظم تقنية المعلومـات والامن المرتبط بها & 19 \\
\hline أتفق & 4 & 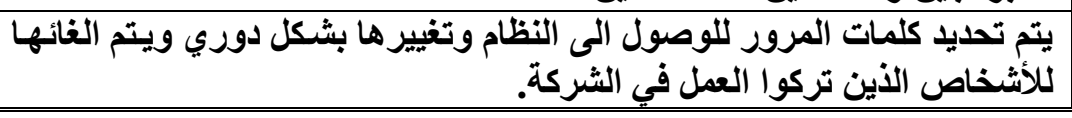 & 20 \\
\hline أتقق & 4 & ي عبارات المحور & \\
\hline
\end{tabular}

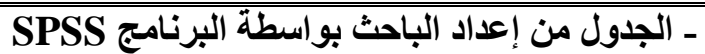

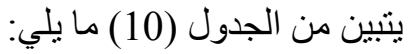

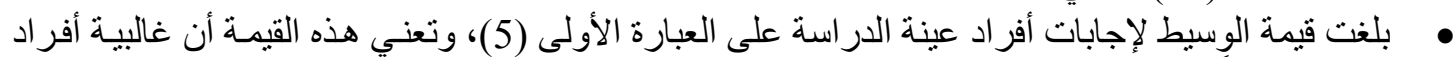

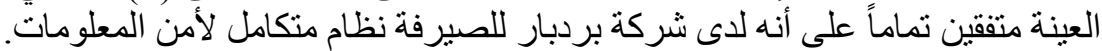

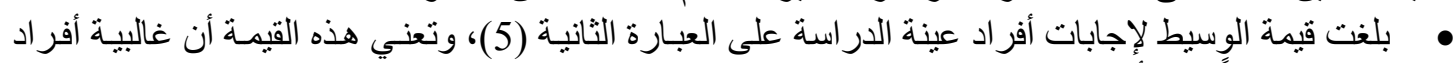

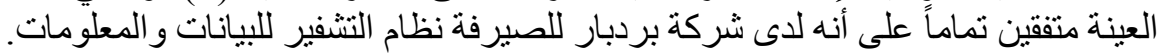

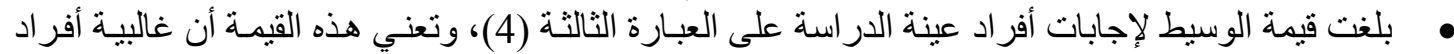

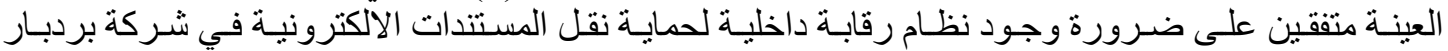
ل الصيرفة. 


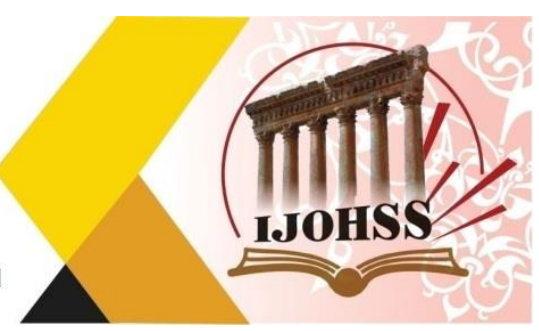

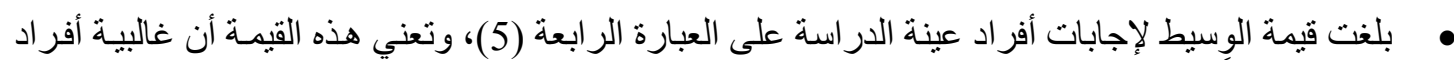

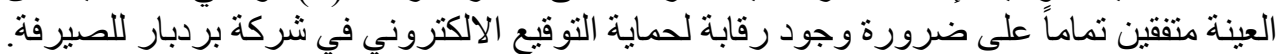

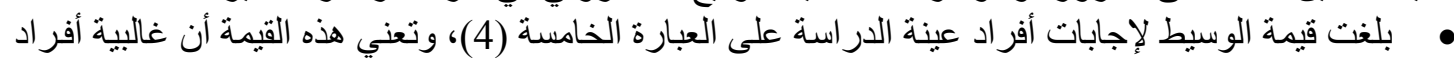

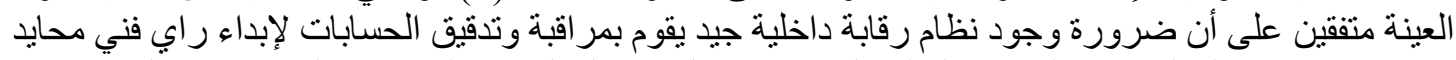

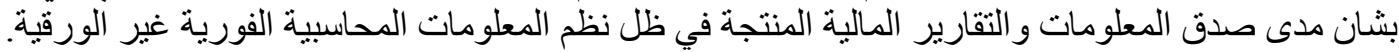

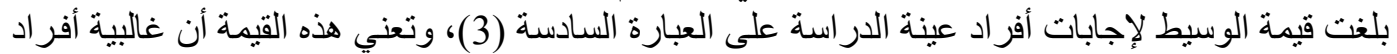

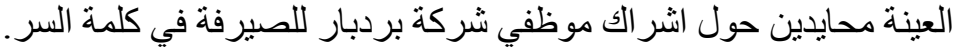

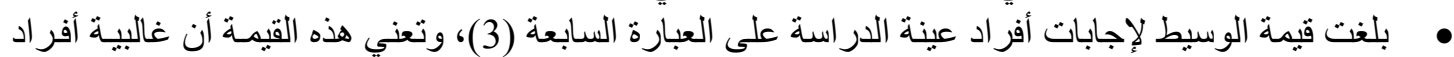

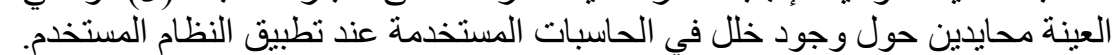

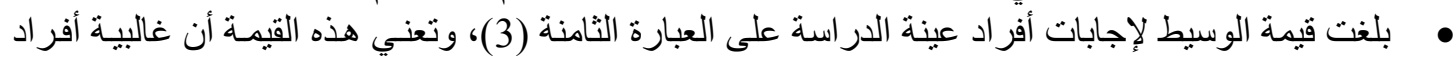

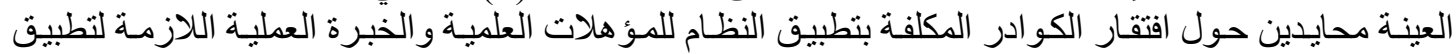

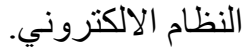

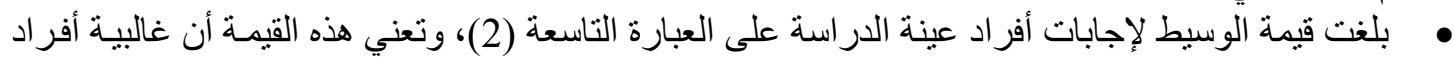

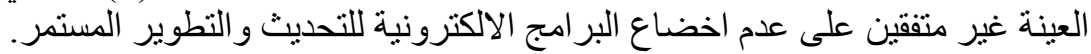

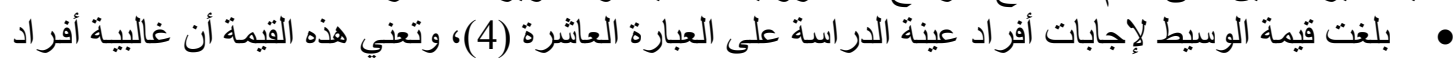

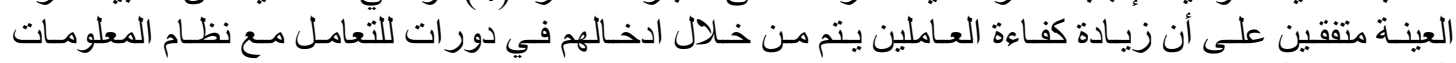
المحاسبي الالكتروني. • بلغت قيمة الوسيط لإجابات أفر اد عينة الدر اسة على العبارة الحادية عشر (4)، وتعني هذه القيمـة أن غالبيـة

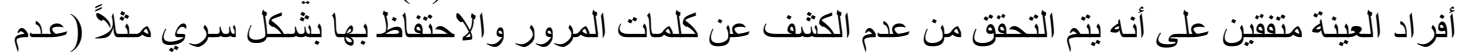
كتابتها او اظهار ها على شانشة الحاسبة).

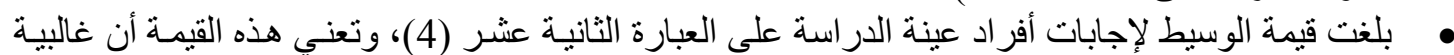

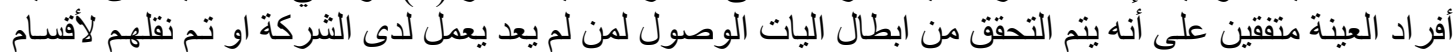

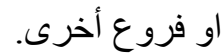

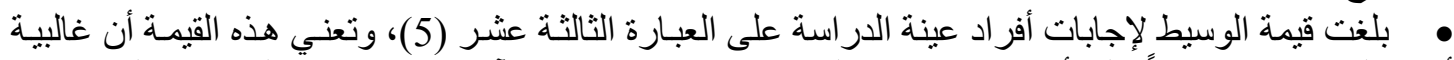

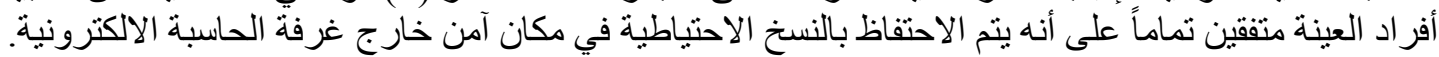

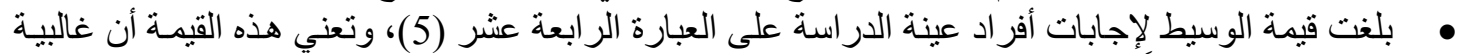

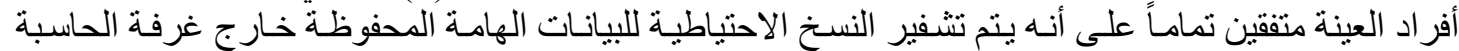
الالكترونية. • بلغت قيمة الوسيط لإجابات أفر اد عبنة الدر اسة على العبارة الخامسة عشر (4)، وتعني هذه القيمة أن غالبية

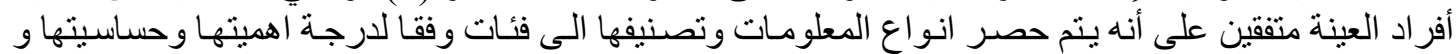

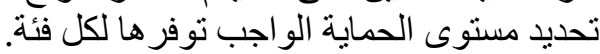

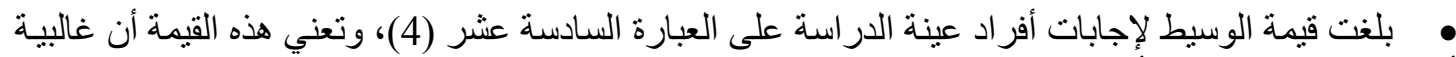

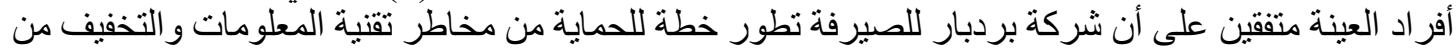

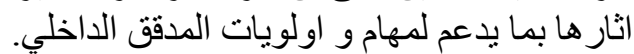

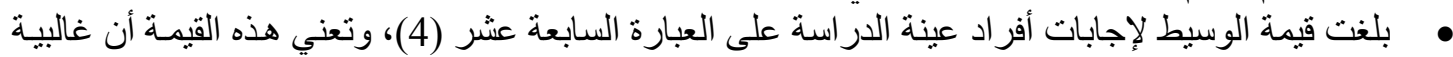

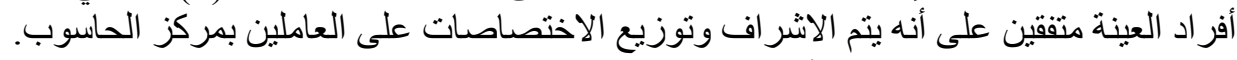

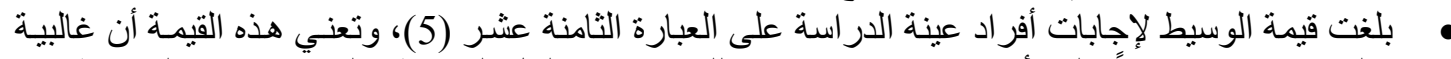

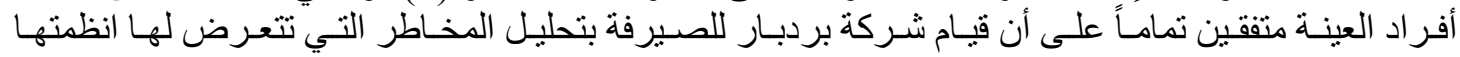

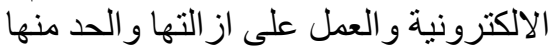

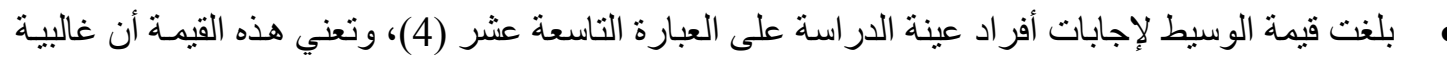

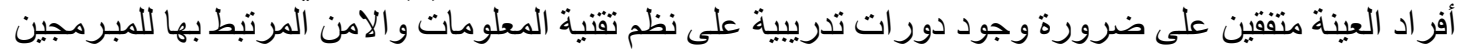




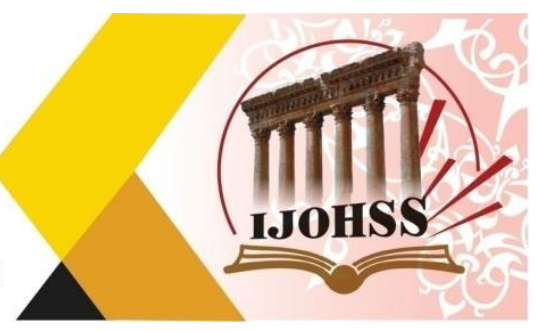

• بلغت قيمة الوسيط لإجابـات أفر اد عينـة الدر اسـة على العبارة العشرون (4)، وتعني هذه القيمـة أن غالبيـة

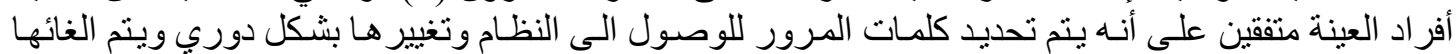

للأشخاص الذين تركوا العمل في الثركة.

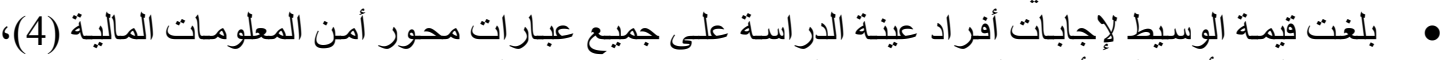
وتعني هذه القيمة أن غالبية أفراد العينة متفقين على ما جاء بعبار ات هذا العيد المحور.

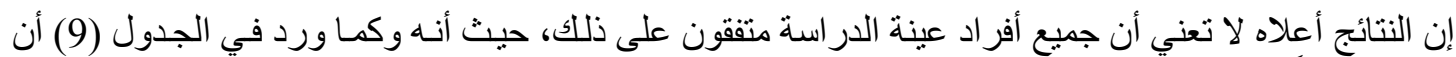

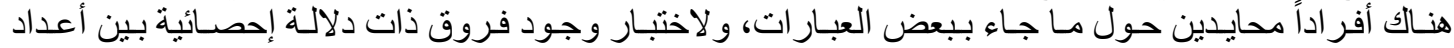

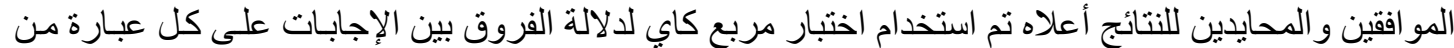
عبار ات محور أمن المعلومات المالية، الجدول رقم (10) يلخص نتائج الاختبار لهذه العبارات:

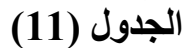

نتائج اختبار مربع كاي للفروق للإجابات على عبارات محور أمن المعلومات المالية

\begin{tabular}{|c|c|c|c|}
\hline Sig. & قيمـة مربـع كايع & 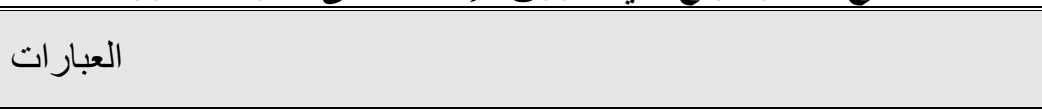 & $ت$ \\
\hline 0.276 & 1.185 & لدى شركتكم نظام متكامل لأمن المعلومات. & 1 \\
\hline 0.000 & $46.296 * *$ & لاى شركتكم نظام التشفير للبيانات والمعلومات. & 2 \\
\hline - & - & ضـرورة وجـود نظـام رقابـة داخليـة لحمايـة نقل المسـتندات الاككترونيـة فـي & 3 \\
\hline 0.586 & 0.296 & ضرورة وجود رقابة لحماية التوقيع الاكتروني في الثركة. & 4 \\
\hline 0.276 & 1.185 & 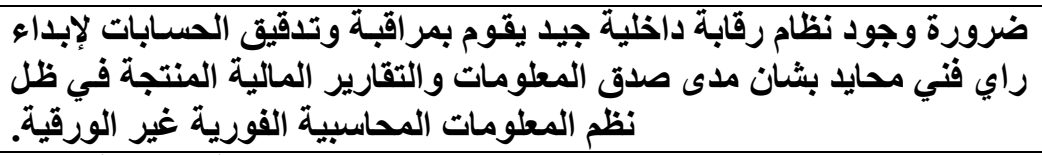 & 5 \\
\hline 0.586 & 0.296 & ا اشرالك موظفي الشركة في كلمة السر. & 6 \\
\hline 0.000 & $46.296 * *$ & وجود خلل في الحاسبات المستخدمة عند تطبيق النظام المستخدم. & 7 \\
\hline- & - & 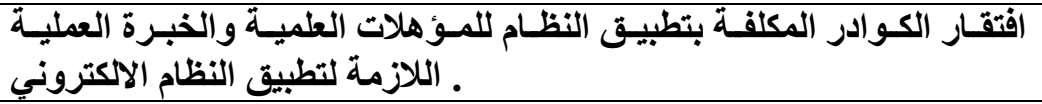 & 8 \\
\hline - & - & عدم اخضاع البرامج الاكترونية للتحديث والتطوير المستمر. & 9 \\
\hline 0.000 & $46.296 * *$ & زيادة كفاءة العاملين من خلال الخالهم في دورات للتعامل مع نظام المعلومسات & 10 \\
\hline 0.276 & 1.185 & 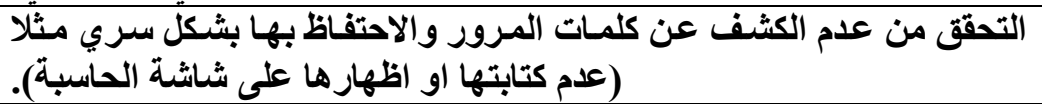 & 11 \\
\hline 0.000 & $46.296 * *$ & 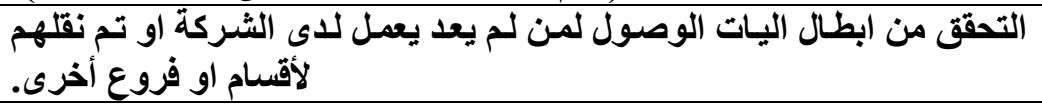 & 12 \\
\hline 0.586 & 0.296 & الاحتفاظ بالنسخ الاحتياطية في مكان امن خارج غرفة الحاسبة الاكترونية. & 13 \\
\hline- & - & تثـفير النسـخ الاحتياطية للبياتـات الهامـة المحفوظـة خـارج غرفـة الحاسبـة & 14 \\
\hline 0.586 & 0.296 & 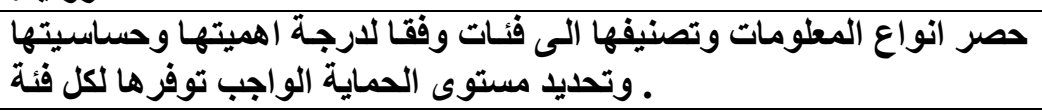 & 15 \\
\hline 0.276 & 1.185 & تطور الثركة خطة للحماية من مخاطر تقتية المعلومات والتخفيف من اثارهـا & 16 \\
\hline
\end{tabular}


المجلة اللحولية اللملوم الآسانية والإمتصاعية International Journal on Humanities and Social Sciences website:www.ijohss.com Email:editor@ijohss.com ISSN: 2415 - 4822

العدد (24) سبتمبر 2021 Volume (24) September 2021

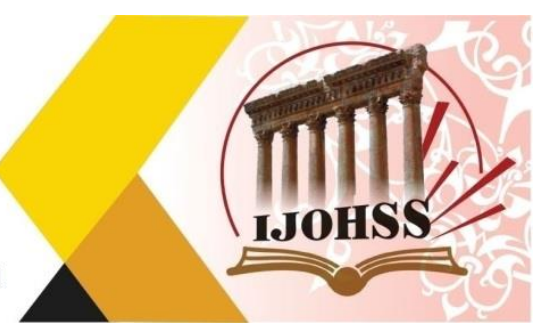

\begin{tabular}{|c|c|c|c|}
\hline & & بما يدعم لمهام و اولويات المدقق الداخلي. & \\
\hline $\mathbf{0 . 0 0 0}$ & $46.296 * *$ & يتم الاشراف وتوزيع الاختصاصات على العاملين بمركز الحاسوب. & 17 \\
\hline $\mathbf{0 . 0 0 0}$ & $46.296 * *$ & 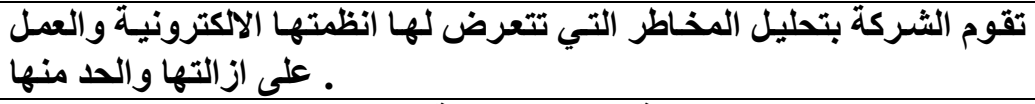 & 18 \\
\hline 0.586 & 0.296 & 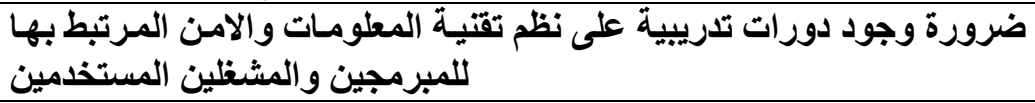 & 19 \\
\hline 0.586 & 0.296 & 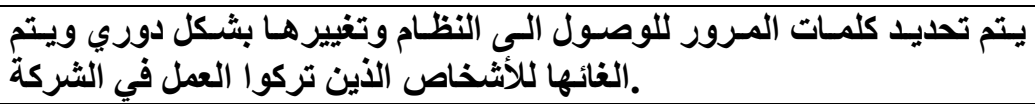 & 20 \\
\hline
\end{tabular}

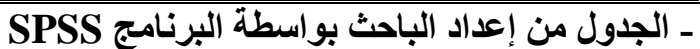

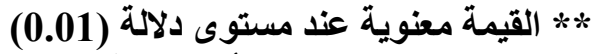
ويمكن تفسير نتائج الجدول أعلاه كالآتي:

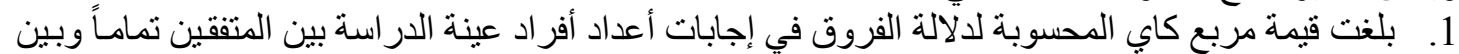

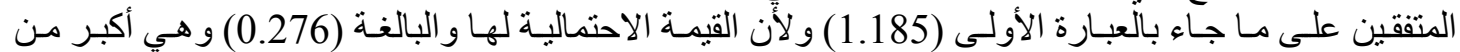

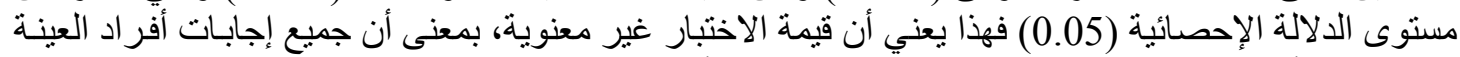

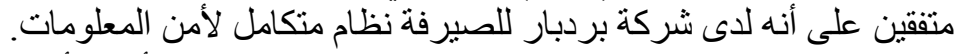

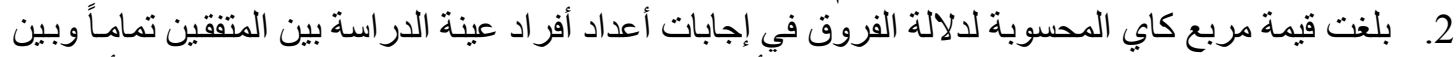

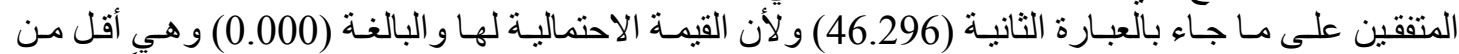

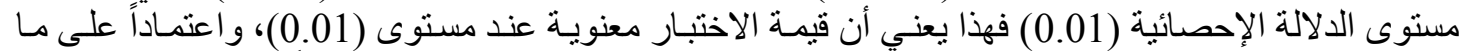

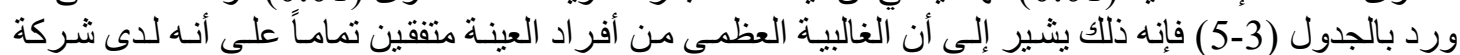

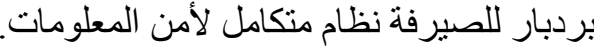

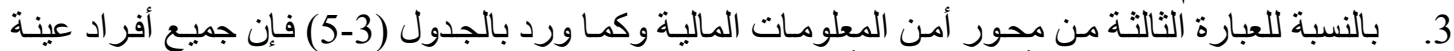

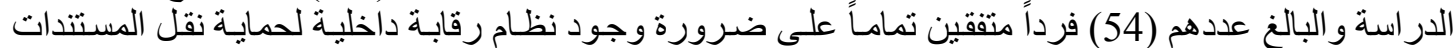

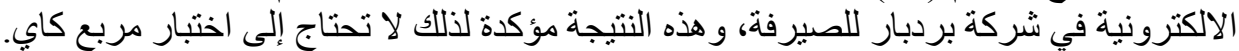

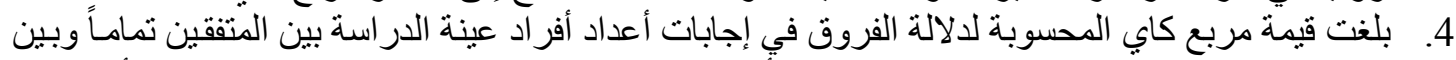

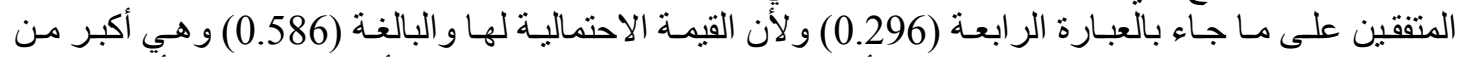

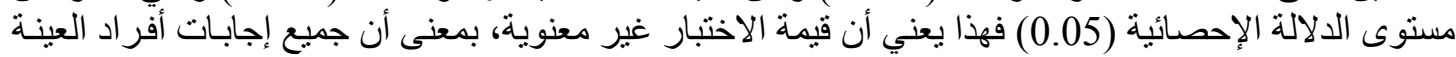

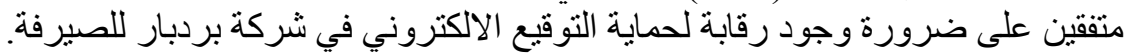

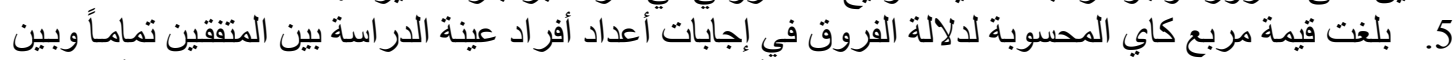

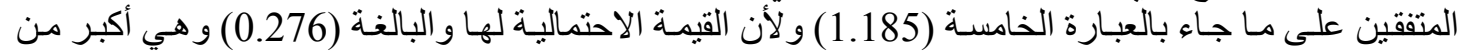

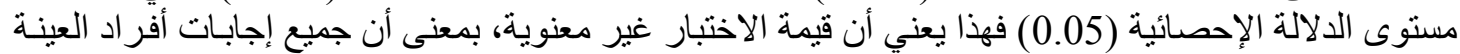

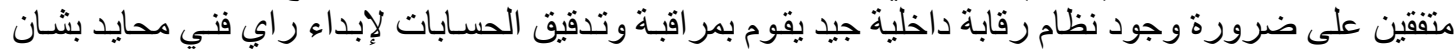

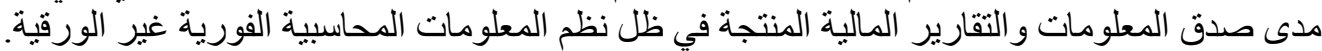

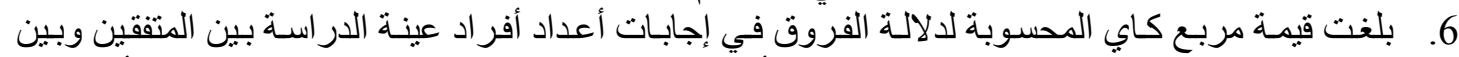

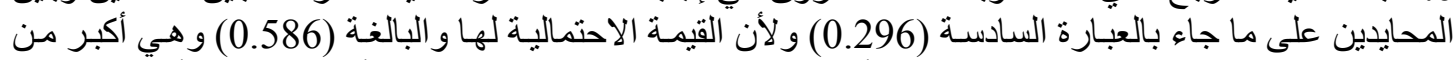

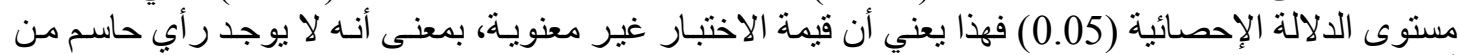

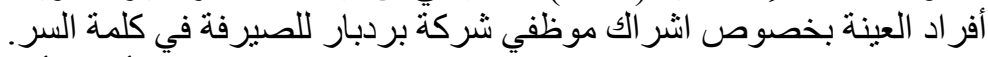

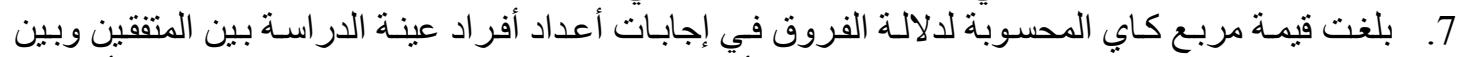

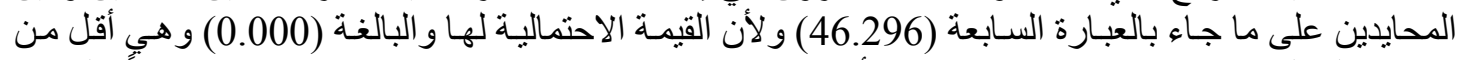

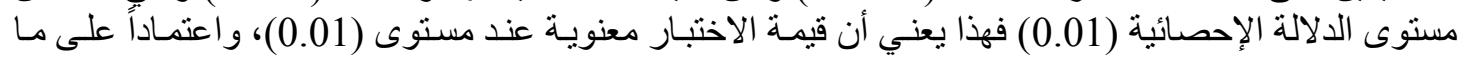

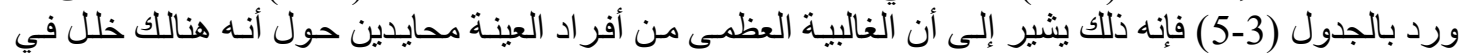
الحاسبات المستخدمة عند تطبيق النظام المستخدم. 


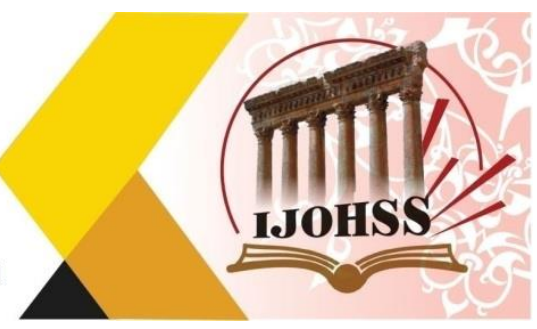

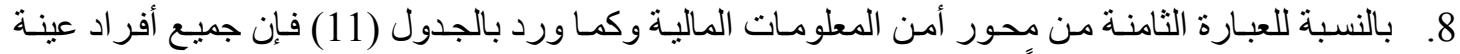

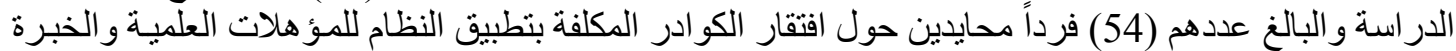

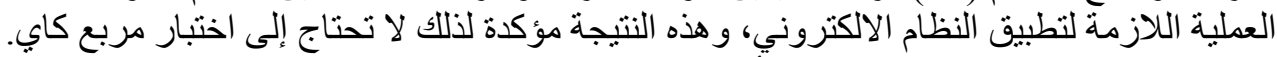

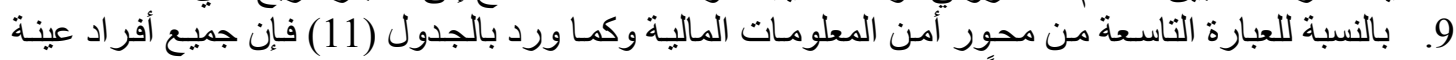

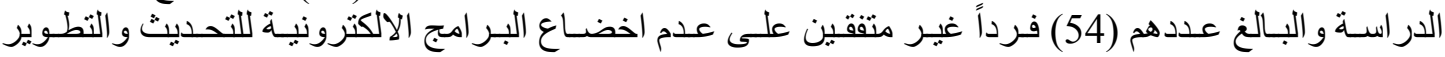

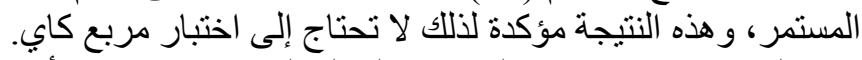

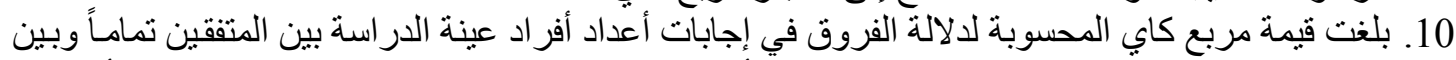

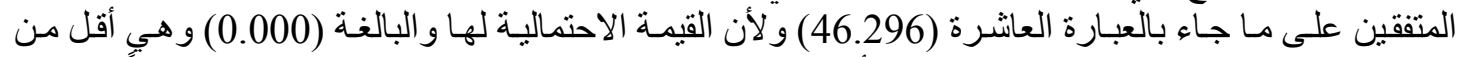

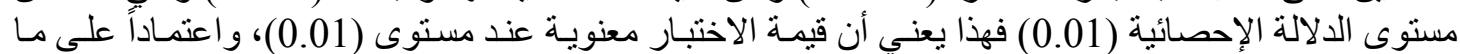

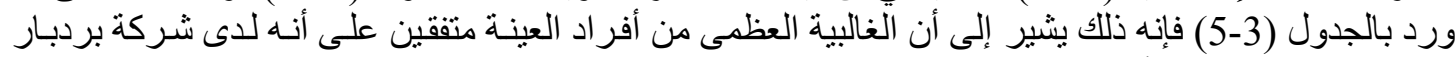

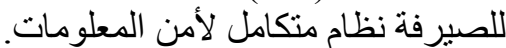

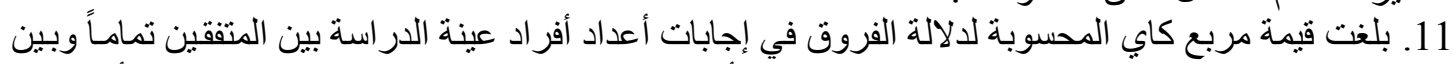

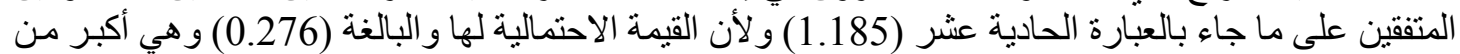

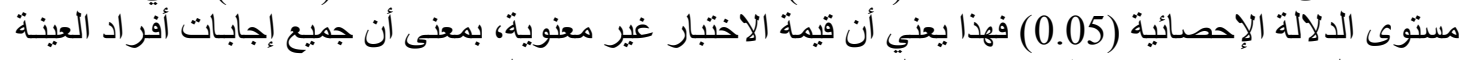

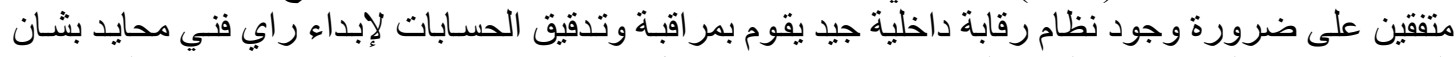

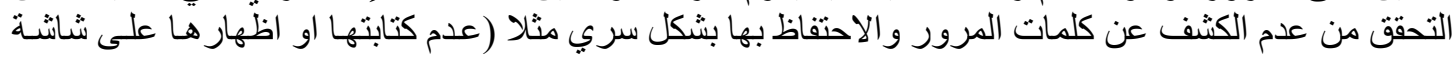

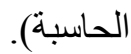

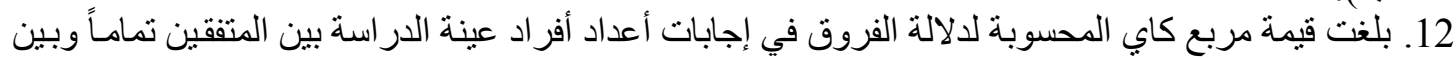

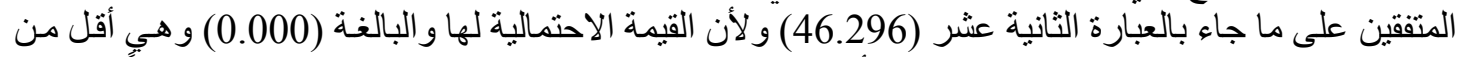

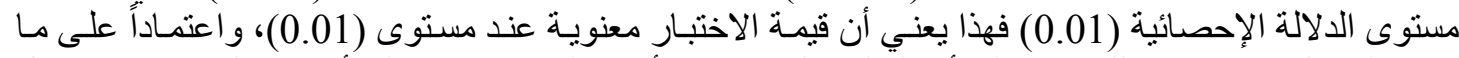

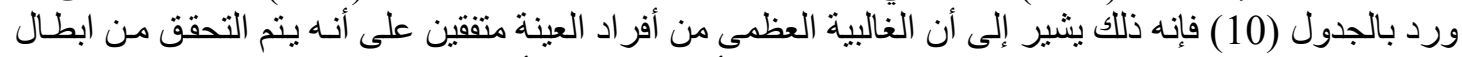

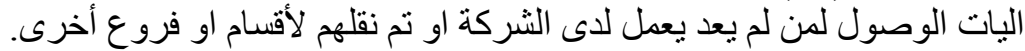

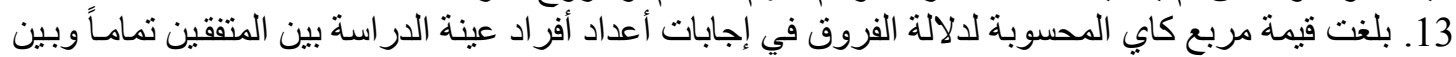

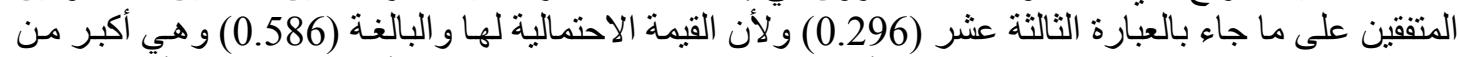

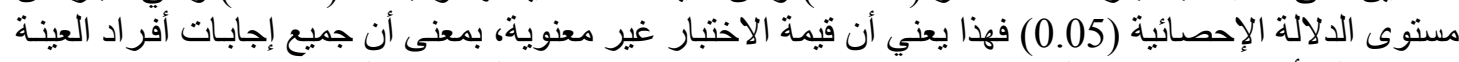

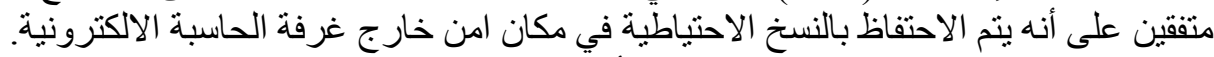

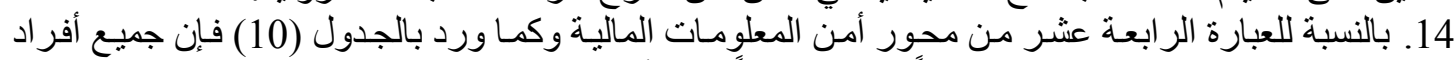

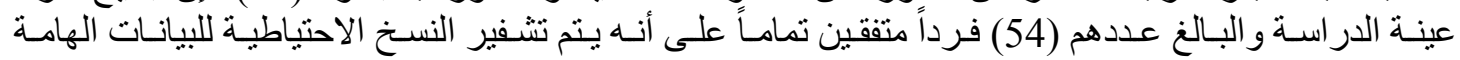
المحفوظة خارج غرفة الحاسبة الالكترونية.

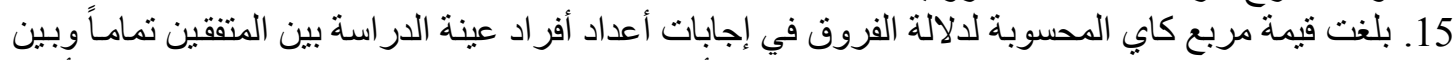

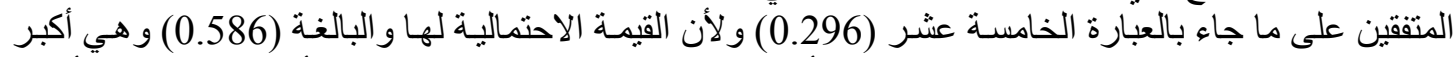

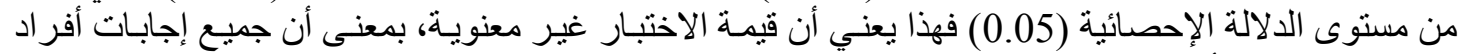

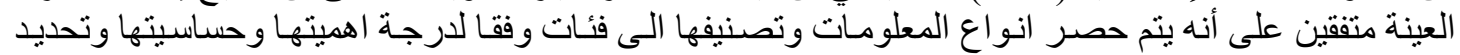

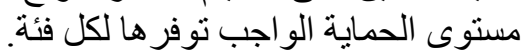

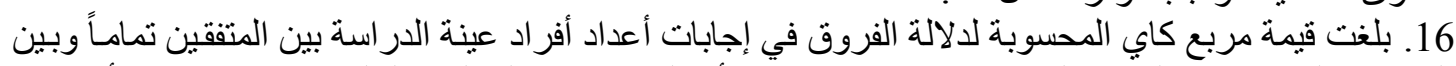

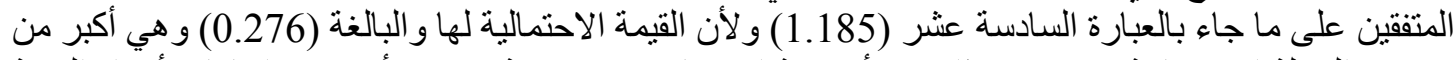

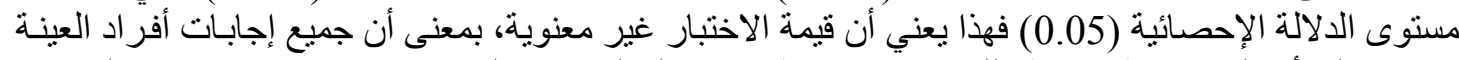

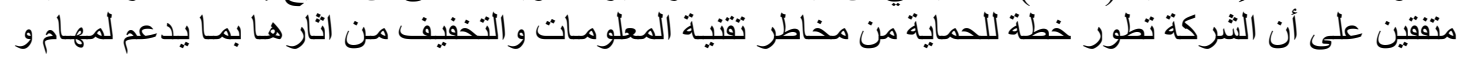

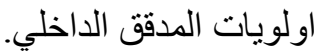

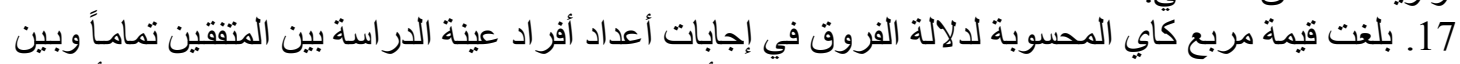

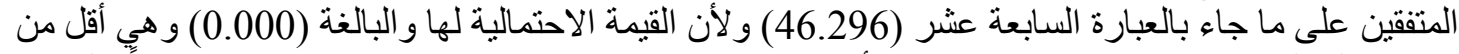

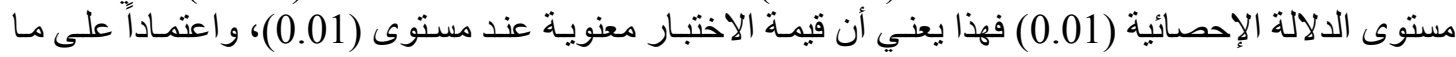




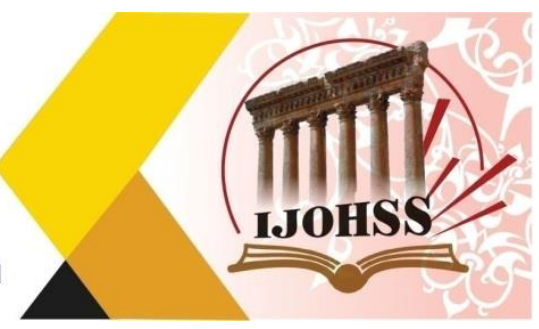

ورد بالجدول (10) فإنه ذللك يشير إلى أن الغالبية العظمى من أفر اد العينة متفقين على أنـه يتم الاشـر اف وتوزيع

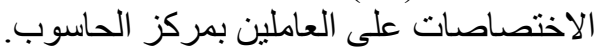

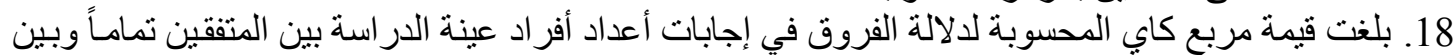

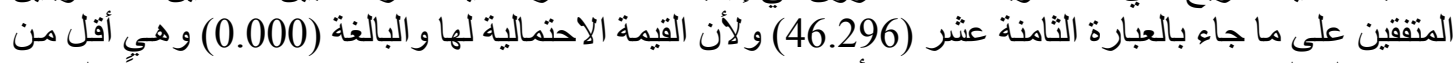

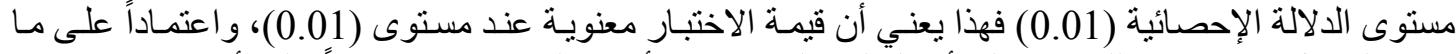

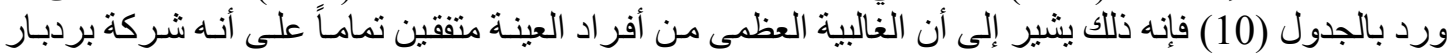

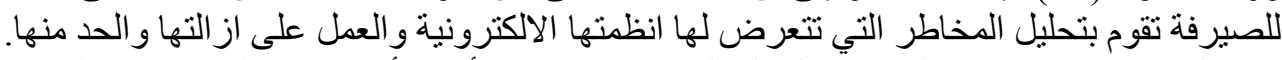

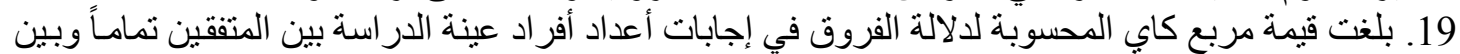

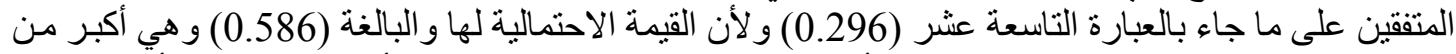

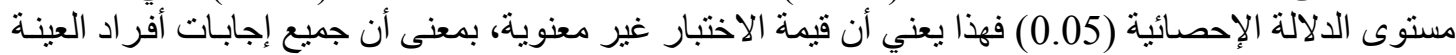

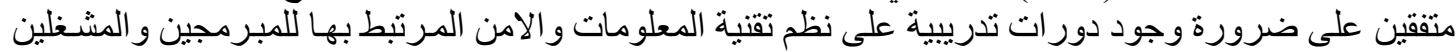
المستخدمين.

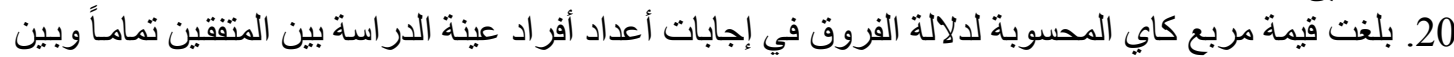

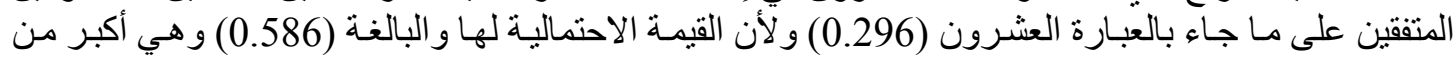

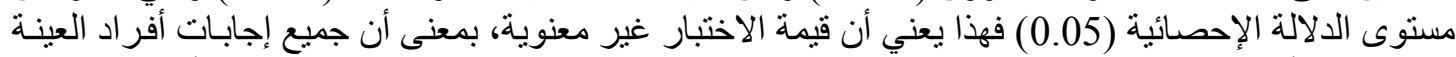

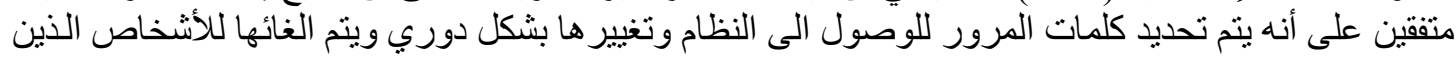
تركوا العمل في شركة بردبار للصيرفة.

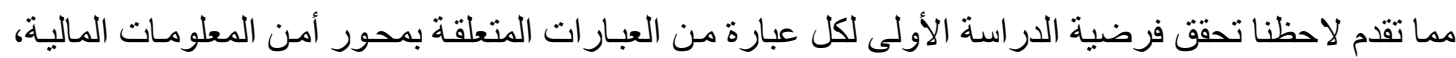

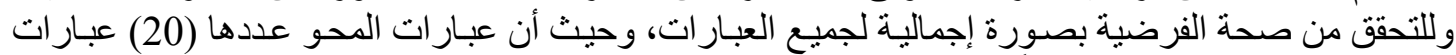

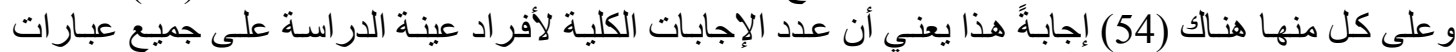

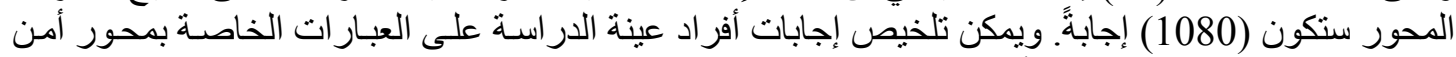
المعلومات المالية بالجدول (12) أدناه: وانكاه

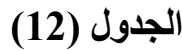

التوزيع التكراري لإجابات أفراد عينة الدراسة على جميع عبارات محور أمن المعلومات المالية

\begin{tabular}{|c|c|c|}
\hline النسبة المئوية & العدد & الإجابة \\
\hline$\% 36.7$ & 396 & أَتفق تماما \\
\hline$\% 45.8$ & 495 & أتفق \\
\hline$\% 12.5$ & 135 & محايد \\
\hline$\% 5.0$ & 54 & لا أتفق \\
\hline$=$ & - & لا أتفق تماماً \\
\hline$\% 100$ & 1080 & المجموع \\
\hline
\end{tabular}

- الجدول من إعداد الباحث بو اسطة البرنامج SPSS

التوزيع التكر اري لإجابات أفراد عينة الدر اسة على جميع عبار ات محور أمن المعلومات المالية

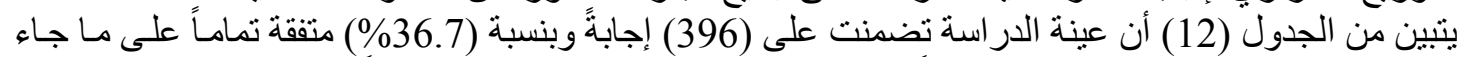

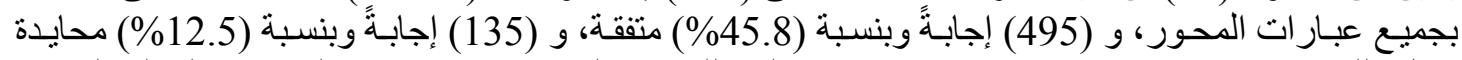

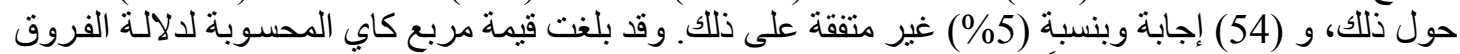

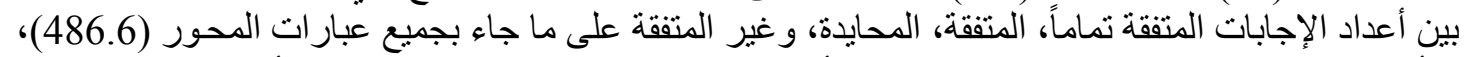

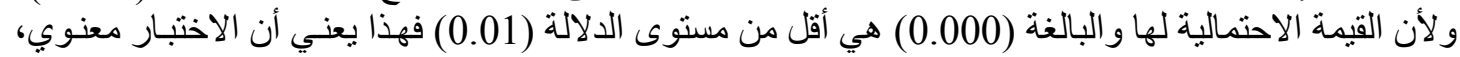




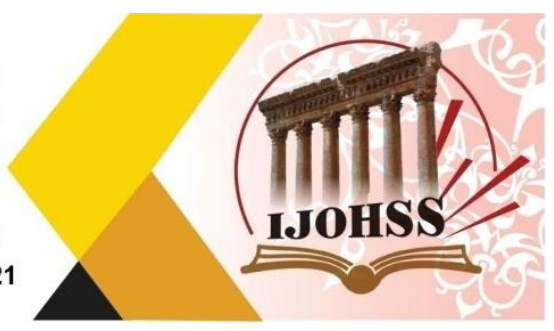

بمعنى هناك فروق ذات دلالة إحصائية و عند مستوى دلالة (1\%) بين الإجابات ولصالح الإجابات المتفقة على ما

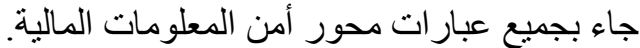

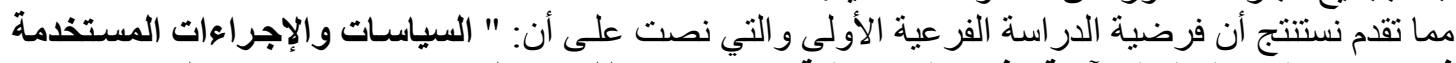

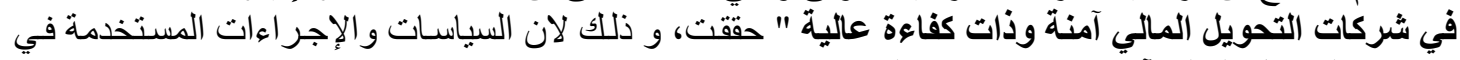

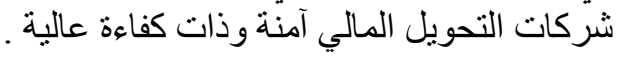

2-4-3 اختبار الفرضية الفرعية الثانية

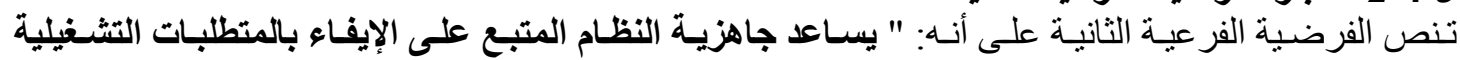

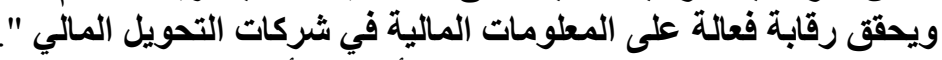

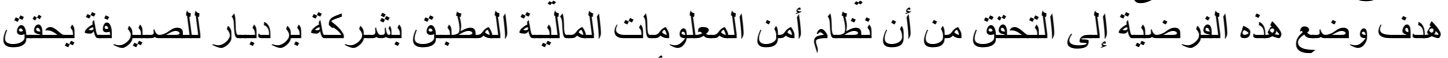

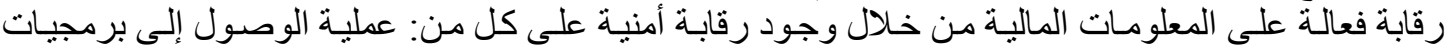

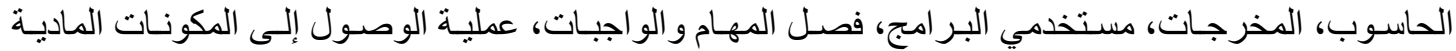

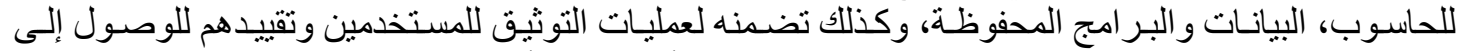

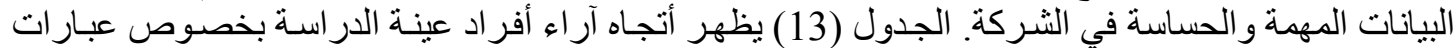
محور الرقابة على أمن المعلومات المالية.

(13) - الجدول

الوسيط لإجابات أفراد عينة الاراسة على عبارات محور الرقابة على أمن المعلومات المالية

\begin{tabular}{|c|c|c|c|}
\hline \multicolumn{2}{|r|}{ 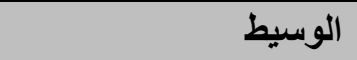 } & \multirow[b]{2}{*}{ 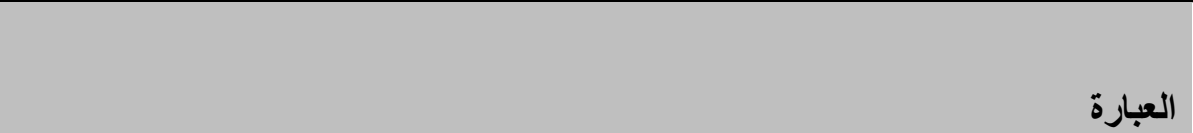 } & \multirow[b]{2}{*}{ ت } \\
\hline الإجابة & 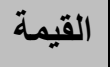 & & \\
\hline أتفق تماماً & 5 & توجد رقابة امنية على عملية الوصول الى برمجيات الحاسوب؟ & 1 \\
\hline 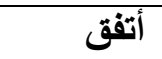 & 4 & توجد رقابة امنية على البيانات؟ & 2 \\
\hline أتقق & 4 & توجد رقابة امنية على المخرجات؟ & 3 \\
\hline أتفق تماماً & 5 & توجل رقابة امنية على مستخدمي البرامج? & 4 \\
\hline أتفق & 4 & توجد رقابة امنية على فصل المهام والواجبات؟ & 5 \\
\hline أتثق & 4 & توجد رقابة امنية متعلقة بالتجاوزات للوصول الطبيعي للحاسوب؟ & 6 \\
\hline أتفق تماماً & 5 & توجد رقابة امنية على عملية الوصول الى المكونات المادية للحاسوب؟ & 7 \\
\hline أتفق تمـامًاً & 5 & توجد رقابة امنية على البيانات والبرامج المحفوظة خارج جهاز تشغيلها؟ & 8 \\
\hline أتفق & 4 & يتم تقييا الموظفين المسموح لهم بالوصول الى البياتات المهمة والحساسة في الثركة؟ & 9 \\
\hline أتثقق تماماً & 5 & تثير امينين؟ سياسيات التوظيف الاطلاع على خلفيات الموظفين لتقليل احتمالية توظيف افراد & 10 \\
\hline أتقق & 4 & هنالك توثيق يظهر ان المستخدمين للأنظمة تم تدريبهم بشكل جيد. & 11 \\
\hline محايد & 3 & 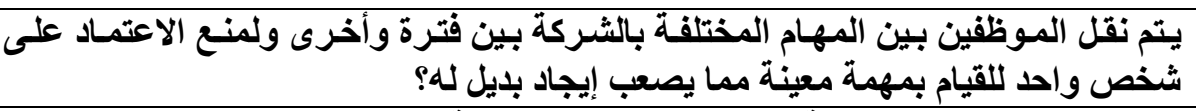 & 12 \\
\hline محايل & 3 & 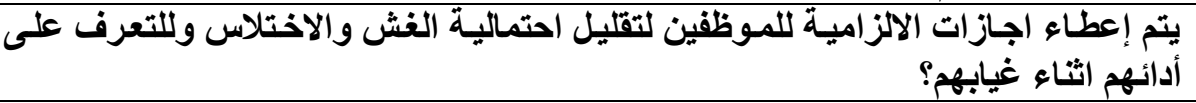 & 13 \\
\hline أتثق & 4 & ي عبار ات المحور & \\
\hline
\end{tabular}

ـ الجدول من إعداد الباحث بواسطة البرنامج 


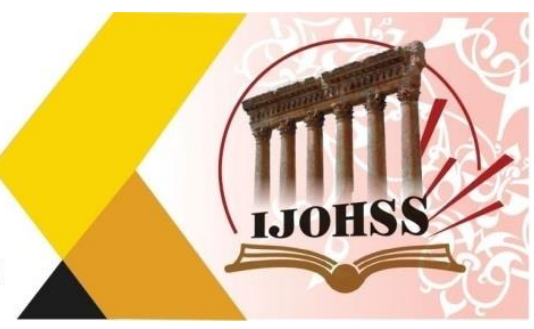

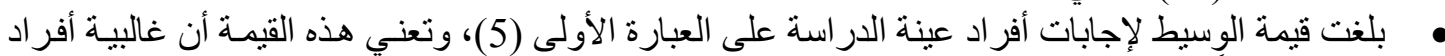

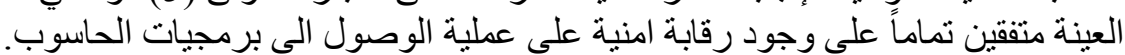

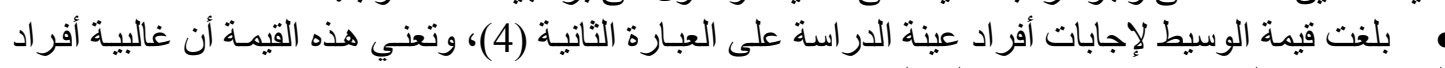
العينة متفقين على وجود رقابة العنية على البيات البيانات.

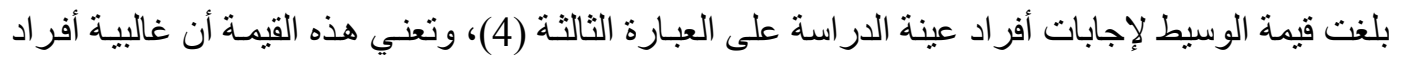

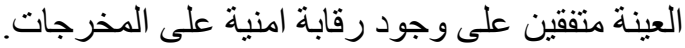

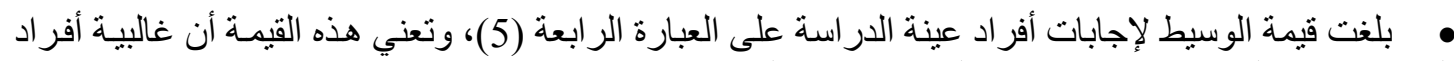

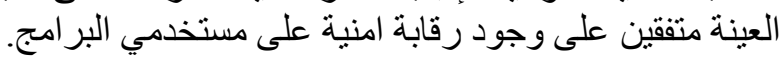

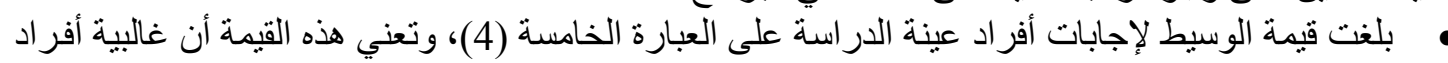

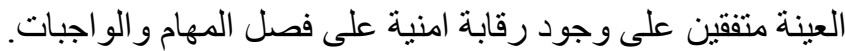

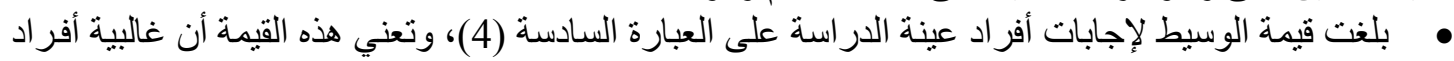

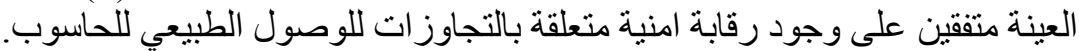

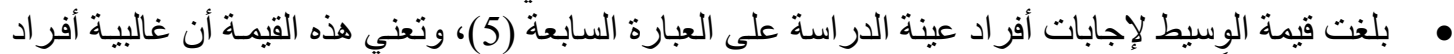

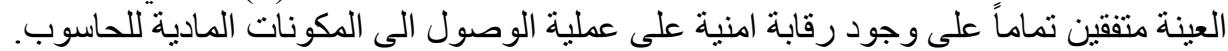

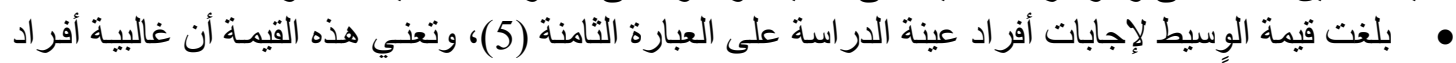

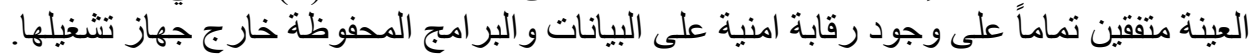

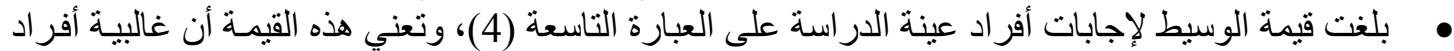

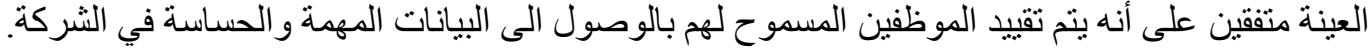

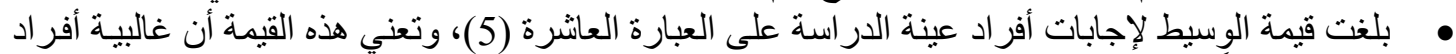

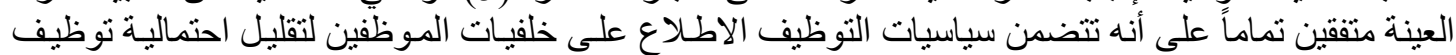

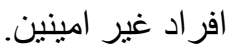

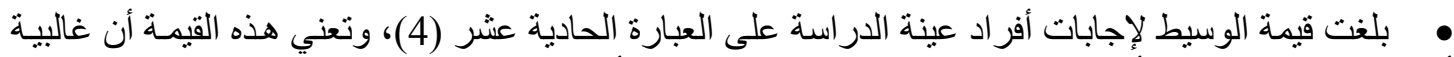

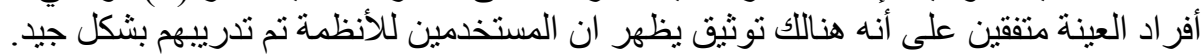

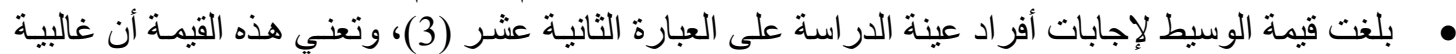

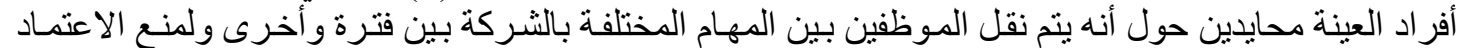

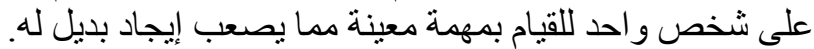

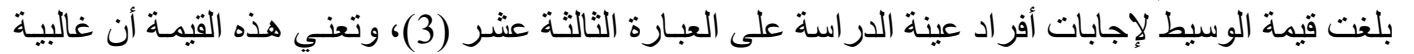

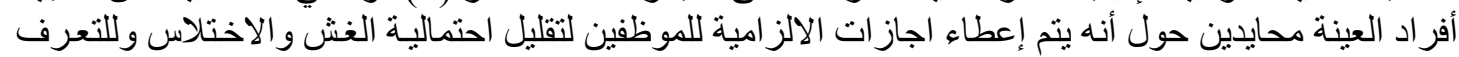

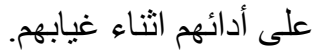

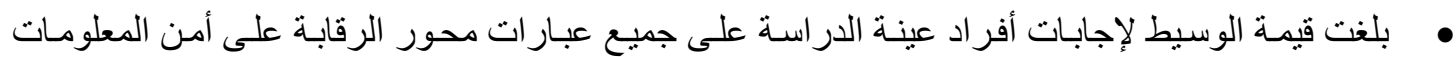
المالية (4)، وتعني هذه القيمة أن غالبية أفر اد العينة متفقين على مأ جاء بعبار ات هذا التهات المحور.

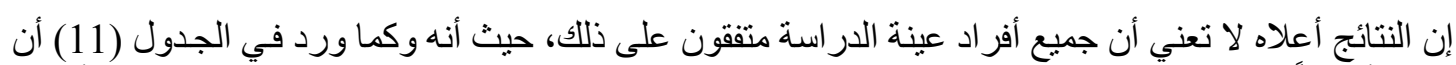

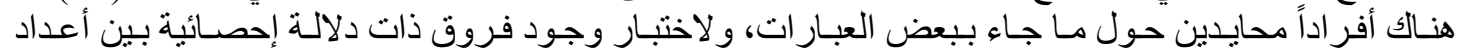

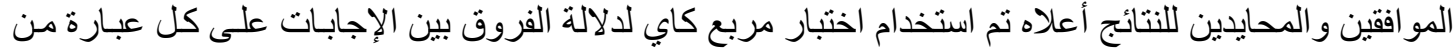
عبار ات محور الرقابة على أمن المعلومات المالية، الجدول رقم (14) يلخص نتائج الاختبار لهذه العبار التاتي 
المجلة اللحولية اللملوم الآسانية والإمتصاعية International Journal on Humanities and Social Sciences website:www.ijohss.com Email:editor@ijohss.com العدد (24) 2021 ISSN: $2415-4822$

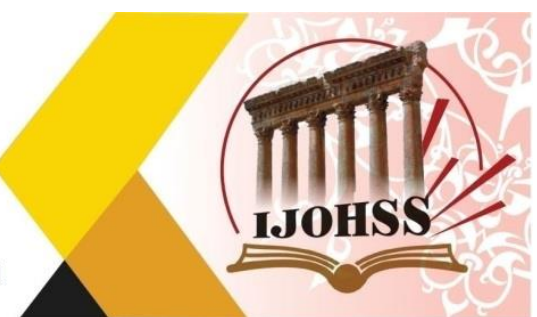

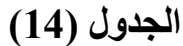

نتائج اختبار مريع كاي للفروق للإجابات على عبارات محور الرقابة على أمن المعلومات المالية

\begin{tabular}{|c|c|c|c|}
\hline Sig. & قيمـة مربــيع & 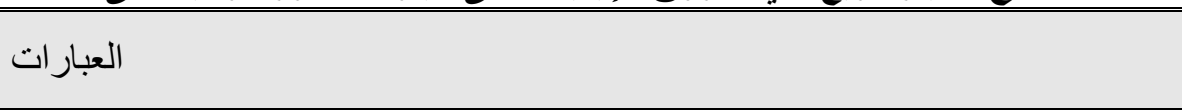 & $ت$ \\
\hline 0.000 & $46.296 * *$ & توجد رقابة امنية على عملية الوصول الى برمجيات الحاسوب؟ & 1 \\
\hline 0.000 & $50.074 * *$ & توجل رقابة امنية على البيانات؟ & 2 \\
\hline 0.000 & $25.444 * *$ & توجد رقابة امنية على المخرجات؟ & 3 \\
\hline 0.414 & 0.667 & توجد رقابة امنية على مستخذمي البرامج؟ & 4 \\
\hline-- & -- & توجد رقابة امنية على فصل المهام والواجبات؟ & 5 \\
\hline 0.000 & $25.444 * *$ & توجد رقابة امنية متعلقة بالتجاوزات للوصول الطبيعي للحاسوب؟ & 6 \\
\hline 0.000 & $24.778 * *$ & توجل رقابة امنية على عملية الوصول الى المكونات المادية للحاسوب؟ & 7 \\
\hline 0.000 & 24.778** & توجل رقابة امنية على البيانات والبرامج المحفوظة خارج جهاز تشغيلها؟ & 8 \\
\hline 0.000 & $46.296 * *$ & يتم تقييد الموظفين المسموح لهم بالوصول الى البيانات المهمة والحساسة في الثركة؟ & 9 \\
\hline 0.000 & $50.074 * *$ & 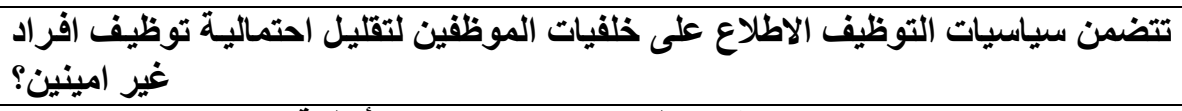 & 10 \\
\hline 0.585 & 0.296 & ـ هنالك توثيق يظهر ان المستخدمين للأنظمة تم تدريبهم بشكل جيد & 11 \\
\hline 0.000 & 70.778** & 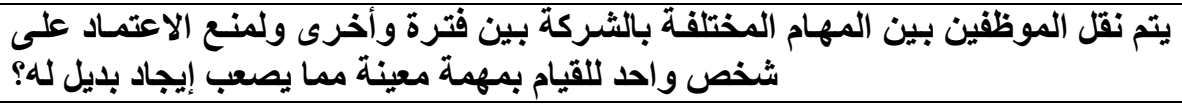 & 12 \\
\hline 0.000 & $18.111 * *$ & 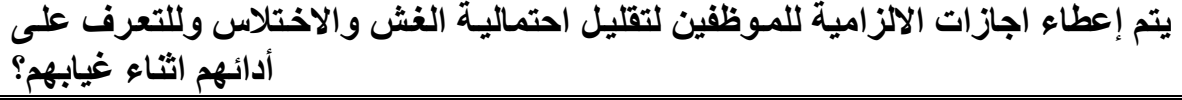 & 13 \\
\hline
\end{tabular}

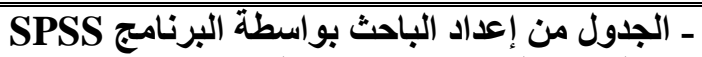

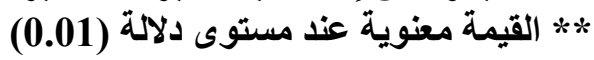

ويمكن تفسير نتائج الجدول أعلاه كالآتي:

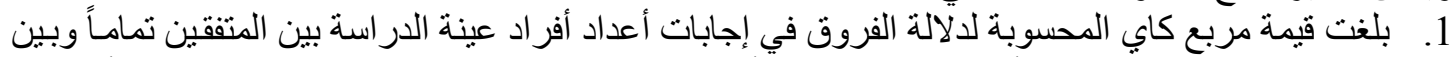

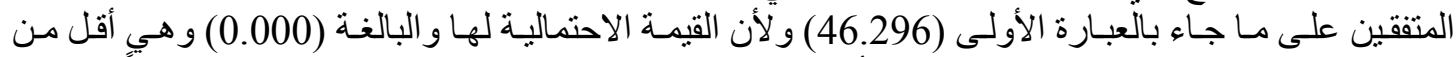

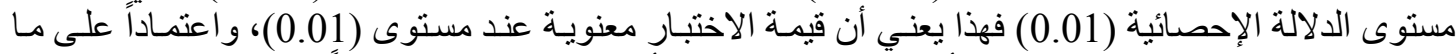

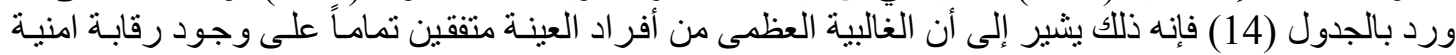

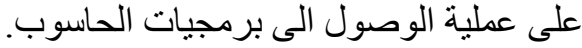

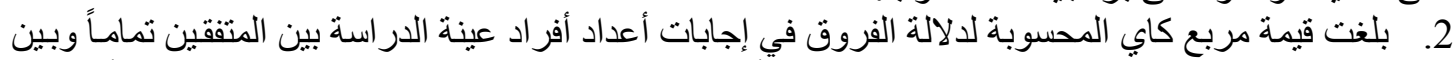

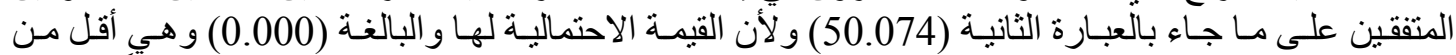

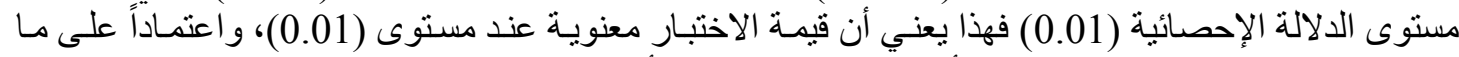

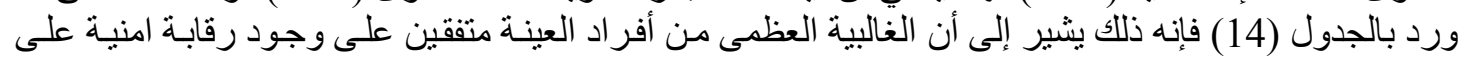
البيانات.

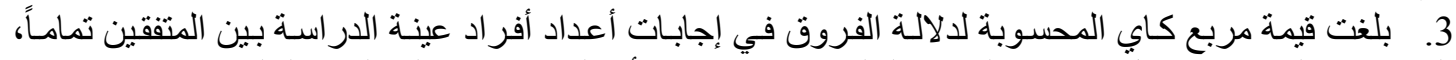

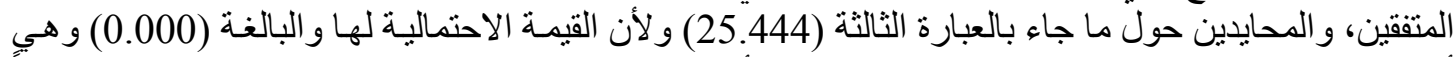
أقل من مستوى الدلالة الإحصـائية (0.01) فهذا يعني أن قيمـة الاختبـار معنويـة عند مستوى (254) (0.01)، و اعتمـاداً 


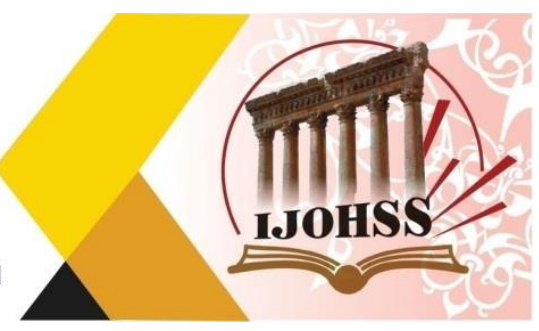

على ماورد بالجدول (14) فإنه ذلك يثير إلى أن الغالبية العظمى من أفر اد العينة متفقين على وجود رقابـة امنية

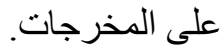

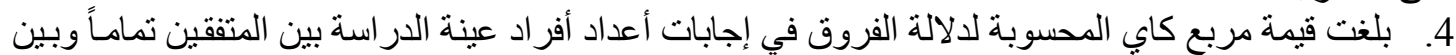

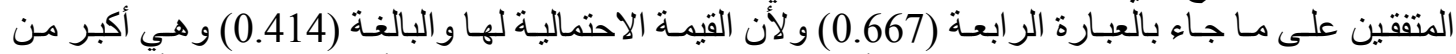

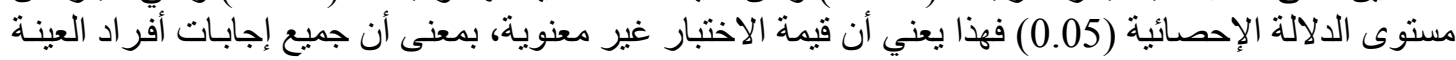

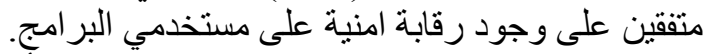

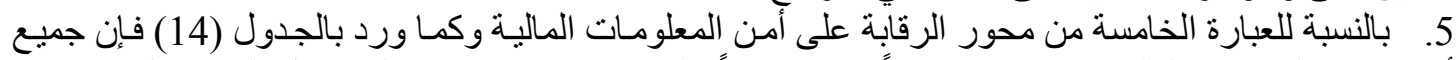

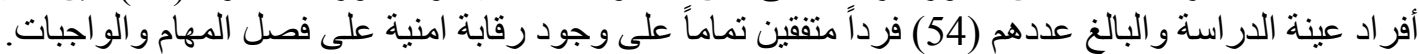

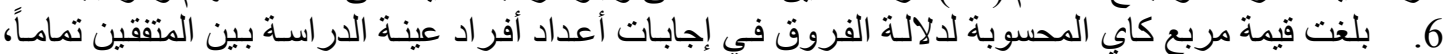

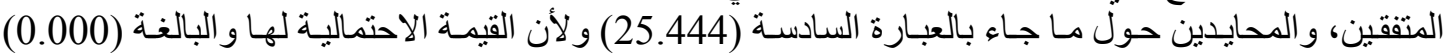

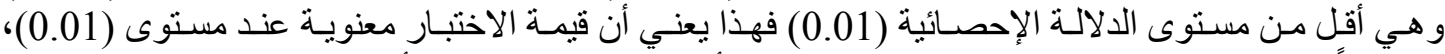

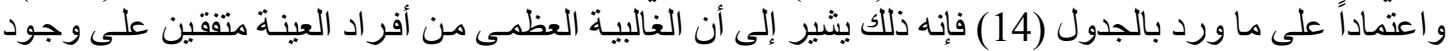

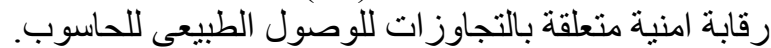

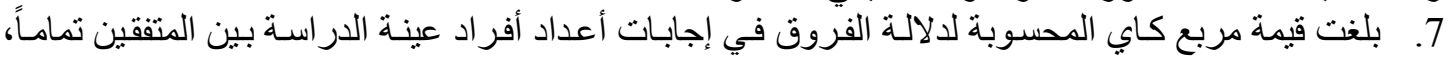

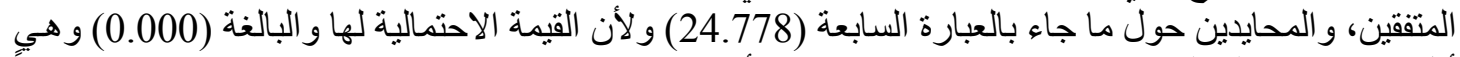

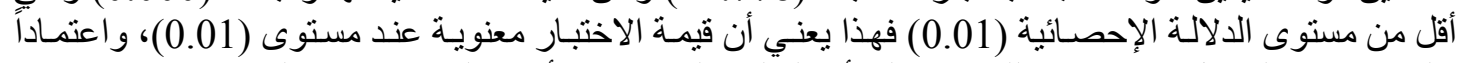

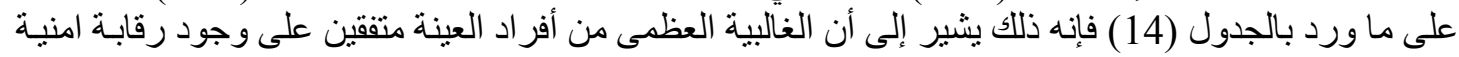
على عملية الوصول الى الئى المكونات المادية للحاسوب.

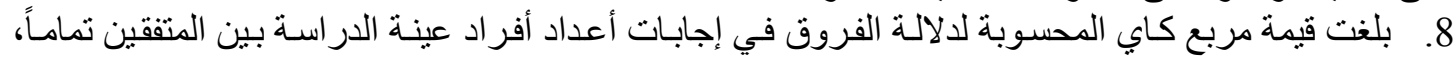

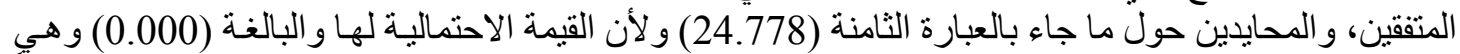

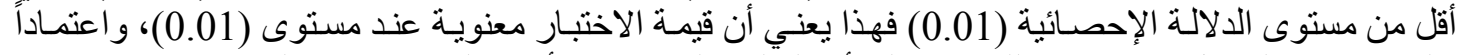

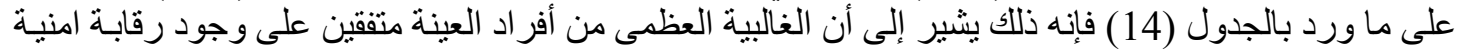

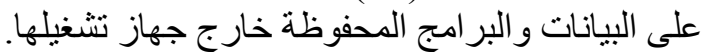

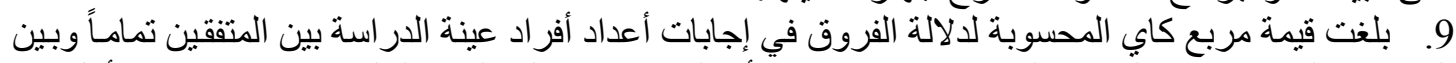

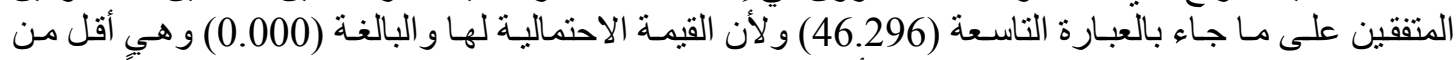

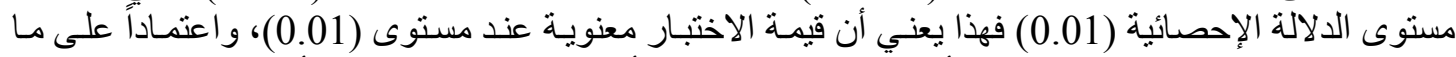

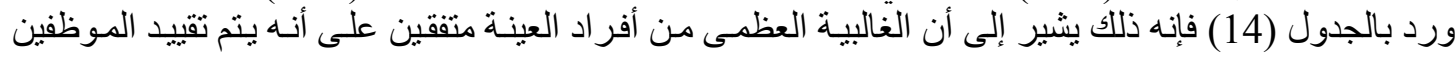

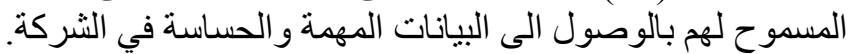

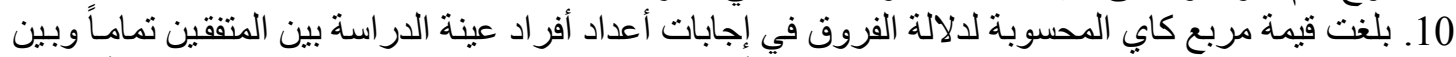

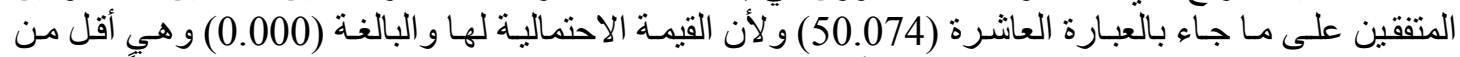

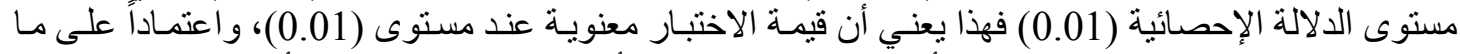

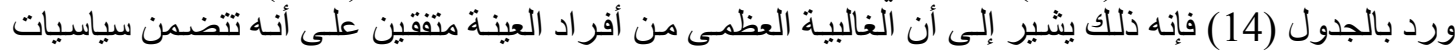

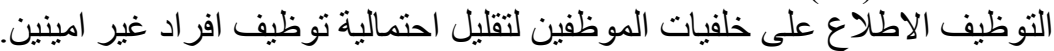

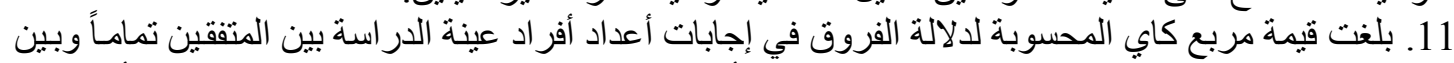

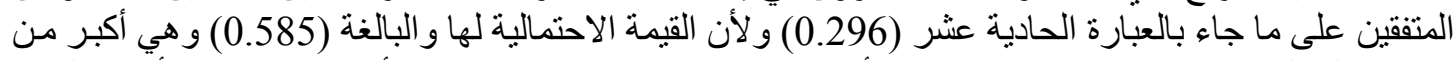

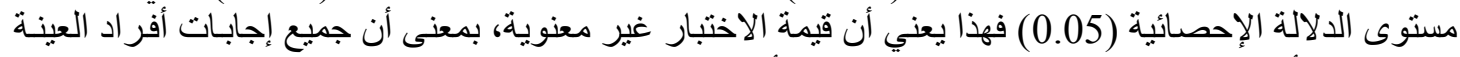

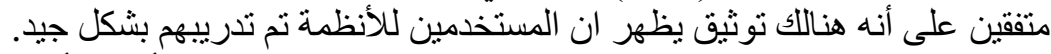

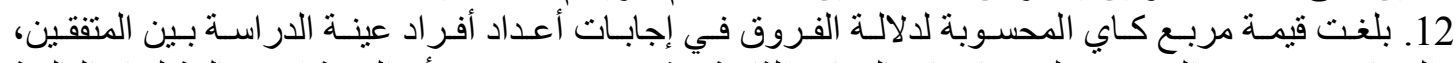

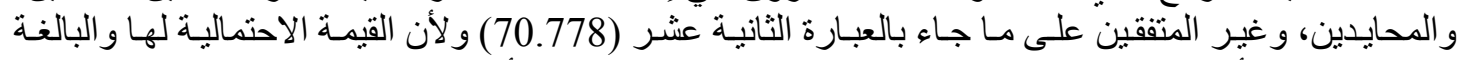

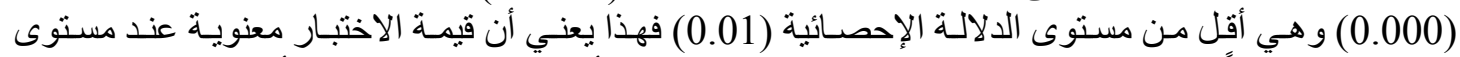

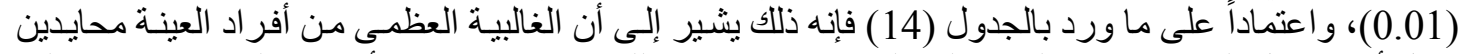

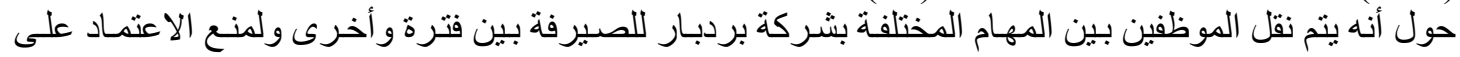

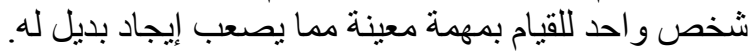




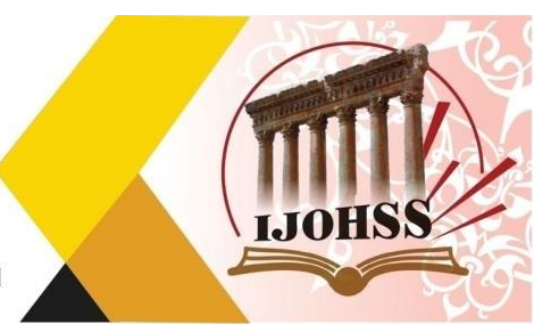

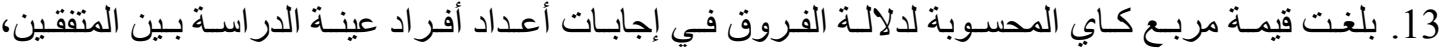

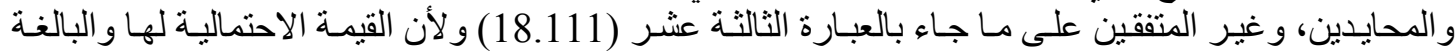

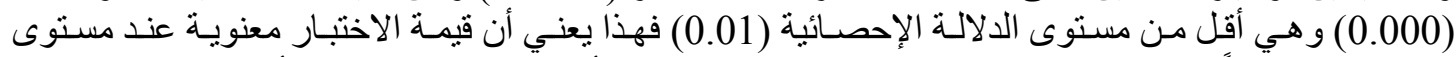

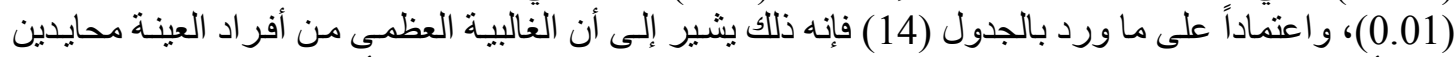

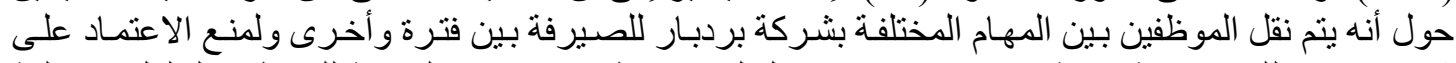

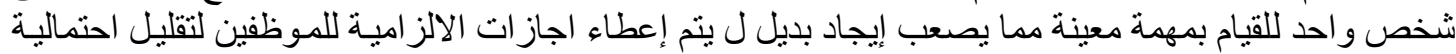
الغش و الاختلاس وللتعرف على على أدائهم اثناء غيابهر.

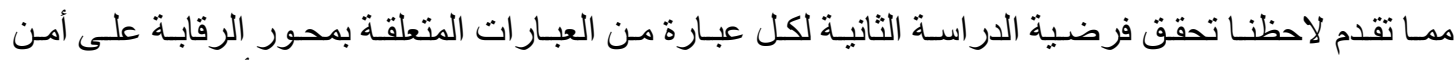

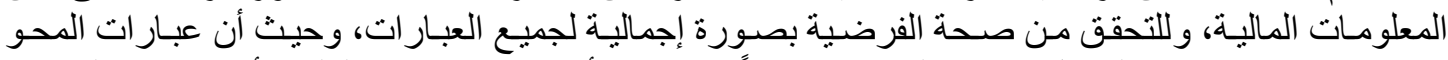

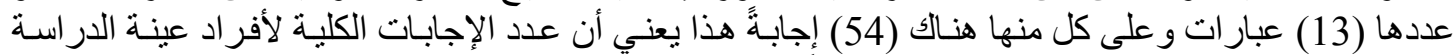

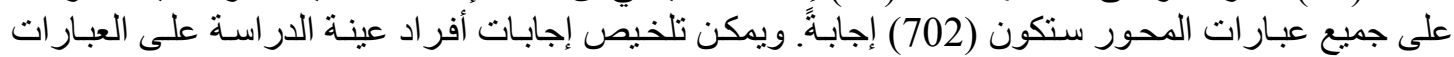
الخاصة بمحور الرقابة على أمن المعلومات المالية بالجدول (15) أدناه:

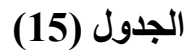

التوزيع التكراري لإجابات أفراد عينة الدراسة على جميع عبارات محور الرقابة على أمن المعلومات المالية

\begin{tabular}{|c|c|c|}
\hline النسبة المئوية & العدد & الإجابة \\
\hline$\% 31.8$ & 223 & أَتفق تماماً \\
\hline$\% 47.4$ & 333 & أتفق \\
\hline$\% 17.7$ & 124 & محايد \\
\hline$\% 3.1$ & 22 & لا أتفق \\
\hline$\ldots$ & - & لا أتفق تماماً \\
\hline \%100 & 1080 & المجموع \\
\hline
\end{tabular}

- الجدول من إعداد الباحث بواسطة البرنامج المباع

التوزيع التكر اري لإجابات أفر اد عينة الدراسة على جميع عبار ات محور الرقابة على أمن المعلومات المالية

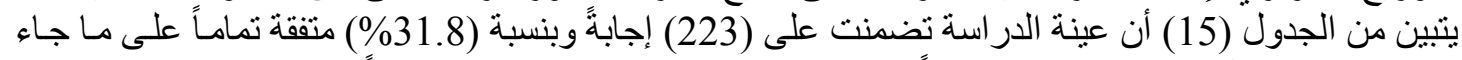

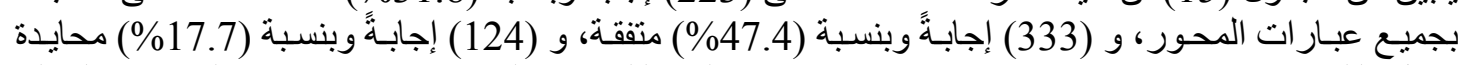

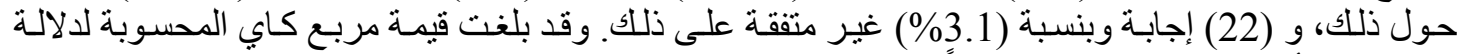

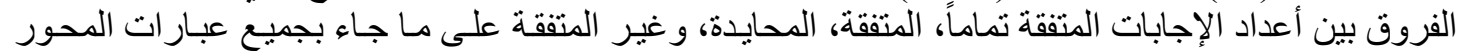

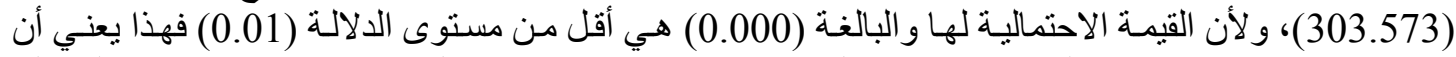

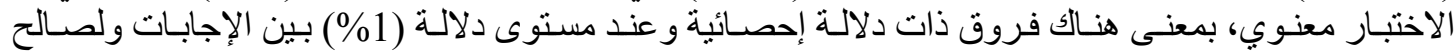

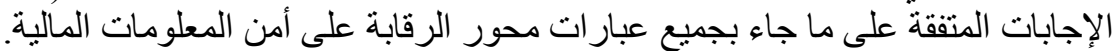

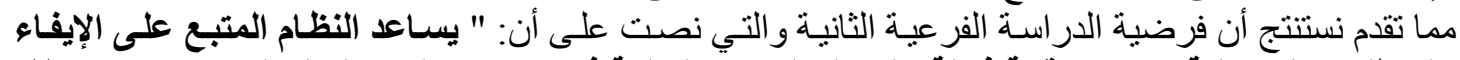

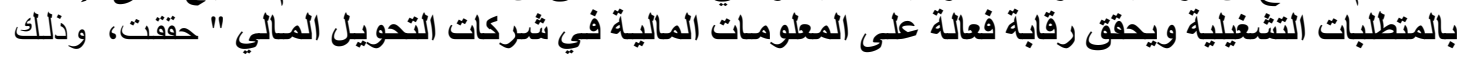

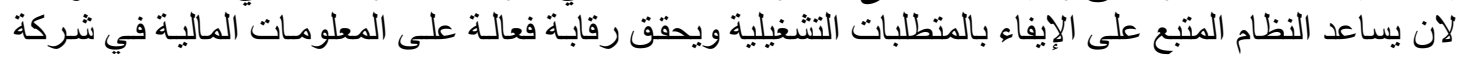
بردبار اللصيرفة.

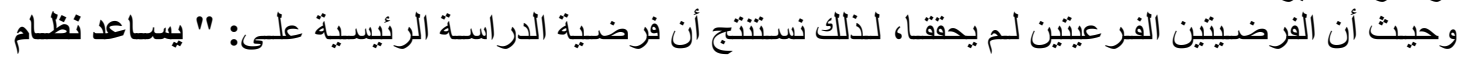

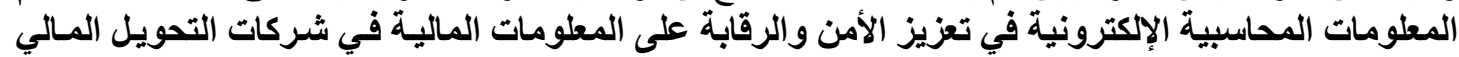
" 2قت. 


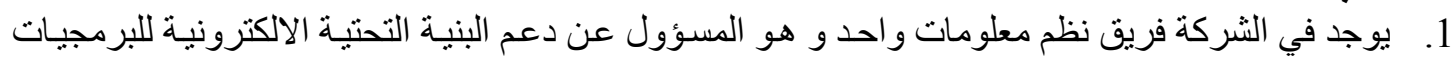

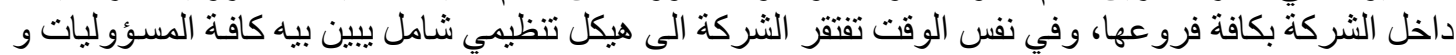
الو اجبات النتي يقوم بها الموظفين.

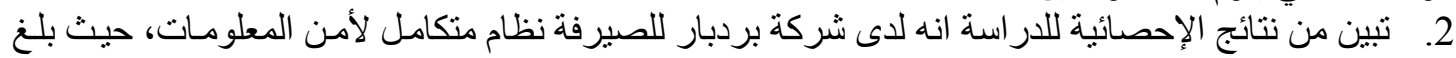

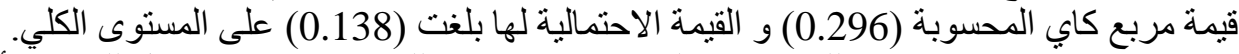

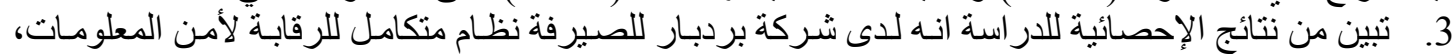

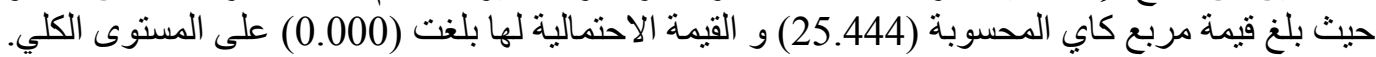

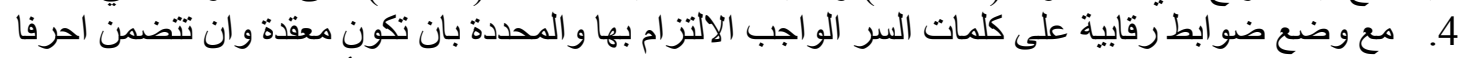

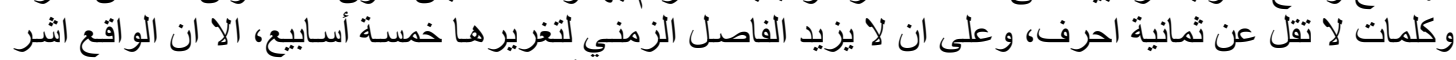

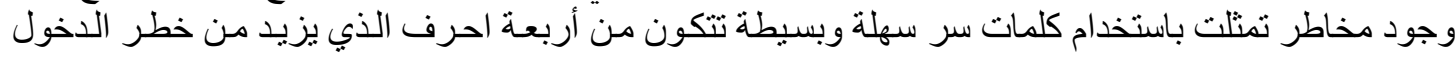

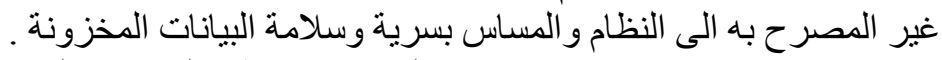

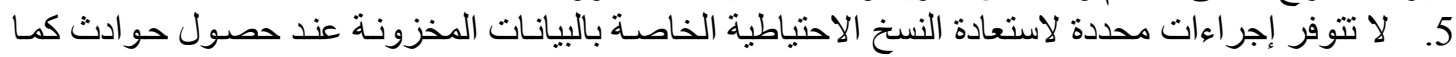

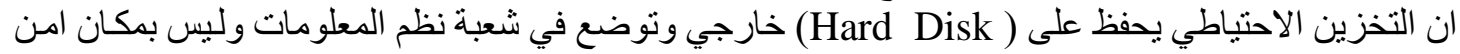

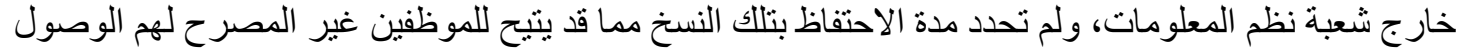
الى تلألك البيانات.

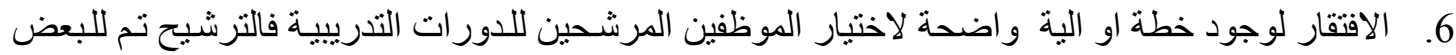

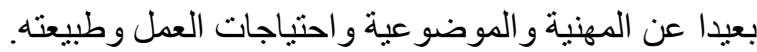

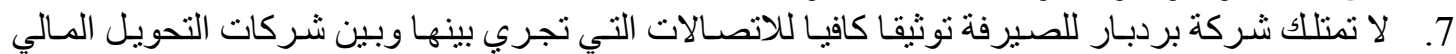

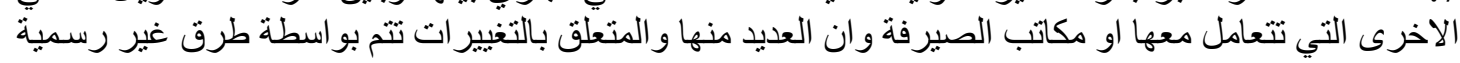

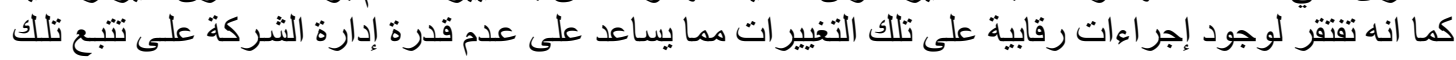

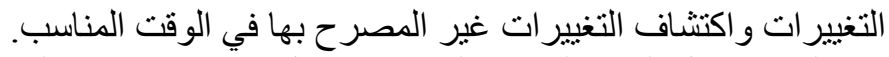

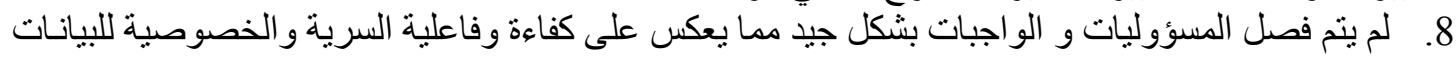

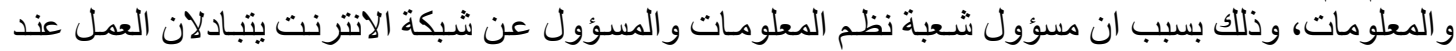

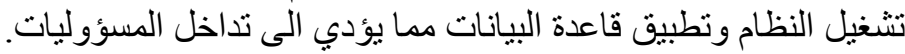

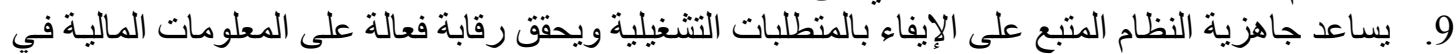
شركة بردبار للصيرفة.

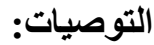
1. على شركة بردبار للصبرفة مر اعاة كافة البدائل للبر امج الموجودة المتعلقة بجانب الأمو ال و العمل المالي و

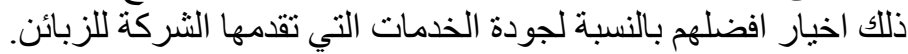

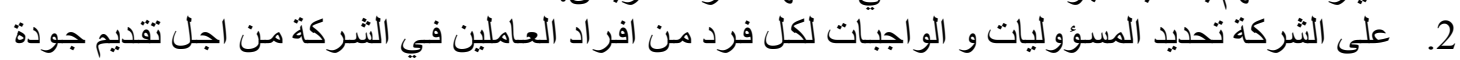

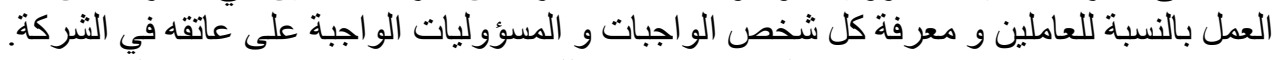

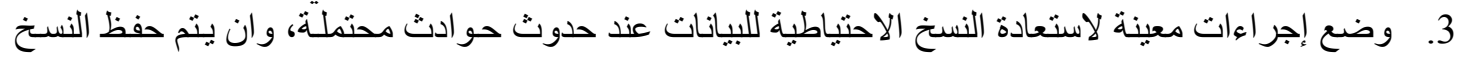

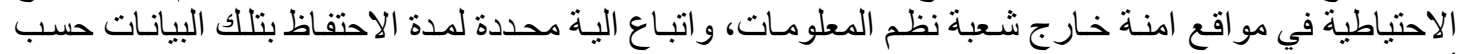

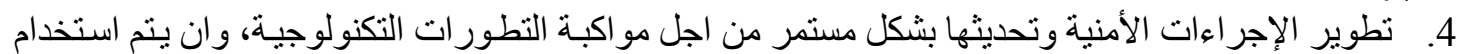

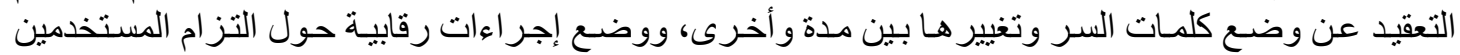

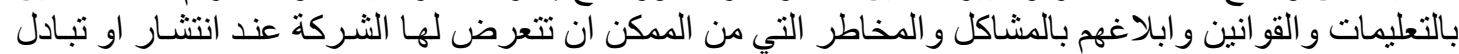

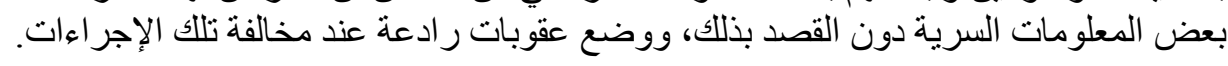




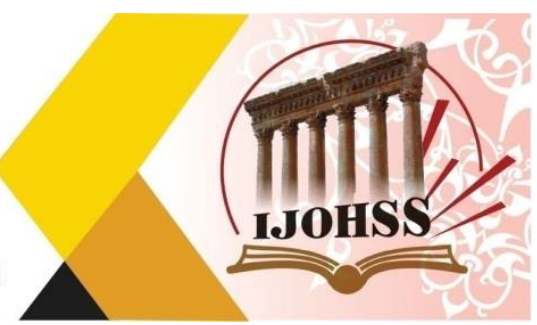

5. على الثركة توثيق الاتصالات التي تجري بين الثـركة وبين الأطر اف الأخرى المتمثلـة بشركات التحويل

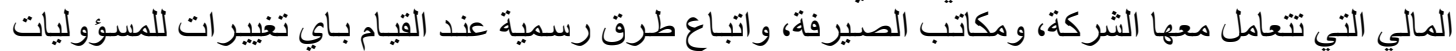

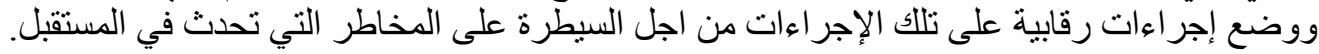

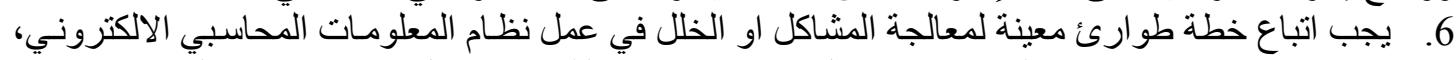

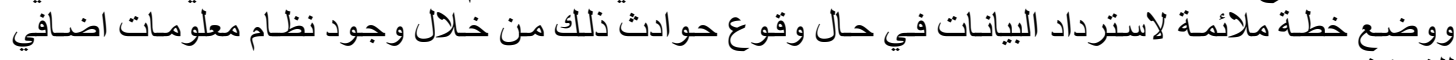
للشركة.

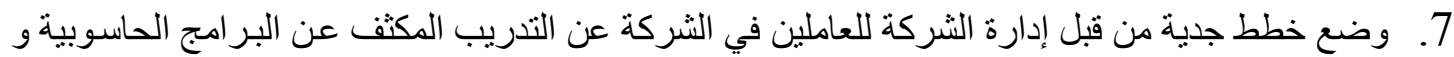

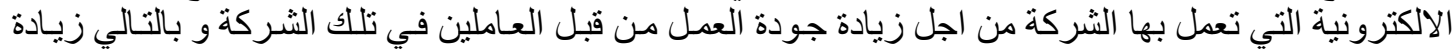
مستوى تقديم الخدمات المالية للزبائن.

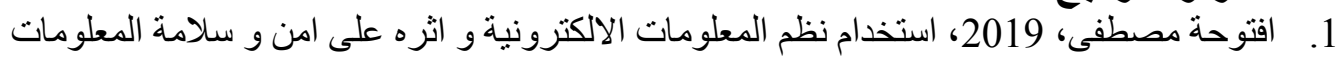

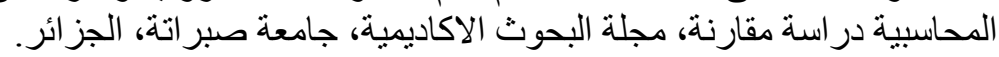

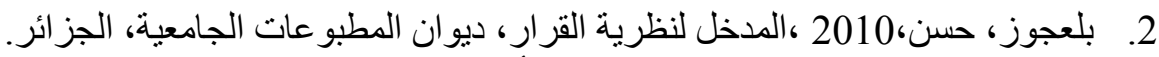

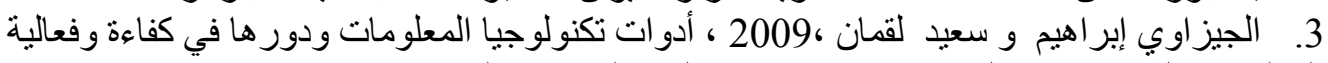

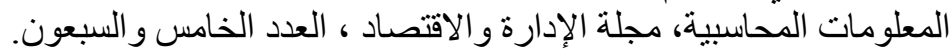

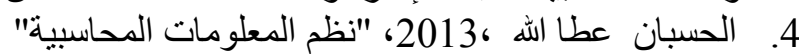

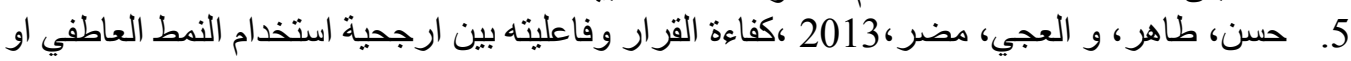

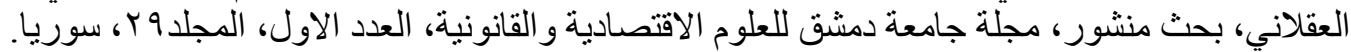

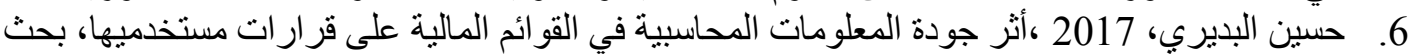

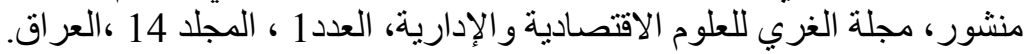
7.

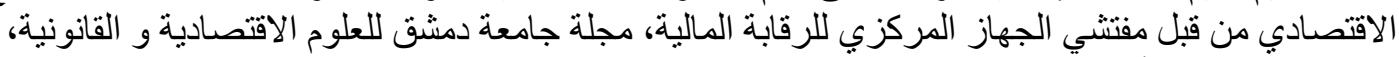
المجلد 26، العدد الأول، سوريا.

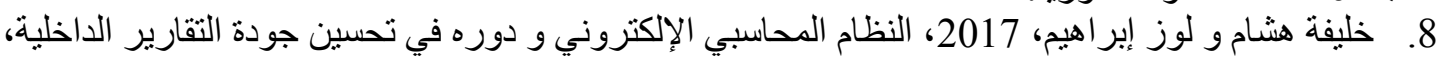

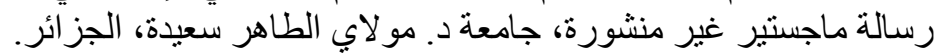

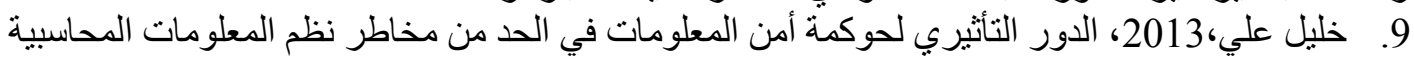

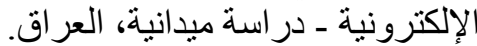

10. الدلاهمة، سليمان، 2011 ،اساسيات نظم المعلومات الرات المحاسبية وتكنولوجيا المعلومات، مؤسسة الوراق لاللنشر و التوزيع، عمان ، الأردن. 11. الزعبي منذر يحبى و اخرون، الأردن، 2009، رسالة ماجستير ، اثر استخدام نظم المعلومات المحاسبية على جودة

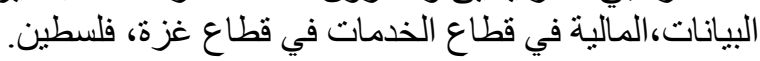
12. زمرة ،2013،دور التدقيق الداخلي في تحسين النظام المعلومات المحات فحاسبي، رسالة ماجستير غير منشورة،

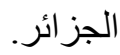

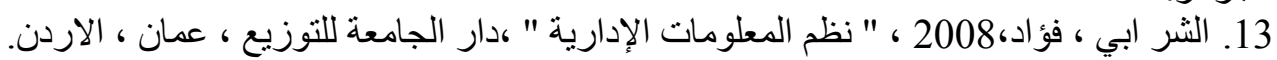

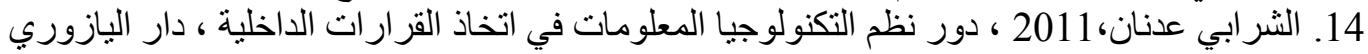

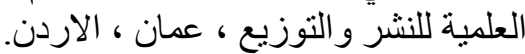

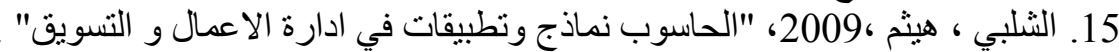
16. عامر قنديلجي و الجنابي،2005، مصادر المعلومات التقليدية والالكترونية، دار اليازوري الإلئية العلمية للنشر و التوزيع، عمان، الاردن.

17. العبيدي فاطمة، 2012، مخاطر استخدام نظم المعلومات المحاسبية المحوسبة و اثرها ها على فاعلية عملية التدقيق في ألأردن، رسالة ماجستير منشورة، جامعة شرق الأوسط، الأردن. 


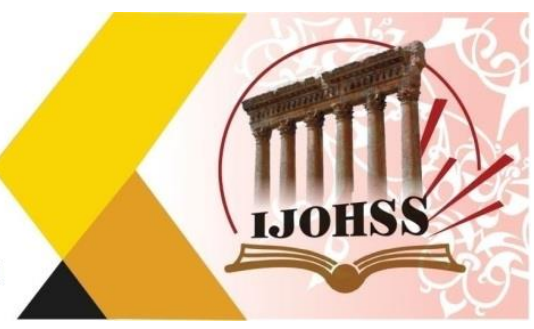

18. قويدر نز ار، 2018، نظم الرقابة الداخلية و اثر ها على امن المعلومات در اسة ميدانية على شركات المدار

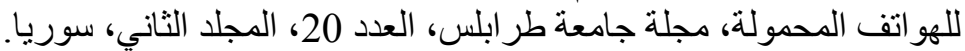
19. المصري تيسير و يوسف علي ،2012 ،نظم المعلومات المحاسبية، مركز التعليم المفتوح، جامعة دمشق، سوريا. 20. مصطفى عبد العزيز ،2008 ، استخدام الحاسب في التدقيق المالي والمراجعة ، كلية التجارة ، جامعة

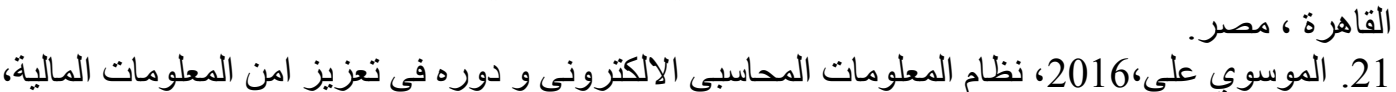

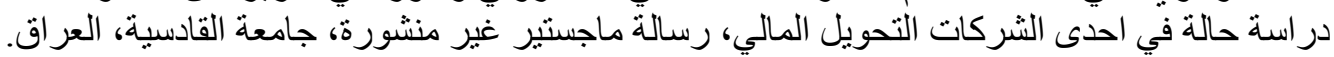

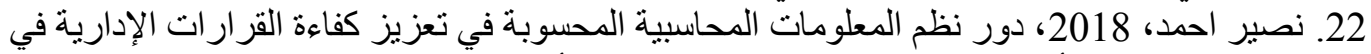
المستشفيات الجامعية الأردنية در اسة ميدانية، جامعة جدار المبار الما، الأردن.

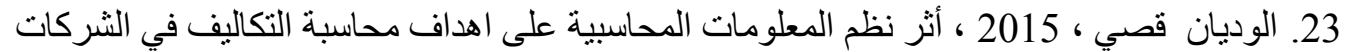

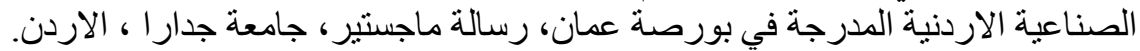

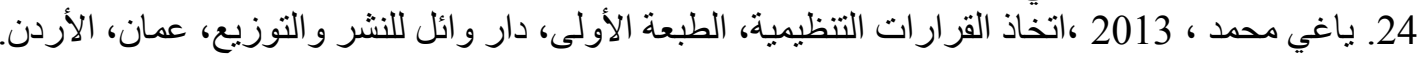
25. Francis,\&Olayemi 2016,Accounting Information System As Aids To Managerial Performances, 